\title{
VIII Congresso Mundial de Cirurgia Oncológica \\ VIII Congresso Brasileiro de Cirurgia Oncológica \\ V GASTRINCA \\ I Simpósio de Enfermagem em Cirurgia Oncológica
}

Data: 3 a 5 de Dezembro de 2009

Local: Windsor Barra Hotel \& Congressos

Rio de Janeiro - RJ

\section{RESUMOS}


Traquelectomia Radical Abdominal para

Tratamento do Câncer do Colo do Útero Invasor:

Relato de Caso

Freitas RR de, Roismann M, Britto JLC de, Hatschbach SBB, Linhares JC, Guerreiro JA,

Minari CL

Hospital Erasto Gaerner - Curitiba (PR), Brasil

Introduçáo: Desde a década de 1990, a traquelectomia radical - abdominal ou vaginal - tem sido palco de debates, a fim de preservar a fertilidade em pacientes com câncer do colo do útero. Apresentamos o caso de uma paciente com câncer do colo do útero tratada por traquelectomia radical abdominal. Relato do Caso: Paciente 33 anos, solteira, gesta I, para I, aborto 0 . Ao exame, carcinoma espinocelular do colo do útero, IB1. Indicada a cirurgia de Werthein Meigs. A paciente demonstrava o desejo de uma nova gestação. Proposta a traquelectomia radical abdominal como alternativa. A técnica consistiu em pesquisa de linfonodo sentinela, linfadenectomia pélvica bilateral, preservando os anexos. Estudo intraoperatório dos linfonodos sentinelas negativos. Realizou-se a ligadura da artéria uterina na origem, liberaçáo dos ureteres do paramétrio, identificação das fossas paravesical e pararretal, dissecção da vagina e dos paramétrios com secção dos mesmos. Incisáo do útero ao nível do ístimo e extirpaçăo da peça cirúrgica. Estudo intraoperatório negativo da margem superior do colo do útero. Sutura do corpo do útero à vagina. Paciente encontra-se em acompanhamento há três meses, sendo monitorada quanto à gravidez, momento em que será encaminhada ao serviço de gestação de alto risco referência. Conclusão: A traquelectomia radical abdominal permite resultados oncológicos comparáveis à cirurgia de Werthein Meigs. Ao mesmo tempo, apresenta uma menor curva de aprendizado em relação à cirurgia vaginal, oferecendo às pacientes com câncer do colo do útero a possibilidade de manter a fertilidade sem comprometer a cura. 1

\section{Fístula Anastomótica Pós-Esofagogastrectomia com Anastomose Intratorácica: Experiência do Hospital Erasto Gaertner /Curitiba}

\section{Freitas RR de, Valladares GCG, Kato M, Tomasich FDS, Targa GZ, Dias LAN} Hospital Erasto Gaertner - Curitiba (PR), Brasil

Introduçáo: A incidência de fístula pós-esofagogastrectomia com anastomose intratorácica na literatura representa $10 \%$ dos casos e está associada com uma mortalidade de $60 \%$. O inconveniente é a alta mortalidade nos casos que fistulizam. Objetivo: Descrever a incidência, as características e a terapêutica em fístulas anastomóticas intratorácicas pós-esofagogastrectomia no Hospital Erasto Gaertner. Pacientes e Métodos: Estudo entre 1999 e 2008 de 215 pacientes com câncer de esôfago, submetidos à esofagogastrectomia com anastomose intratorácica. Dessas cirurgias, 18 fistulizaram e representam a base deste trabalho. Resultados: De 215 anastomoses intratorácicas, $18(8,4 \%)$ fistulizaram. Dezesseis eram carcinoma epidermóide e dois adenocarcinoma. Dos 18 casos, $38,9 \%$ possuíam nível baixo de albumina e $27,8 \%$ eram desnutridos pelo IMC. Dez apresentaram fístula da anastomose, cinco necrose gástrica, dois fístula anastomótica associada à necrose gástrica e um não determinado o sítio. Dezessete pacientes foram conduzidos com tratamento cirúrgico da fístula e 1 com tratamento clínico. Dos casos tratados com cirurgia, 16 foram submetidos à esofagostomia cervical, gastrectomia, decorticação pulmonar e drenagem torácica, e um submetido à rafia com "patch" muscular. No momento do diagnóstico da fístula, dez estavam regulares e oito em mau estado geral. Dez $(55,6 \%)$ evoluíram a óbito e sete $(44,6 \%)$ sobreviveram ao tratamento cirúrgico da fístula. Conclusáo: A incidência da fístula torácica e a mortalidade pós-operatória mostraram-se inferior à literatura em nosso serviço. Os dados refletem a experiência de um centro especializado, resultando em uma melhor seleçáo de pacientes e a um tratamento cirúrgico precoce das complicaçōes.
Hemipelvectomia: Experiência do Hospital Erasto Gaertner com 32 Casos em Dez Anos

Freitas RR de, Crivellaro ALS, Mello GJP, Armani Neto M, Freitas Filho G de, Silva LV da Hospital Erasto Gaerner - Curitiba (PR), Brasil

Introdução: Os ossos pélvicos são sede de menos de $5 \%$ dos tumores ósseos malignos. Apesar de raras, essas neoplasias constituem um problema de difícil solução. Objetivo: Mostrar a experiência do Hospital Erasto Gaertner com as cirurgias de hemipelvectomias em um período de dez anos. Métodos: Estudo retrospectivo de 32 pacientes submetidos à hemipelvectomia de 1998 à 2008, avaliando características clinicocirúrgicas. Resultados: Oito casos apresentavam comprometimento de feixe vasculonervoso: três localizavam-se em ilíaco, dois em acetábulo e três em acetábulo e púbis. Vinte e três apresentavam o feixe vásculo nervoso livre de neoplasia e um comprometimento de vasos ilíaco-femorais. Sete casos de condrossarcoma e quatro de sarcoma de Ewing representaram a maioria. Oito foram submetidos à hemipelvectomia externa e 24 à hemipevectomia interna (11 tipo I; 6 tipo II; 4 tipo III; 3 tipo IV) . Destes 24 casos, 13 sem reconstrução, dez com enxerto de fíbula e um com prótese de veia e artéria ilíaco-femorais. Vinte e seis cirurgias foram curativas e seis paliativas. Ocorreram 14 óbitos. Sobrevida de dois e cinco anos observada em 11 e dez casos, respectivamente. Conclusão: Os dados mostram a experiência de um serviço de referência em oncologia, especializado no tratamento de cirurgias de alta complexidade.

\section{A Edição de Livros Técnico-Científicos no INCA}

Facina TF, Moraes MCCP, Oliveira MHR Instituto Nacional de Câncer (INCA), Rio de Janeiro (RJ), Brasil

Introduçáo: O Instituto Nacional de Câncer publica livros técnicocientíficos e educativos a serem utilizados para a produção do conhecimento em saúde e a disseminação de informaçôes dessa área, em consonância com a Rede de Atenção Oncológica. Publicaçôes essas que passam por um amplo processo editorial, que tem a responsabilidade de transformar as informaçôes em produtos editoriais de qualidade. Objetivos: A gestão editorial do INCA atua para que essas informaçóes sejam disponibilizadas com qualidade, transparência e amplo acesso, zelando pelo alinhamento da obra às diretrizes do Instituto e à Política Editorial do Ministério da Saúde, pelo planejamento dos recursos e prioridades, e respeitando a legislação específica em vigor e os padrōes nacionais e internacionais de aceitação (normas da ABNT, catalogação, ISBN). Material e Métodos: A edição das publicaçōes passa por diversas etapas, entre diferentes equipes de profissionais no Serviço de Edição e Informação Técnico-Científica/Coordenação de Educação, que compreendem: aprovação do Comitê Editorial, edição, preparação de texto/copidescagem, revisão gramatical, revisão das referências, projeto gráfico, diagramaçấo, produção de ficha catalográfica e pedido de ISBN, acompanhamento da produção gráfica, revisão da diagramação, revisão da boneca enviada pela gráfica, distribuição e expedição. Conclusáo: É essencial que os livros técnico-científicos e/ou educativos do INCA passem por um processo editorial, pois este garante produtos editoriais de qualidade, cumprimento de normas, facilita o amplo acesso à informaçáo e garante que as obras editadas pelo INCA cumpram os requisitos básicos da recuperaçáo da informaçáo em bases de dados. 


\section{Changing Surgical Strategies after Imatinib Neoadjuvant Therapy: Case Report}

Cesar D, Graziosi G, Valadão M, Linhares E, Costa B, Muharre R Bonsucesso General Hospital Surgical Department - Rio de Janeiro (RJ), Brazil

Imatinib is currently under clinical investigation for use in neoadjuvant setting for patients with large tumors or metastasis. A 60-year-old man complaining of a dragging sensation in the rectum and several episodes of pelvic pain. Digital investigation revealed a mass about $2.0 \mathrm{~cm}$ above the dentate line. Colonoscopy and CT showed tumor in lateral left wall of the lower third of the rectum, and no evidence of metastasis. CEA and CA 19-9 were normal. Patient underwent an abdomino-perineal resection (APR). Immunohistochemical confirmed spindle-cell GIST, by investigation. Both CD117 and CD34 were extremely positive and the mitotic index was $<5 / 50$ HPF. Resection margins were negative. Patient did not undergo adjuvant therapy with imatinib. After 24 months of follow-up, he initiated complaints over uninterrupted pelvic pain not associated with weight loss, GI bleeding or vomiting. CT showed a large and irregular pelvic mass. Patient was ruled on neoadjuvant therapy with Imatinib mesylate $400 \mathrm{mg}$ per day during three month period. New CT revealed significant tumor shrinkage and no distant metastasis. Patient was submitted to exploratory laparotomy with resection of cystic, fibroelastic mass, located in the right isquio-rectal fossa. He was discharged after 4 days with oral imatinib $400 \mathrm{mg}$ per day. The ability of imatinib to induce significant reductions in tumor size and to control overtly malignant metastatic disease in most patients with advanced GIST may expand opportunities for surgeons to treat more GIST patients, decrease the incidence of postoperative GIST recurrence, and thereby extend lives, as shown in this case report.

Sarcoma de Vagina: Relato de Um Caso

Gomes CHR, Costa LF, Stuart JM, Oliveira JG, Ramos MIA, Silva JA Fundação de Saúde Dilson de Quadros Godinho - Montes Claros (MG), Brasil

Introduçáo: As neoplasias primárias de vagina são consideradas doenças raras. Correspondem a cerca de $1-3 \%$ das neoplasias do trato genital feminino, sendo que, deste total, cerca de $90 \%$ são constituídas por carcinomas de células escamosas. Os sarcomas representam cerca de 1\% das neoplasias desse órgão, sendo menos comuns que adenocarcinomas e melanomas. Dos sarcomas, o tipo histológico mais encontrado é o leiomiossarcoma. Objetivo: Apresentar raro caso de sarcoma de vagina conduzido em nosso serviço. Métodos: Análise de prontuários e revisão de literatura. Relato do Caso: Trata-se de paciente de 57 anos. Realizava exames ginecológicos preventivos de rotina, tendo sido o último há nove meses, sem alteraçóes. Apresentava há três meses dor pélvica, sangramento vaginal pós-coito, disúria com piora progressiva e infecçấo urinária de repetição. Exame especular mostrou lesão ulcerada de cerca de $8 \mathrm{~cm}$ acometendo a vagina anterior e lateralmente. Biópsia revelou leiomiossarcoma de alto grau. Cistoscopia com dificuldade de progressão por aparente compressão externa, mas com mucosas de uretra e bexiga normais. Estadiamento préoperatório negativo para metástases Paciente foi submetida à exenteração pélvica anterior por acometimento do trígono vesical, com reconstrução à Bricker. Evoluiu sem intercorrências, sendo encaminhada para adjuvância posteriormente. Exame anatomopatológico mostrou ressecção R0 com estadiamento pT4N0M0. Conclusáo: A paciente realiza avaliaçóes periódicas sem sinais de recidiva até o momento.
The Importance of Clinical Suspicion on the Diagnosis and Treatment of Hereditary Colorectal Cancer

Cesar D, Graziosi G, Valadão M, Leal RA, Muharre RJ Bonsucesso General Hospital Surgical Department - Rio de Janeiro (RJ), Brazil

Colorectal cancer is the most frequent cancer in gastrointestinal tract and its incidence has increase over the last years. Approximately $80 \%$ of patients develop sporadic colorectal cancer and in $20 \%$ of patients there is a hereditary suscebility. A 40-years-old healthy white man with palpable mass and pain in right lower abdominal quadrant. In familial history he had a father and a brother who died of colon cancer. Computed tomography (CT) scan of abdomen showed a mass in right colon. Colonoscopy revealed a protrusive vegetant tumor on right colon, biopsy result was moderateddifferentiated adenocarcinoma. The patient underwent to laparoscopic right hemicolectomy. TNM stage was pT3N2M0 G2 (Stage IIIC). Adjuvant chemotherapy with 5-FU and Leucovorin was performed for 6 months. In the end of treatment the patient develops hematoquezia and abdominal pain. He was readmitted and the colonoscopy showed a ulcerated circumferential tumor situated $10 \mathrm{~cm}$ from the anal verge. Biopsy result was well differentiated adenocarcinoma. Neoadjuvant radiochemotherapy was performed. After two months he underwent laparotomy, rectal tumor invading the bladder and the seminal vesicles was visualized. Total proctocolectomy, pelvic exenteration, ileal pouch-anal anastomosis, loop ileostomy and Bricker urinary reconstruction was performed. TNM stage was pT4N2M0 G2 (Stage IIIC). Patient is now under Xelox protocol adjuvant chemotherapy. Cancer prevention, particularly among patients with familial adenomatous polyposis and hereditary nonpolyposis colorectal cancer, will be most effective when physicians understand the natural history and the molecular bases of these disorders.

6

\section{Leiomiossarcoma de Uretra: Relato de Caso em Paciente de 19 Anos}

\section{Gomes CHR, Guimarães PMS, Silva MR da, Mendes TG, Carvalho APV de, Silva JA da Fundação de Saúde Dilson de Quadros Godinho - Montes Claros (MG), Brasil}

Introdução: É uma neoplasia maligna, pouco frequente, de etiologia ainda desconhecida, provavelmente surgida na musculatura lisa da uretra. É quatro vezes mais frequente no sexo feminino. Dos tumores, apenas $5 \%$ são malignos. Em revisão de literatura (Guterres et.al, 1998), de 394 tumores de uretra excisados, apenas 22 eram malignos. $\mathrm{O}$ tratamento consiste em ressecção cirúrgica e a recorrência foi documentada em apenas três casos. Objetivo: Apresentar raro caso de paciente com leiomiossarcoma de uretra conduzido em nosso serviço. Métodos: Análise de prontuários e revisão de literatura. Relato do Caso: Os autores apresentam um caso de paciente do sexo feminino, de 19 anos, submetida à excisão cirúrgica de uma lesão sólida de cerca de $6 \mathrm{~cm}$, com alto índice mitótico e com imunoistoquímica mostrando leiomioma. A lesão recidivou sete meses após, sendo submetida à nova ressecção por via perineal com margens livres e reconstruçáo da uretra. $\mathrm{O}$ estudo histológico mostrou grande atividade mitótica, mas com imunoistoquímica novamente sugerindo lesão benigna. Apesar dos dados do exame, e segundo demais patologistas consultados, o comportamento e aspecto da lesấo sugerem fortemente tratar-se de leiomiossarcoma. Conclusáo: A paciente está em controle ambulatorial há cerca de oito meses, sem sinais de recidiva até o momento. 
Correlação dos Níveis Séricos Pré-Operatórios do CA 19-9 com o Acometimento Linfonodal Regional em Pacientes com Câncer Gástrico, Submetidos à Gastrectomia com Intenção Curativa, em Hospital de Referência Oncológica da Amazônia Oriental - Hospital Ophir Loyola (HOL)

Pacheco ACC, Lima IK, Souza AF, Ribeiro EKMA, Sena FG, Sousa RM Serviço de Cancerologia Cirúrgica, Hospital Ophir Loyola (HOL) - Belém (PA), Brasil

Objetivo: Demonstrar através de análise estatística a relevância do CA 19-9 alterado e o acometimento linfonodal dos pacientes submetidos à ressecçáo cirúrgica com intençẫo curativa. Método: Realizada análise prospectiva de 30 (trinta) doentes com diagnóstico histopatológico de adenocarcinoma gástrico, nos quais o estadiamento clínico não evidenciou doença disseminada ou irressecável. Com esses dados, procedeu-se à coleta de amostras de sangue para dosagem do CA 19-9, a seguir, os pacientes foram submetidos à laparotomia com estadiamento intraoperatório. Caso nâo houvesse sinais de irressecabilidade ou metástase, procedia-se à ressecção radical pretensamente curativa que consistia de gastrectomia subtotal ou total, omentectomia maior e menor e linfadenectomia a D2. Procedeu-se ao exame microscópico de todos os linfonodos ressecados, os quais foram previamente corados com hematoxilina-eosina. Resultado: Constatou-se CA 19-9 alterado no préoperatório em dez pacientes (33,33\%). Por outro lado, observou-se metástase, em um ou mais linfonodos, em 17 doentes $(56,66 \%)$. Com intuito de estudar estatisticamente a possível relação entre níveis do CA 19-9 com acometimento linfonodal, aplicou-se o método de Kolmogorov-Smirnov de acordo com as variáveis. Conclusão: Concluiu-se que não houve correlação significante entre níveis séricos pré-operatórios do CA 19-9 com acometimento linfonodal regional em pacientes com câncer gástrico submetidos à ressecçáo gástrica com intençáo curativa $(p>0,05)$.

9

\section{Comunicação do Diagnóstico de Neoplasia: Relato do Comportamento do Médico}

Gomes CHR, Guimarães PMS, Silva JA da, Ribeiro JA, Almeida JM de, Lima CC Fundação de Saúde Dilson de Quadros Godinho - Montes Claros (MG), Brasil

Introduçáo: $\mathrm{O}$ diagnóstico de câncer deixa de ser comunicado aos pacientes em grande parte das vezes, o que gera uma série de discussóes na área da ética médica. Objetivo: Analisar a conduta de médicos especialistas em oncologia e não especialistas quanto à comunicação do diagnóstico de câncer, bem como abordar as questóes éticas relacionadas a esse contexto. Métodos: Foram analisados, de maneira prospectiva, 396 pacientes, 291 do sexo feminino $(73,5 \%)$ e 105 do sexo masculino $(26,5 \%)$, encaminhados por 76 médicos ao ambulatório especializado de oncologia cirúrgica do serviço, já com diagnóstico firmado e comprovaçáo histológica, durante o período de setembro de 2002 a outubro de 2006. Resultados: O índice de omissão do diagnóstico foi de $28,5 \%$ (113 pacientes). Os médicos não especialistas deixaram de informar $87,9 \%$ dos seus pacientes, enquanto que os especialistas omitiram o diagnóstico em $6,4 \%$ dos casos. Os familiares dos doentes não informados foram comunicados somente em 31 casos $(27,4 \%)$. Em 16 vezes (14,2\%), foi solicitado em pré-consulta no ambulatório que o paciente não tomasse conhecimento da neoplasia. Conclusáo: A comunicaçáo do diagnóstico de câncer é dever do médico, mas os profissionais apresentam dificuldades em dialogar abertamente com os doentes. Os resultados demonstram a necessidade de melhorar o treinamento de habilidade em comunicação e ética durante a formação profissional a fim de melhorar a relaçáo médico-paciente e diminuir a angústia de pacientes e seus familiares.
Neoadjuvância em Câncer de Reto Baixo

Gomes CHR, Silva JA da, Carneiro JA, Moreira GR, Silveira JCM, Lima CC Fundação de Saúde Dilson de Quadros Godinho - Montes Claros (MG), Brasil

Introduçáo: $\mathrm{O}$ câncer de reto apresenta várias opçóes de conduta terapêutica. Apesar de a cirurgia ser o método eletivo, a radioterapia préoperatória vem demonstrando ser capaz de erradicar microscopicamente a neoplasia, possibilitando a preservação esfincteriana e de órgãos adjacentes, aumentando o potencial de cura e o controle local. Objetivos: Avaliar a influência da terapia neoadjuvante na reduçáo da extensão tumoral, através de dados histopatológicos e das variáveis preservação esfincteriana e tipo de cirurgia realizada. Método: Análise retrospectiva dos prontuários de pacientes portadores de adenocarcinoma de reto, localizados a até $6 \mathrm{~cm}$ da orla anal, tratados no período de junho de 2003 a junho de 2007. Resultados: Foram analisados 15 pacientes, sendo dez $(66,6 \%)$ do sexo feminino e cinco $(33,3 \%)$ do sexo masculino, com média de idade de 53 anos. Observou-se, através da retossigmoidoscopia, realizada antes da neoadjuvância e pré-operatória, regressão tumoral de $1 \mathrm{~cm}$ em três casos, $2 \mathrm{~cm}$ em dois, $3 \mathrm{~cm}$ em um e remissão macroscópica total em cinco, sendo que quatro pacientes nâo apresentaram alteraçốes. Após a radioterapia, seis pacientes foram submetidos à retossigmoidectomia, seis à amputação abdominoperineal, dois à exenteração posterior e um à exenteração pélvica total. $\mathrm{O}$ anatomopatológico revelou ausência de neoplasia residual microscópica em três casos. Conclusáo: A terapia neoadjuvante demonstrou, nesta série, ser capaz de reduzir o tamanho tumoral e até promover remissão patológica completa, no entanto, náo permitiu diminuir a ressecção de órgãos adjacentes ou oferecer segurança em tratamento, exclusivamente, não cirúrgico.

\section{Forequarter Amputation Under Combined Regional and Local Anesthesia}

Batista TP, Morais JA, Naspolini-Filho H, Ehrhardt RA, Lucena MA, Reis TJCC Centro de Oncologia, Hospital Universitário Oswaldo Cruz, University of Pernambuco, Recife, Pernambuco State, Brazil

Background: Forequarter amputation (FA) is a surgical treatment option for upper limb and shoulder girdle tumors to which general anesthesia is commonly used. However, the authors report one case of FA performed to treat a soft-tissue sarcoma fashioned under concurrent brachial plexus block and local anesthesia. Objective: Report the author's experience with use of concurrent brachial plexus block and local anesthesia to Berger's procedure. Method: Case report of a FA fashioned under brachial plexus block and local anesthesia. Results: A 64-years-old female patient with recurrent axillary malignant fibrous histiocytoma (stage III - T2bN0M0G4, according to TNM, 2002) and cardiovascular comorbidities underwent a FA under brachial plexus block and local anesthesia in order to minimize the risk of cardiovascular complications. The brachial plexus block was performed by anterior interscalenic approach after venous sedation. Additionally local anesthesia with 40 $\mathrm{ml}$ of a $1 \%$ lindocaína and $0.125 \%$ bupivacaine racemic solution was used in the posterior skin flap. There were no operative or postoperative complications and the patient was discharged from the hospital during the fifth day. She was referred to adjuvant radiotherapy and remains clinically free of recurrence upon 27 months follow-up at the ambulatory care. Conclusion: FA may be performed using a concurrent regional and local anesthesia in selected patients. 
Forequarter Amputation for Lymphatic Metastasis from Cutaneous Squamous Cell Carcinoma

Batista TP, Morais JA, Silva PA, Lucena MA, Ehrhardt RA, Reis TJCC Centro de Oncologia, Hospital Universitário Oswaldo Cruz, University of Pernambuco, Recife, Pernambuco State, Brazil

Background: Forequarter amputation (FA) represents a radical treatment option for scapular waist tumors that exceptionally may be used as surgical salvage and palliation for regional recurrent squamous cell carcinoma (SCC). Objective: Report a single-center experience with the Berger`s procedure to treat lymphatic metastasis from cutaneous SCC. Method: Case series of four FA performed by anterior approach to treatment of lymphatic metastasis from cutaneous SCC. Results: Four cases of FA performed for salvage treatment and palliation to patients with regional recurrent cutaneous SCC were retrospectively analyzed. All patients had stage III disease according to TNM classification and had been submitted to previous treatments in order to preserve the limb. In two cases, surgery had palliative intent and adjuvant radiotherapy was used. There was no record of trans-operative complications or mortality related to the procedure. Locoregional recurrence occurred in all patients after FA and only one of them could be treated with a second salvage cervical lymphadenectomy (levels II to V) and adjuvant radiotherapy. This one is still alive upon 7 years follow-up. The overall survival ranged from one to 83 months with mean of 28 months. Conclusion: FA may be a safe alternative of surgical salvage and palliation for regional recurrent cutaneous SCC.

\section{Aceleração da Recuperação Pós-Operatória em Pacientes Oncológicos com o Protocolo ACERTO}

Leal FS, Xavier JL, Aguilar-Nascimento JE, Diniz BN, Anabuki NT Universidade Federal de Mato Grosso - Hospital Universitário Júlio Müller, Cuiabá (MT0, Brasil

Introduçáo: Quando da indicaçấo de um tratamento cirúrgico, o paciente oncológico pode se encontrar frequentemente debilitado, o que tende a gerar complicaçôes no período pós-operatório. Sabe-se hoje que a adoção de protocolos multimodais pode ser uma estratégia bastante eficaz na redução de complicaçóes pós-operatórias e no tempo de internaçăo de maneira geral. Objetivos: Investigar a influência da adoçáo de um protocolo multimodal de condutas perioperatórias na evoluçáo de pacientes submetidos a cirurgias para ressecçáo de tumores. Material e Métodos: Foi realizado estudo prospectivo em 100 pacientes submetidos a cirurgias eletivas para ressecção de tumores. Quarenta e quatro pacientes no período pré-ACERTO (de janeiro de 2004 a julho de 2005) e 56 pacientes no pós-ACERTO (julho de 2005 a novembro de 2007). Comparouse incidência de complicaçóes, tempo de hospitalização e mortalidade entre os grupos. O protocolo ACERTO inclui: abreviação do jejum pré-operatório, realimentação precoce no pós-operatório, terapia nutricional perioperatória, antibiótico profilaxia, aboliçáo do preparo de cólon e reduçáo do volume de fluidos intravenosos no perioperatório. As operaçōes mais frequentes foram: gastrectomias (32\%), colectomias (25\%) e duodenopancreatectomias (11\%). Resultados: A mortalidade foi de $9 \%$ sem diferença estatística entre os grupos. O tempo de internaçáo pós-operatória foi maior no grupo pré-ACERTO, que também apresentou o dobro de complicaçóes infecciosas (26,2 vs. 7,1\% $\mathrm{p}=0,01$ ) quando comparado ao grupo pós-ACERTO. Conclusáo: A adoçáo do protocolo ACERTO melhorou os resultados pós-operatórios de pacientes submetidos à cirurgia para o tratamento de neoplasias, diminuindo a incidência de complicaçôes infecciosas e o tempo de internação após a operação.
Produtos Utilizados no Tratamento de Lesōes Neoplásicas Cutâneas

Pinto KCM da S, Silva RMP, Pereira AL, Ribeiro DB Hospital Santa Rosa, Hospital Araúio Jorge, Universidade Federal de Goiás, Hospital Regional Público do Araguaia Goiânia (GO), Brasil

Introduçáo: Lesões neoplásicas cutâneas afetam a integridade tissular e interferem na vida do paciente de forma global. Conhecer os principais produtos para tratar essas lesóes pode contribuir no estabelecimento do plano de cuidados efetivo ao paciente. Objetivo: Identificar evidências científicas sobre produtos usados como cobertura no tratamento de lesóes neoplásicas cutâneas. Metodologia: Revisão da Literatura, nas bases Lilacs, BDENF e Medline. Descritores usados: neoplasias malignas e bandagens, curativos oclusivos e neoplasias cutâneas, curativos biológicos e neoplasias cutâneas, ferimentos e lesōes e bandagens. Critérios de inclusão: Estudo primário abordando o uso coberturas no tratamento de lesão cutânea neoplásica em seres humanos, formato de artigo científico em português, inglês ou espanhol, de 2000 a 2007. Os dados foram analisados e extraídos de acordo com as categorias que emergiram. Resultados: Incluídos cinco estudos. As exclusōes podem ser explicadas pela dificuldade em delimitar a busca quanto ao idioma e ano nas bases pesquisadas, especificidade do tema, diversidade de estudos envolvendo outros tipos de feridas, tipos de publicaçốes que não estudo primário, repetiçôes de estudos. Os estudos abordaram: curativo de carváo ativado no controle do odor em feridas cutâneas malignas, metronidazol no controle do odor em feridas cutâneas malignas, e bandagem líquida de octyl-2-cyanoacrylate no tratamento de incisão cirúrgica após excisão de neoplasia cutânea. Conclusóes: A restauração tecidual não depende exclusivamente do curativo, mas também do câncer primário e fatores intervenientes; todavia, é imprescindível que o profissional compreenda que a escolha adequada do curativo pode estar diretamente relacionada com a melhora da qualidade de vida desses pacientes.

14

\section{A Sexualidade da Mulher Mastectomizada}

Silva RMP, Pereira AL, Gomes AN, Silva RM, Porto RA, Barreto I dos S Hospital Araújo Jorge, Universidade Salgado de Oliveira, Universidade Federal de

Introduçáo: As mamas simbolizam feminilidade, maternidade, sexualidade e erotismo; mas o câncer tem interferido e gerado sofrimento. Compreender como a mastectomia afeta a sexualidade da mulher pode contribuir para ampliar a visão acerca desse fenômeno, e melhorias nos planos de cuidados. Objetivo: Identificar o impacto da mastectomia na vida sexual da mulher. Metodologia: Descritivo exploratório, realizado em um Hospital Oncológico, em Goiânia, Goiás, com mulheres mastectomizadas. O projeto de pesquisa foi aprovado pelo CEP do Hospital Araújo Jorge. Coleta de dados realizada em abril de 2009, por entrevistas gravadas, direcionadas por roteiro e, posteriormente, transcritas na íntegra. Análise de dados por análise de conteúdo. Resultados: Participaram 12 mulheres, entre 35 e 69 anos; quatro casadas, três solteiras, duas viúvas, duas solteiras e uma desquitada. Dessas, seis relataram ter sofrido ansiedade e seis desenvolvido depressão. No desempenho sexual, quatro disseram não ter sofrido interferência ("não mudou nada minha vida amorosa"), três referiram piora no desempenho ("acho a vida sexual muito dificil... meu corpo deformado"), e cinco afirmaram melhora ("Melhorou muito, ficou mais carinhoso, cuidadoso"). $\mathrm{O}$ abandono foi relatado por duas mulheres ("me deixou depois do tratamento"). Agressáo pelo tratamento ("quimioterapias deixam a gente sem vontade") e o aspecto visual ("incomoda o visual') foram apontados como intervenientes. Conclusóes: $\mathrm{O}$ impacto da mastectomia na vida sexual esteve ligado ao emocional, processo de adaptação e enfrentamento, e ao apoio recebido pelo parceiro. Os planos de cuidados propostos devem atender a necessidades globais da mulher e seu parceiro. 
Sarcoma de Esôfago: Relato de Caso

\section{Cintra CA, Moreira RCL, Cesar BP, Paulinelli L, Salles PG de 0, Lima P} Instituto Mário Penna - Belo Horizonte (MG), Brasil

O carcinoma de células fusiformes do esôfago é uma neoplasia maligna rara $-0,1-2 \%$ de todas as neoplasias do esôfago -, caracteriza-se por ser uma mistura de células epiteliais (componente carcinomatoso) e fusiformes (componente epitelial), formando grandes massas polipoides e lobuladas no terço médio e inferior do esôfago. Relato de caso: J.H.M., masculino, 53 anos, apresentava disfagia progressiva até pastosos, odinofagia, dor torácica e perda ponderal de 9,5 Kg (P50kg) com dois meses de evolução. Endoscopia digestiva alta (EDA): lesão vegetante ulcerada, friável, com estenose em esôfago proximal, a 25 $\mathrm{cm}$ da arcada dentária superior (ADS). Anatomopatológico (AP): neoplasia fusocelular de alto grau (sugestiva de leiomiossarcoma). Imunoistoquímica: neoplasia fusocelular comprometendo lâmina própria. Tomografia Computadorizada (TC) de tórax: pequeno derrame pleural bilateral, atelectasia na base pulmonar direita, tumor infiltrante, vegetante e estenosante no terço médio do esôfago, com dilatação a montante e ausência de linfadenomegalias. Estudo contrastado do esôfago, estômago e duodeno: lesão expansiva, ulcerada, no terço médio do esôfago, de cerca de $10 \mathrm{~cm}$ de extensão, causando semiobstrução do fluxo de contraste. Optamos por Radioterapia (Rxt) e Quimioterapia exclusivas - sete ciclos de Dacarbazina + Adriamicina, num período de seis meses e 25 sessóes de Rxt - dose total de 5.040cGy em dois meses. Controle 15 meses pós-tratamento: assintomático, sem disfagia e com recuperaçáo da perda ponderal prévia $(\mathrm{P} 71 \mathrm{~kg})$. TC de tórax: ausência de lesóes parenquimatosas, dilatação da luz esofágica e ausência de linfadenomegalias. EDA: área fibrosada no esôfago com $6 \mathrm{~cm}$ de extensão a partir de $26 \mathrm{~cm}$ da ADS.

Texto Truncado

17

\section{Avaliação do Efeito de Acetona Cianidrina na Inativação de Células do Tumor Ascítico de Ehrlich "In Vitro"}

Objetivo: A pesquisa teve a finalidade de avaliar a Acetona Cianidrina como fonte de cianeto, sobre células do Tumor Ascítico de Ehrlich (TAE), comparando com linfócitos humanos (LH). Métodos: Células do TAE e LH foram incubadas com diferentes concentraçôes de Acetona Cianidrina $\left(0,0,5,1,0,2,0,10,0,20,0\right.$ e $\left.30,0 \mu \mathrm{g} \cdot \mathrm{mL}^{-1}\right)$, depois de $1,2,3,4,18$ e 24 horas foi verificada a viabilidade celular através do método de azul de trypan. $\mathrm{O}$ resultado foi analisado pelo teste ANOVA e pós-teste de Bonferroni, com $\mathrm{p}<0,05$. Resultados: Os resultados demonstraram um efeito citotóxico dose dependente. Nas concentraçóes de 20 e $30 \mu \mathrm{g} \cdot \mathrm{mL}^{-1}$, ocorreu $100 \%$ de morte celular em apenas 1 e 2 horas. Nas doses mais baixas de 0,5, 1,0 e 2,0 $\mu \mathrm{g} . \mathrm{mL}^{1}$, o efeito citotóxico foi menos intenso, aumentando gradativamente com o tempo. Quando comparados os tempos de incubação dos LH com os tempos de incubação das células de TAE, foram observadas diferenças significativas em praticamente todos os tempos e concentraçôes de Acetona Cianidrina $(\mathrm{p}<0,001)$. Conclusóes: Nas concentraçóes baixas de $0,5,1,0$ e $2,0 \mu \mathrm{g} \cdot \mathrm{mL}^{1}$, foram observadas mais de $90 \%$ de morte celular após 24 horas de incubação, evidenciando a capacidade da célula tumoral de se intoxicar de maneira irreversível e acumulativa com a Acetona Cianidrina; nos LH nas mesmas doses e nos mesmos tempos de incubação atingiram um máximo de $30 \%$ de morte celular, o que sugere uma atividade de rodanase diferenciada entre as duas células.

\section{Prevalência da Mortalidade por Câncer em Crianças na Cidade de Porto Alegre (RS), Brasil}

\author{
Sampaio FH de, Zandoná B, Faria-Corrêa BM de, Gomes MWS, Thoen RH, Oliveira \\ TMC de, Onsten TGH \\ Universidade Luterana do Brasil (ULBRA) - Canoas (RS), Brasil
}

Introdução: $\mathrm{O}$ câncer infantil é infrequente. Estima-se que, anualmente, cerca de 300 novos casos de câncer em indivíduos entre 0 a 19 anos ocorram no RS. Essa doença representa a terceira causa de morte por doença na população entre 1 e 14 anos. Objetivo: Investigar os índices de mortalidade por câncer na cidade de Porto Alegre em crianças de 0 a 10 anos, identificando os tipos mais prevalentes nessa faixa etária. Materiais e Métodos: Estudo descritivo transversal realizado através da análise dos dados de mortalidade por tipo de câncer, segundo CID-10 disponível no DATASUS, entre 2000 e 2005, em crianças de 0 a 10 anos, na cidade de Porto Alegre. Resultados: Identificou-se 296 mortes ocorridas, sendo $79(26,7 \%)$ por leucemia; $75(25,3 \%)$ por câncer de meninges, de encéfalo ou de outras partes do SNC; $20(6,7 \%)$ por carcinoma in situ, benigno e de comportamento incerto; 17 (5,7\%) por linfoma nâo Hodgkin; dez $(3,4 \%)$ por câncer de fígado e vias biliares intra-hepáticas; um $(0,3 \%)$ por câncer de ovário; um $(0,3 \%)$ por câncer de bexiga; um $(0,3 \%)$ por câncer de pele e $92(31 \%)$ pelo restante de neoplasias malignas. Conclusáo: Em Porto Alegre, a maior mortalidade específica por câncer em crianças de 0 a 10 anos se dá por leucemia, seguida por câncer em meninges, encéfalo e outras partes do sistema nervoso central e por carcinoma in situ, benignos e de comportamento incerto. Assim, foi possível estabelecer o perfil de mortalidade infantil em crianças de 0 a 10 anos em Porto Alegre.

\section{Microsatellite Instability and Endometrial Cancer in Patients at the Brazilian Cancer Institute}

\section{Chaves CBP, Leite VP, Silva BP, Moreira FCB, Ramalho DMP, Rocha JCC Brazilian Cancer Institute, Rio de Janeiro (RJ), Brazil}

Defective DNA mismatch repair causes genomic instability in different regions, including those called microsatellite. The impact of microsatellite instability (MSI) on survival in sporadic endometrial carcinoma was our objective. MSI frequency was evaluated in endometrial adenocarcinoma patients who underwent surgical treatment at the Brazilian Cancer Institute from january, 2000 to december, 2003. Tumor and normal tissue DNA was extracted from paraffin blocks. Six different microsatellite regions were amplified by PCR technique and compared for identifying MSI by Agilent 2100 Bioanalyzer. 231 patients were studied and median age was 64 (25-90). MSI (high and low) was present in $75(32.5 \%)$ patients and stable tumors (MSS) in $150(64.9 \%)$. No amplification was observed in $6(2.6 \%)$ patients. Assessing the amplified patients (225), endometrioid subtype (Type I) was diagnosed in $82.7 \%$ (186) of cases and MSI was present in 34.4\% (64) of them; non endometrioid subtype (Type II) was detected in $14.2 \%$ (32) and MSI in 25\% (8) of them. Seven (3.1\%) were inconclusive. MSI was found in $42.9 \%$ (3) of them. According to FIGO staging criteria 137 (60.9\%) patients were stage I; 47 (20.9\%) stage II; 36 $(16.0 \%)$ stage III; 5 (2.2\%) stage IV. Kaplan-Meier Test demonstrated overall survival was statistically signicant $(\mathrm{p}=0.016)$ when three different microsatellite categories were assessed, as well as when microsatellite status impact was compared to histologic subtypes and FIGO staging criteria ( $\mathrm{p}=0.032$ and $\mathrm{p}=0.006$, respectively). We conclude microsatellite status is significant for overall survival outcome, suggesting its influence on prognosis is assertive. 
Câncer Medular de Tireoide (CMT) com Metástase Tardia para Fígado

Cruz RP, Faria-Corrêa BM de, Gomes MWS, Mottin C, Grecco C, Pires IS Centro de Cirurgia Endócrino Metabólica da PUCRS, Porto Alegre (RS), Brasil

Introduçáo: O CMT é raro, originário das células parafoliculares tireoidianas. Objetivos: Descrever relato de caso de paciente da PUCRS, com diagnóstico de CMT em 2003, apresentando metástases hepáticas cinco anos após diagnóstico. Material e Métodos: Descrição de caso clínico a partir de dados clínicos, laboratoriais e cirúrgicos. Resultados: Mulher, 23 anos, história familiar de neoplasia tireoidiana com aumento de volume cervical anterior associado à dor. Queixas: disfagia, perda de $8 \mathrm{~kg}$, suor e queda capilar excessiva, pele seca, e constipaçăo. Exame físico: aumento tireoidiano com nodularidade bilateral. Laboratoriais: T3 elevado. Cintilografia com contraste iodado: bócio multinodular. PAAF: sugeria bócio coloidal multinodular. Realizada tireodectomia total. Anatomopatológico: CMT, margens cirúrgicas, cápsula e sistema linfático livres. Imunoistoquímica: CMT. Nova cintilografia: sem captaçáo em regiáo cervical. Após cinco meses, apresentou massa cervical à direita com função tireoidiana. Calcitonina sérica e CEA normais. Com cinco anos de seguimento, TC de abdômen mostrou imagem compatível com metástase hepática, confirmada por Imunoistoquímica de material coletado por punção guiada por US. Procedeu-se à hepatectomia direita. Progrediu com elevação da calcitonina sérica e diarreia aquosa. Nova US evidenciou novas metástases hepáticas. Realizada nova hepatectomia com evoluçáo para óbito em um mês. Conclusáo: O CMT representa menos de $10 \%$ das malignidades tireoidianas. História familiar é positiva em $25 \%$ dos casos, sendo a maioria esporádica. Fatores prognósticos relevantes: idade ao diagnóstico, gênero masculino, extensão inicial da doença, tamanho do tumor, invasáo vascular, calcitonina sérica e dosagem de amiloide tumoral. Curável apenas por tireodectomia e se tumor limitado à glândula. A maioria dos óbitos relaciona-se às metástases.

21

\section{Carcinoma Recorrente de Paratireoide Manejado Cirurgicamente com uso de Gamma Probe}

Cruz RP, Faria-Corrêa BM, Gomes MWS, Mottin C, Padoin A V, Ramos RJ Centro de Cirurgia Endócrino Metabólica da PUCRS - Porto Alegre (RS), Brasil

Introduçáo: $\mathrm{O}$ Carcinoma de Paratireide $(\mathrm{CP})$ é uma neoplasia rara (-0,005\% dos cânceres). Objetivos: Descrever relato de caso de paciente com CP recorrente, manejado cirurgicamente e Gamma Probe (GP). Métodos: Descrição de caso clínico a partir de dados clínicos, laboratoriais e cirúrgicos. Resultados: Homem, 30 anos, queixas: rouquidão, fraqueza dos membros e dor progressiva nos inferiores (MI) em quatro anos. Hipotrofia do quadríceps. Exames séricos: cálcio ionizado $8 \mathrm{mg} / \mathrm{dL}$, total $14,2 \mathrm{mg} / \mathrm{dL}$ e cálcio urinário 714 ; fósforo $1,7 \mathrm{mg} / \mathrm{dL}$; PTH $1.251 \mathrm{pg} /$ $\mathrm{mL}$; fosfatase alcalina 1.434U/L. Radiologia: osteopenia, osteólise, reabsorção óssea e radiotransparência em mãos, clavícula E, quadril, e MI. Cintilografia óssea: hipercaptação difusa e hiperatividade em focos ósseos nos membros. Cintilografia com Sestamibi (CS): hipercaptação no lobo inferior E tireoidiano. Realizada paratireoidectomia inferior E. Congelação: adenoma de paratireoide. Imunoistoquímica: $\mathrm{CP}$ bem diferenciado. Após a cirurgia, apresentou melhora parcial da força e diminuiçấo da dor. PTH baixou, mas não normalizou. PTH aumentou nos dois anos seguintes, com reincidência de sintomas. US cervical: duas imagens hipoecogênicas ovalares, bem delimitadas, em porção inferior tireoidiana. TC cervical, torácica e abdominal normais. Realizadas três CSs após a cirurgia; apenas a última mostrou área hipercaptante. Realizada lobectomia $\mathrm{E}$, utilizando GP, demonstrando pequena hipercaptaçâo. Após a cirurgia, o PTH baixou e o paciente apresentou melhora da dor óssea. Patologia: hiperplasia de paratireoide superior E; disseminação neoplásica invadindo musculatura pré-tireoidea; lobo tireoideo e linfonodos livres. Após um mês, PTH ainda elevado. Conclusáo: $\mathrm{OCP}$ é uma neoplasia rara, que frequentemente não é reconhecida pelo cirurgiáo durante a cirurgia, piorando o prognóstico. $\mathrm{O}$ uso do GP pode auxiliar na identificaçāo do tumor durante a reintervençāo.
Adenocarcinoma Gástrico em Paciente HIV Positivo: Relato de Caso

Ribeiro RG, Moreira RCL, Saraiva CM, Cintra CA, Salles PGO, Martins MPR Hospital Luxemburgo - Mário Penna - Belo Horizonte (MG), Brasil

Introduçáo: Portadores de HIV possuem risco aumentado para o desenvolvimento de infecçốes oportunistas e certos tipos de câncer. As neoplasias mais frequentes são: Sarcoma de Kaposi e o Linfoma não Hodgkin. Relato de caso: C.A.F 45 anos, masculino, HIV positivo em uso regular de drogas antirretrovirais (ARVs), encaminhado ao serviço com relato de emagrecimento e epigastralgia. EDA: lesão pré-pilórica. AP: adenocarcinoma gástrico tipo intestinal de Lauren. TC de abdômen: ausência de metástases esplênicas e hepáticas; linfadenomegalia mesentérica e aortocaval. Discutido com infectologia e optado por tratamento operatório. Submetido à gastrectomia à Billroth I, linfadenectomia à D2 e biópsia de linfonodos mesentéricos. AP: adenocarcinoma gástrico tipo intestinal, intramucoso, linfonodos livres. Realizado pesquisa de microorganismos e cultura de linfonodos (negativas). Imunoistoquímica confirmou o diagnóstico. Não indicada terapia adjuvante. Permanece em controle há 44 meses, sem sinais de recidiva de doença. Discussáa: A incidência de infecçóes por HIV e câncer continua aumentando em nosso meio. $\mathrm{O}$ uso dos ARVs modifica a qualidade e a expectativa de vida dos pacientes soropositivos, permitindo a manifestaçáo dos cânceres com longo período de latência. Pacientes selecionados para tratamento cirúrgico deverão apresentar ótimo performance status e níveis adequados de carga viral e CD4. A Imunoistoquímica auxilia na exclusão de linfoma gástrico. $\mathrm{O}$ estudo dos linfonodos descarta doenças oportunistas associadas. Os princípios básicos da cirurgia oncológica devem ser preservados e equipamentos de proteçấo e biossegurança devem ser utilizados. Conclusáo: Cirurgias de grande porte em pacientes soropositivos podem ser realizadas desde que respeitados os critérios clínicos e cirúrgicos para indicaçáo.

\section{Gastrectomia Laparoscópica (Técnica de Sleeve) como Tratamento para GIST Gástrico}

Cruz RP, Faria-Corrêa BM, Gomes MWS, Mottin C, Padoin AV, Ramos RJ Centro de Cirurgia Endócrino Metabólica da PUCRS - Porto Alegre (RS), Brasil

Introdução: O Tumor estromal gastrointestinal (GIST) é um sarcoma raro $(0,2 \%$ dos tumores $\mathrm{GI}), 70 \%$ gástricos. Seu tratamento de escolha é laparotomia, mas a ressecçáo laparoscópica vem se tornando eficaz. Objetivos: Descrever relato de caso de paciente da PUCRS, com GIST gástrico, operado por gastrectomia parcial laparoscópica, sem complicaçấo. Material e Métodos: Descriçáo de caso clínico a partir de dados clínicos, laboratoriais e cirúrgicos. Resultados: Homem, 56 anos, com dor epigástrica recorrente há dez anos. US abdominal: esteatose hepática, vesícula biliar e ducto biliar comum normais, linfonodos pré-aórticos aumentados. Colecistograma oral: discinesia biliar. TC: esteatose hepática. RM: tumor de margens regulares e contínuas com fundo gástrico, compatível com GIST subseroso. US endoscópica: lesão homogênea com calcificaçōes centrais, medindo $31 \mathrm{~mm}$ x $31 \mathrm{~mm}$ de diâmetro, de musculatura própria. Realizada gastrectomia laparoscópica parcial por Sleeve, colecistectomia e biópsia. Patologia: neoplasia mesenquimal, compatível com GIST, medindo 4 x 2,6 cm, margem negativa; colecistite crônica; biópsia hepática: densa esteatose hepática de microvasculatura e grande expansão fibrosa peri-portal. Imunoistoquímica positiva para CD 117, c-Kit(1DC3), Ki67(HB11) e anticorpos EGFR - GIST grau intermediário. Recebeu alta em oito dias. Três meses depois, US abdominal revelou nódulos hepáticos sugestivos de metástases. Iniciou-se Mesilato de Imatinibe. Cinco meses após cirurgia, apresentava saciedade precoce. Conclusáo: $\mathrm{O}$ tratamento de escolha para GIST primário não metastático é ressecção local com margens livres. A ressecçáo laparoscópica tornou-se um tratamento eficaz permitindo recuperaçăo mais rápida e menor dor pós-operatória. Contudo a maioria dos estudos apresenta séries com pouco tempo de acompanhamento, sendo necessários novos estudos para determinar a segurança do tratamento laparoscópico. 


\section{Evaluation of V600E BRAF Gene Mutation in Endometrial Cancer}

Chaves CBP, Silva BP, Leite VP, Moreira FCB, Ramalho DMP, Rocha JCC Brazilian Cancer Institute - Rio de Janeiro (RJ), Brazil

V600E mutation type (the amino acid valine is replaced by the amino acid glutamic acid at position 600 of the BRAF protein) in $B R A F$ gene has been described in colorectal, ovarian and thyroid tumors and melanoma. $B R A F$ is located on the long arm of chromosome 7 in region 34 , has 18 exons and the most common place of mutation is exon 15 . It is a proto-oncogene once altered can be involved on transduction of signals for proliferative stimuli, angiogenic, invasion and metastasis, and apoptosis evasion. Literature has already mentioned only one study of this mutation in endometrial cancer: two patients on 40 cases. The objective was the assessment of possible mutation of BRAF V600E (specifically in exon 15) in sporadic endometrial cancer in patients enrolled at Brazilian Cancer Institute. Tumor tissue DNA was extracted from paraffin blocks of patients who underwent surgery from January, 2000 to December, 2004. PCR technique for amplification of exon 15 was applied and GE kit (GFX PCR DNA and Gel Band Purification kit) was used for purifying these samples. BRAF gene sequences were read by MegaBACE sequencing equipment. So far no mutation in $B R A F \mathrm{~V} 600 \mathrm{E}$ was found after three-year-sample-assessment (175 patients). Tissues preserved in paraffin blocks seem to be less sensitive for sequencing. We decided to change strategy and apply allele-specific PCR technique using intestinal and thyroid cell lines as positive control, since this method seems to be more sensitive to $B R A F$ mutation presence in paraffin preserved tissues. Texto Truncado

\section{Melanoma Familial - Família com 12 irmãos, Sendo seis Acometidos por Melanoma com Dez Primários}

Wainstein AJA, Oliveira BRR, Castro E, Parreiras FC, Bittencourt F V, Lage APD ONCCAD - BIOCANCER - Hospital Alberto Cavalcanti - Hospital das Clínicas - UFMG

Introduçáo: Aproximadamente 5\% a 11\% dos pacientes com melanoma possuem outros familiares com a mesma neoplasia. O seguimento dos pacientes diagnosticados é de grande importância na identificação de famílias de risco. Os genes CDK4 e CDKN2A são os mais relevantes na contribuiçáo genética do melanoma. Acompanhamento de famílias de alto risco para melanoma mostram pacientes mais jovens e com diagnóstico mais precoce, o que leva a um melhor prognóstico. Identificação de uma família com alta prevalência de melanoma que permita estudos relevantes do componente genético dessa neoplasia. Relato de Caso: Análise de uma família com 12 filhos, na qual pai e mấe não apresentavam melanoma e seis filhos foram diagnosticados com melanoma. Os pacientes apresentam pele tipo 2 e náo apresentam síndrome do nevo displásico. Os casos acometidos são: sexo masculino, melanoma aos 28 anos, óbito aos 37 anos; sexo masculino, 30 anos, apresentou dois melanomas localizados no dorso e um frontal esquerdo; sexo masculino, 34 anos, apresentou um melanoma cervical; sexo feminino, 37 anos, apresentou dois melanomas pré-esternais e um malar esquerdo; sexo feminino, 44 anos, apresentou um melanoma na regiáo temporal esquerda; sexo feminino, 33 anos, apresentou dois melanomas cervicais e um malar. Conclusáo: Todos os familiares acometidos e não acometidos tiveram suas amostras biológicas coletadas e estão sendo estudadas para correlação genética. Na primeira análise não foram identificadas as mutaçóes mais prevalentes nos genes CDK4 e CDKN2A. O DNA dos pacientes está sendo sequenciado em busca de uma correlaçáo genética e clínica.

\section{Tumor Estromal Gastrointestinal (GIST) de Intestino Delgado: Relato de Caso} Aguiar IT, Ibañez Nunes S, Louzada CF, Oliveira TC, Lourenço MBS, Marques e Oliveira EC
Fundaçõo Hospitalar do Estado de Minas Gerais - Hospital Regional de Barbacena -
Barbacena (MG), Brasil

Introdução: O GIST representa $80 \%$ dos tumores mesenquimais gastrointestinais e 5-6\% dos sarcomas, originando-se nas células intersticiais de Cajal. Sessenta por cento dessas neoplasias ocorrem no estômago, 20$30 \%$ no intestino delgado e $10 \%$ acometem esôfago, colón e reto. A maior incidência ocorre nas $5^{\mathrm{a}}$ e $6^{\mathrm{a}}$ décadas de vida. São assintomáticos, porém, podem apresentar sangramento, dor abdominal, massa palpável ou obstruçăo intestinal, sobretudo em lesōes volumosas. A metastização não tem um padrão definido, relacionando-se a prognóstico reservado. Objetivos: Descrever caso de GIST volumoso de intestino delgado. Material e Métodos: Informaçôes obtidas por anamnese, exames físico e complementares e seguimento. Relato do Caso: G.J.N., 65 anos, com quadro de dor abdominal e tumoração palpável em andar inferior do abdômen. Ao exame físico, massa palpável em pelve, móvel, de consistência elástica. US abdominal revelou lesão expansiva em abdômen medindo $16,5 \mathrm{~cm} \times 12 \mathrm{~cm} \times 11 \mathrm{~cm}$. TC abdominal revelou volumosa formação expansiva em pelve, sugerindo abscesso ou massa. Laparotomia evidenciou massa volumosa em intestino delgado de $25 \mathrm{~cm}$ x $30 \mathrm{~cm}$, comprometendo duas alças de jejuno. À macroscopia, ausência de metástase. Foi realizada exérese total da massa e ressecção das alças de jejuno comprometidas, com anastomose término-terminal. Pós-operatório sem intercorrências. Estudo anatomopatológico evidenciou GIST de intestino delgado. Recebeu alta hospitalar no $14^{\circ}$ dia de pós-operatório, encaminhado para oncologia. Conclusôes: Diagnósticos diferentes dos usuais devem ser sempre considerados e o cirurgiáo deve estar preparado para resolver situaçóes diversas no transoperatório. Embora o GIST já tenha comprometido parte do jejuno e apresentado grandes dimensōes ao procedimento cirúrgico, foi possível removê-lo totalmente, preservando, ao máximo, as estruturas adjacentes. 26

\section{Ressecção de Metástase Hepática de Adenocarcinoma de Pâncreas: Relato de Caso}

Almeida AML, Guerini BS, Crespo GS, Futuro JBD, Milezi WSG, Santos RCentro Universitário Serra dos Órgãos (UNIFESO) Vitória Apart Hospital

O adenocarcinoma de pâncreas é a segunda neoplasia maligna gastrointestinal mais comum. A ressecçáo cirúrgica oferece a única chance de cura. Mesmo nos pacientes com doença potencialmente ressecável, o prognóstico é reservado. A metástase hepática é uma das maiores causas de óbito após a ressecção do adenocarcinoma pancreático. O objetivo deste trabalho é relatar um caso de adenocarcinoma de pâncreas tratado inicialmente com duodenopancreatectomia parcial com linfadenectomia regional estendida, que foi submetido à ressecçấo de metástase hepática e terapia adjuvante um ano após a primeira cirurgia, e demonstrar que houve aumento na sobrevida e melhora na qualidade de vida do paciente. Foi realizada revisão de prontuário e bibliográfica. O prognóstico da maioria dos pacientes permanece não favorável, pois o estágio do carcinoma ao diagnóstico continua avançado. É muito comum o achado de recorrência local e a distância, que são tratadas com cirurgias paliativas, quimioterapia ou radioterapia, ao invés de usufruir operação mais radical. Essa conduta segue as diretrizes sugeridas que relatam como um dos critérios de irressecabilidade o envolvimento extra-hepático pela doença primária. Estudos mostram que a ressecção hepática é uma opção cirúrgica disponível segura para o tratamento de malignidades primárias e secundárias do fígado. 
Reconstrução com Prótese Vascular de Vasos Femorais após Ressecção Cirúrgica por Invasão Tumoral de Melanoma Metastático, em Hospital de Referência Oncológica da Amazônia Oriental Hospital Ophir Loyola

Lima IK, Souza AF, Ribeiro EKA, Sena FG, Sousa RM, Homma T K Serviço de Cancerologia Cirúrgica, Hospital Ophir Loyola (HOL) - Belém, (PA), Brasil

Objetivo: Apresentar um caso de melanoma metastático para região inguinal comprometendo os vasos femorais, que foi submetido à ressecção cirúrgica e reconstrução vascular do mesmo. Com isso, demonstrar os benefícios do procedimento relacionados à sobrevida e qualidade de vida do paciente. Relato: Masculino, 71 anos, há dois anos com diagnóstico de melanoma em coxa direita. Submetido à exérese e quimioterapia adjuvante, evoluindo com lesão metastática em região inguinal direita. Realizada exérese em bloco da lesão, incluindo os vasos femorais e linfadenectomia inguinoilíaca direita. Reconstruçáo arterial utilizando prótese de PTFE (polytetrafluoroethylene) e reconstrução da veia utilizando enxerto de veia safena magna, sem intercorrências. Evoluindo com infecção de sítio cirúrgico, porém sem comprometimento de enxerto, alta no $30^{\circ}$ dia de pós-operatório, realizou quimioterapia adjuvante, atualmente em seguimento ambulatorial sem sinais de recidiva tumoral, com funçáo do membro mantida e boa qualidade de vida. Discussáo: $\mathrm{O}$ tratamento das neoplasias malignas nos casos em que o feixe vascular é afetado indica que a revascularização arterial após ressecção tem um importante papel terapêutico ao restabelecer a condição do eixo arterial e evitar assim a isquemia. Atualmente, as técnicas de reconstrução de grandes estruturas vasculares apresentam um alto grau de confiabilidade e durabilidade, permitindo a preservação física com boa parte da função e obviamente melhor qualidade de vida. Conclusáo: Concluímos que a ressecção de grandes vasos sanguíneos e sua reconstrução, em pacientes selecionados, pode trazer aumento da sobrevida com qualidade de vida para o doente, sendo uma técnica factível e segura de execução. 29

\section{Distribuição da Modalidade de Tratamento Realizado em Pacientes Portadores de Carcinoma de Canal Anal, Tratados em Hospital de Referência Oncológica da Amazônia Oriental - Hospital Ophir Loyola (HOL)}

Soares PC, Lima IK, Souza AF, Ribeiro EKMA, Sena FG, Sousa RM Serviço de Cancerologia Cirúrgica, Hospital Ophir Loyola (HOL) - Belém (PA), Brasil

Introduçáo: $\mathrm{O}$ câncer de canal anal é uma patologia rara. Fatores de risco como: infecção crônica por Papiloma Vírus Humano (HPV), imunossupressão, tabagismo e intercurso anal são bem definidos. A sobrevida em cinco anos encontra-se, em torno, de $73 \%$ para mulheres e de $60 \%$ para homens. A sobrevida, em cinco anos, com radioquimioterapia combinada, varia entre $56 \%$ a $83 \%$, com resposta completa até de $90 \%$. Objetivo: Analisar a distribuição em relaçáo ao tratamento de pacientes portadores de neoplasia maligna de canal anal. Método: Foram estudados 45 indivíduos portadores de carcinoma do canal anal, atendidos no Hospital Ophir Loyola, no período de 1998 a 2000, sendo realizada análise estatística com o teste do Qui-quadrado. Resultado: Dez pacientes foram submetidos a tratamento cirúrgico $(22,2 \%)$, um paciente tratado com quimioterapia exclusiva $(2,2 \%)$, três com radioterapia $(6,7 \%)$, enquanto 31 pacientes foram tratados com radioquimioterapia (68,9\%). P-valor $<0,0001$ (Qui-Quadrado). Conclusáo: $\mathrm{O}$ tratamento radioquimioterápico correspondeu a grande maioria dos pacientes, representando análise estatística relevante, quando comparada a outros métodos terapêuticos empregados.
Análise Estatística da Resposta ao Tratamento do Carcinoma de Canal Anal de Pacientes Atendidos em Hospital de Referência Oncológica da Amazônia Oriental - Hospital Ophir Loyola (HOL)

Soares PC, Lima IK, Souza AF, Ribeiro EKMA, Sena FG, Sousa RM Serviço de Cancerologia Cirúrgica, Hospital Ophir Loyola (HOL) - Belém (PA), Brasil

Objetivo: Demonstrar em análise estatística a resposta do tratamento do câncer de canal anal, de pacientes portadores de neoplasia maligna de canal anal, tratados no Hospital Ophir Loyola (HOL), Belém (PA). Método: A casuística foi constituída por 45 indivíduos portadores de carcinoma do canal anal, atendidos na Seção de Cirurgia Abdominopélvica do Departamento de Oncologia do HOL, no período de 1998 a 2000. O estadiamento desses tumores foi realizado através do exame clínico, complementado com dados endoscópicos e radiológicos, através do sistema TNM. Em seguida, foram encaminhados ao tratamento do carcinoma de células escamosas do canal anal, constando de radioquimioterapia ou radioterapia exclusiva, associadas ou não à ressecção cirúrgica local ou ampliada e colostomia quando indicada, sendo realizada análise estatística com o teste do Qui-quadrado. Resultados: As respostas ao tratamento foram: completo em 26 pacientes (57,8\%); parcial em 17 (37,8\%); e sem resposta em dois casos (4,4\%); p-valor $<0,0001$ (Qui-Quadrado). Conclusão: Do tratamento proposto, $57,8 \%$ dos pacientes obtiveram resposta completa, o que representa a maioria, sendo a análise estatística relevante.

Distribuição dos Marcadores Tumorais CA 19-9, CEA e CA 72-4 de acordo com o Acometimento Linfonodal, em Pacientes com Adenocarcinoma Gástrico Submetidos à Ressecção Gástrica com Intenção Curativa, em Hospital de Referência Oncológica da Amazônia Oriental - Hospital Ophir Loyola

Pacheco ACC, Lima IK, Grande JC, Ribeiro EKMA, Sena FG, Sousa RM Serviço de Cancerologia Cirúrgica, Hospital Ophir Loyola (HOL) - Belém (PA), Brasil

Objetivo: Demonstrar através de análise estatística a relevância dos marcadores tumorais alterados conjuntamente e o acometimento linfonodal do estudo em questão. Método: Foi realizado estudo prospectivo em 30 pacientes de ambos os sexos, internados no Hospital Ophir Loyola (HOL), Belém (PA), com diagnóstico de câncer gástrico e submetidos à dosagem do nível sérico de CA 19-9, CEA e CA 7z2-4, então submetidos à gastrectomia radical D2. Com intuito de estudar estatisticamente uma possível relação entre níveis desses marcadores tumorais com acometimento linfonodal, aplicouse o método Kolmogorov-Smirnov de acordo com as variáveis. Resultado: Analisando-se o número total de 14 pacientes com um ou mais marcadores alterados, 12 (85,71\%) encontravam-se com o comprometimento linfonodal ( $p>0,05)$. Conclusão: Concluiu-se que não houve correlação significante entre níveis séricos pré-operatórios dos marcadores estudados com acometimento linfonodal regional em pacientes com câncer gástrico submetidos à ressecção gástrica com intenção curativa. 
Correlação dos Níveis Séricos Pré-Operatórios do CA 72-4 e CEA com o Acometimento Linfonodal Regional em Pacientes com Câncer Gástrico Submetidos à Gastrectomia com Intenção Curativa, em Hospital de Referência Oncológica da Amazônia Oriental - Hospital Ophir Loyola (HOL)

Pacheco ACC, Lima IK, Souza AF, Ribeiro EKMA, Sena FG, Sousa RM Serviço de Cancerologia Cirúrgica, Hospital Ophir Loyola (HOL) - Belém (PA), Brasil

Objetivo: Estudar as possíveis correlaçóes entre os níveis séricos de CEA e CA 72-4 com o acometimento linfonodal de doentes portadores de adenocarcinoma gástrico. Método: Análise prospectiva de 30 doentes com diagnóstico histopatológico de adenocarcinoma gástrico, nos quais o estadiamento clínico não evidenciou doença disseminada ou irressecável. Com esses dados, procedeuse à coleta de amostras de sangue para dosagem dos marcadores tumorais acima citados e, a seguir, os pacientes foram submetidos à laparotomia, estadiamento intraoperatório. Caso não houvesse sinais de irressecabilidade ou metástase, procedia-seà ressecçáo radical pretensamente curativa que consistia de gastrectomia subtotal ou total, omentectomia maior e menor e linfadenectomia à D2. Procedeu-se ao exame microscópico de todos os linfonodos ressecados, os quais foram previamente corados com hematoxilina-eosina. Com intuito de estudar estatisticamente uma possível relaçáo entre níveis desses marcadores tumorais com acometimento linfonodal, aplicou-se o teste Kolmogorov-Smirnov de acordo com as variáveis. Resultado: Constatou-se CEA alterado no pré-operatório em cinco pacientes dos 17 doentes com um ou mais linfonodos comprometidos $(56,66 \%)$. Correlacionando-se os níveis pré-operatórios deCA72-4 e a positividade linfonodal à histopatologia dos pacientes acometidos, apenas seis apresentaram CA 72-4 com níveis elevados, enquanto que, dos 13 pacientes com linfonodos negativos, apenas um apresentou níveis sanguíneos elevados desse marcador, estatisticamente avaliado com teste Kolmogorov-Smirnov ( $p>0,05)$. Conclusáo: Náo houve correlação significante entre níveis séricos pré-operatórios do CEAe CA 72-4 com acometimento linfonodal regional em pacientes com câncer gástrico submetidos à ressecção gástrica com intençáo curativa. 33

Estudo Epidemiológico Correlacionando à Sobrevida em Meses, de Pacientes Portadores de Carcinoma de Canal Anal com o Estadiamento Clínico em Hospital de Referência Oncológica na Amazônia Oriental - Hospital Ophir Loyola (HOL)

Soares PC, Lima IK, Souza AF, Ribeiro EKMA, Sena FG, Sousa RM Serviço de Cancerologia Cirúrgica, Hospital Ophir Loyola (HOL) - Belém (PA), Brasil

Objetivo: Apresentar estudo correlacionando a sobrevida global com o estadiamento clínico em pacientes portadores de câncer de canal anal, tratados no Hospital Ophir Loyola, Belém (PA). Método: Foram estudados 45 pacientes no período de 1998 a 2000, foram acompanhados neste período e avaliados do tempo de sobrevivência em meses, conforme o estadiamento clínico, tendo aplicado o teste Kruskal-Wallis. Resultado: Observou-se significância estatística ( $\mathrm{p}$-valor $<0,05)$ entre a média do Estadiamento II $(52,9 \pm 12,5$ meses $)$ e a do Estadiamento IIIb $(21,6 \pm 6,0$ meses); outro resultado significativo ( $\mathrm{p}$-valor $<0,05)$ foi observado entre o Estadiamento II $(52,9 \pm 12,5$ meses $)$ e o Estadiamento IV $(21,2 \pm 19,7$ meses). Conclusáo: Observamos melhor sobrevida em pacientes no estágio II. Entretanto, nos pacientes no estágio IV que apresentaram média de 21,2 meses de sobrevida, todos evoluíram a óbito até o final do estudo. O estágio I, por apresentar apenas um indivíduo, não foi representativo.
Análise da Distribuição quanto à Presença de Metástases em Pacientes Portadores de Carcinoma de Canal Anal, Tratados em Hospital de Referência Oncológica da Amazônia Oriental Hospital Ophir Loyola (HOL)

Soares PC, Lima IK, Souza AF, Ribeiro EKMA, Sena FG, Sousa RM Serviço de Cancerologia Cirúrgica, Hospital Ophir Loyola (HOL) - Belém (PA), Brasil

Objetivo: Apresentar estudo estatístico, com resultados da distribuição quanto à presença de metástases em pacientes portadores de neoplasia maligna de canal anal. Método: $O$ estudo foi constituído por 45 indivíduos, na faixa etária de 18 a 62 anos (média 48,5), portadores de carcinoma do canal anal, os quais foram atendidos segundo protocolo de diagnóstico e tratamento da Seçấo de Cirurgia Abdominopélvica do Serviço de Cancerologia do Hospital Ophir Loyola, Belém (PA) e submetidos ao estadiamento da doença através da realização de toque retal, exames laboratoriais, radiografia de tórax e tomografia computadorizada abdominal e pélvica. Após diagnóstico e estadiamento, foram encaminhados ao tratamento clássico do carcinoma de células escamosas do canal anal, constando de radioquimioterapia ou radioterapia exclusiva, associadas ou nấo à ressecção cirúrgica local ou ampliada, e colostomia quando indicada. Sendo realizada análise estatística com o teste do Qui-quadrado. Resultado: Dos 45 pacientes da amostra, foram encontrados 16 pacientes com presença de metástases (35,6\%), 28 pacientes $(62,2 \%)$ estavam livres de metástase, com p-valor: 0,0973. Apenas um doente com metástase não se pode classificar na amostra. Conclusáo: Concluímos que não houve significância quanto à presença de metástases em pacientes portadores de carcinoma de canal anal no presente estudo.

Estudo Epidemiológico Correlacionando estatisticamente a Resposta da Modalidade de Tratamento do Carcinoma de Canal Anal com a Sobrevida de Pacientes Atendidos em Hospital de Referência Oncológica da Amazônia Oriental Hospital Ophir Loyola (HOL)

Soares PC, Lima IK, Souza AF, Ribeiro EKMA, Sena FG, Sousa RM Serviço de Cancerologia Cirúrgica, Hospital Ophir Loyola (HOL) - Belém (PA), Brasil

Objetivo: Apresentar a análise estatística comparando o tratamento realizado com a sobrevida global de pacientes portadores de câncer de canal anal, tratados no Hospital Ophir Loyola, Belém (PA). Método: A amostragem tem 45 indivíduos atendidos no HOL, no período de 1998 a 2000, onde foram tratados com radioquimioterapia ou radioterapia exclusiva, associadas ou não à cirurgia. Sendo realizada análise estatística com o teste de Kruskal-Wallis. Resultados: Os indivíduos tratados com radioquimioterapia apresentaram um tempo de sobrevida maior $(47,8 \pm 14,9$ meses $)$. Entre aqueles que foram submetidos à cirurgia, o tempo médio de sobrevida foi de $43,7 \pm 21,7$ meses e os que fizeram radioterapia exclusiva tiveram sobrevida de $32,3 \pm 24,5$ meses. Teste de Kruskal-Wallis com p-valor=0,4945. Conclusão: $O$ tratamento radioquimioterápico apresentou melhor resposta quanto à sobrevida, em comparaçáo a outros métodos terapêuticos. Entretanto, ao realizar o teste estatístico, năo houve significância estatística entre todas as possíveis combinaçóes: p-valor $>0,05$. 
Estudo Estatístico Correlacionando a Distribuição de Metástase e a Sobrevida, em Pacientes Portadores de Câncer de Canal Anal, Tratados em Hospital de Referência Oncológica da Amazônia Oriental - Hospital Ophir Loyola (HOL)

Soares PC, Lima IK, Souza AF, Ribeiro EKMA, Sena FG, Sousa RM Serviço de Cancerologia Cirúrgica, Hospital Ophir Loyola (HOL) - Belém (PA), Brasil

Objetivo: Apresentar o estudo da distribuição de metástase e a sobrevida em pacientes portadores de câncer de canal anal, tratados no Hospital Ophir Loyola. Método: Foi constituído por 45 indivíduos, portadores de carcinoma do canal anal. Após estadiamento, foram encaminhados ao tratamento padrão da doença. Os pacientes que apresentaram metástases foram classificados de acordo com a localizaçáo, e realizado análise estatística com o teste de Kruskal-Wallis. Resultado: Do total, 15 apresentaram metástase. A sobrevida foi maior entre os indivíduos que apresentaram metástase locorregional, com 38,2 $\pm 18,8$ meses. Daqueles com metástase locorregional/visceral, a sobrevida foi de $28,3 \pm 24,0$ meses e, entre aqueles com alteração patológica na região visceral, a sobrevida foi de 10,5 $\pm 5,0$ meses. Conclusão: Concluímos que não houve significância estatística quanto à média da sobrevida em relação à distribuição da metástase, dos pacientes que foram submetidos a tratamento específico, independente do método terapêutico empregado.
Correlação dos pacientes Portadores de Carcinoma de Canal Anal que Apresentaram Recidiva Tumoral com a Incidência de Óbitos, Atendidos em Hospital de Referência Oncológica da Amazônia Oriental Hospital Ophir Loyola (HOL)

Soares PC, Lima IK, Souza AF, Ribeiro EKMA, Sena FG, Sousa RM Serviço de Cancerologia Cirúrgica, Hospital Ophir Loyola (HOL) - Belém (PA), Brasil

Objetivo: Apresentar os dados, correlacionando a recidiva do carcinoma de canal anal com a incidência de óbitos, em pacientes portadores dessa neoplasia maligna tratados no Hospital Ophir Loyola, Belém (PA). Método: A casuística foi constituída por 43 indivíduos portadores de carcinoma do canal anal, atendidos no HOL, no período de 1998 a 2000. Foram submetidos a estadiamento clínico e em seguida a tratamento padrão para a doença, constando de radioquimioterapia ou radioterapia exclusiva, associadas ou não a cirurgia. Resultados: Dentre os 43 pacientes tratados, 13 obtiveram recidiva do tumor; destes, oito evoluiram a óbito (61,5\%). Do total de dez óbitos (23,3\%), dois pacientes não apresentaram sinais de recidiva $(6,7 \%)$. Conclusão: Dos pacientes que apresentaram recidiva, a maioria evoluiu a óbito $(61,5 \%)$, confirmando a letalidade da doença nesse estágio; enquanto, daqueles que não apresentaram sinais de recidiva, apenas dois (6,7\%) evoluiram a óbito.
Distribuição Anual do Número de Casos Novos de Câncer Gástrico Diagnosticados em Hospital de Referência Oncológica da Amazônia Oriental, no Período de 2000 a 2005 - Hospital Ophir Loyola (HOL)

Lima IK, Souza AF, Ribeiro EKMA, Sena FG, Zacca FN, Aguiar Neto AF Serviço de Cancerologia Cirúrgica, Hospital Ophir Loyola (HOL) - Belém (PA), Brasil

Objetivo: Apresentar o número de casos novos de pacientes portadores de câncer gástrico e sua distribuição em relação aos anos de referido estudo, registrados no Hospital Ophir Loyola (HOL), Belém (PA), no período de 2000 a 2005. Método: Realizada coleta de dados através de prontuários dos pacientes cadastrados no Hospital Ophir Loyola, sendo conferidos apenas casos novos e confirmados de neoplasia maligna do estômago, no período de 2000 a 2005, e distribuída a sua incidência de acordo com os anos. Resultados: $\mathrm{O}$ número de casos novos registrados no período de 2000 foi de 127 casos (12,5\%); 2001, com total de 133 casos (13,1\%); 2002, com total de 192 casos (18,8\%); 2003, com total de 212 casos (20,7\%); 2004, total de 192 casos (18,8\%); e 2005, com total de 158 casos (15,4\%), totalizando 1.014 pacientes. Conclusão: Encontramos nesse período o total de 1.014 pacientes com câncer gástrico, sendo que no ano de 2003 obtivemos o maior número de casos com 212 pacientes e, no ano de 2000, o menor índice com 127 casos diagnosticados no Serviço de Cancerologia Cirúrgica do Hospital Ophir Loyola.
Estudo Epidemiológico Apresentando a Distribuição da Faixa Etária de Pacientes Portadores de Câncer Gástrico Atendidos em Hospital de Referência Oncológica da Amazônia Oriental - Hospital Ophir Loyola (HOL)

Lima IK, Souza AF, Ribeiro EKMA, Sena FG, Zacca FN, Aguiar Neto AF Serviço de Cancerologia Cirúrgica, Hospital Ophir Loyola (HOL) - Belém (PA), Brasil

Objetivo: Apresentar a distribuição de faixa etária de pacientes portadores de câncer gástrico, registrados no Hospital Ophir Loyola (HOL), no período de 2000 a 2005. Método: Realizada coleta de dados através de prontuários dos pacientes cadastrados no Hospital Ophir Loyola, Belém (PA), sendo conferidos apenas casos novos e confirmados de neoplasia maligna do estômago, no período de 2000 a 2005, distribuídos de acordo com a faixa etária. Resultado: No período estudado, foi encontrado, na faixa etária entre 15 a 30 anos, o total de 22 pacientes, o que corresponde a $2 \%$ da amostra; entre 30 a 40 anos, 57 pacientes (6\%); entre 40 a 50 anos, 169 pacientes (17\%); 50 a 60 anos, 223 pacientes (22\%); 60 a 70 anos, 297 pacientes (29\%); acima de 70 anos, 246 pacientes (24\%). Conclusáo: Encontramos nesse período o total de 1.014 pacientes com câncer gástrico, sendo observado um aumento importante do número de casos novos na faixa etária a partir dos 50 anos, com maior incidência entre 60 a 70 anos de idade, o que corresponde a dados obtidos na literatura científica. 
Fatores Associados a Complicações no PósOperatório de Cirurgias Oncológicas: Estudo CasoControle

Assis LCF, Sapucaia LM, Silva WP da, Ferreira KASL, Possari JF, Pollara W Instituto do Câncer do Estado de São Paulo (ICESP), São Paulo, Brasil; Universidade de Guarulhos-UnG; Faculdade de Medicina da Universidade de São Paulo

Introduçáo: Diversos fatores associam-se a complicaçōes no PósOperatório (PO) de cirurgias oncológicas. Objetivo: Identificar fatores associados à ocorrência de complicaçôes no PO no Instituto do Câncer do Estado de São Paulo (ICESP). Método: Os dados foram coletados a partir dos prontuários de cirurgias realizadas de março a agosto de 2009 de pacientes com idade $\geq 30$ anos. Resultados: Foram incluídos 106 pacientes, divididos em dois grupos: $43(40,6 \%)$ com complicaçóes e 63 $(59,4 \%)$ sem complicaçôes. No grupo com complicaçóes: $39,5 \%$ foram submetidos a cirurgias digestivas, $18,6 \%$ urológicas, $14 \%$ ginecológicas e 11,6\% mama. Complicaçôes observadas: $39,5 \%$ dor, $30,2 \%$ vômitos, 18,6\% infecção sistêmica e 16,6\% náusea, 16,3\% infecção local e 13,9\% hemorragia. Não houve diferença estaticamente significante entre grupos referente a: escolaridade; idade; IMC; presença de HAS, DM e outras comorbidades; uso contínuo de anti-inflamatórios não hormonais, opioides, antibióticos, insulina, diuréticos, anti-hipertensivos, digitálicos, anticoagulantes e fármacos para o tratamento da dislipidemia; uso de dispositivos: colostomia, ileostomia, fístula mucosa, dreno torácico, cateter venoso central de longa permanência, irrigaçáo vesical, SNG, SVD e SVA e cateter peridural. Conclusáo: Complicaçóes cirúrgicas aumentam a utilizaçấo de recursos hospitalares com consequente impacto nos custos.

41

\section{Câncer de Parótida Metastático de Pele: Relato de três Casos e Revisão de Literatura}

Loureiro AD, Castelo Branco MD de 0, Araújo KE, Andrade MR de, Vieira SA, Marchi MVD Universidade Federal da Paraíba, Hospital Napoleão Laureano

Introduçáo: Os tumores dermatológicos são a forma mais frequente de câncer. Geralmente sáo curáveis, contudo podem apresentar metástase. Linfáticos da regiāo parotídea, muitas vezes, são o primeiro sítio metastático das lesôes de face, regiáo anterior do couro cabeludo e orelha, gerando metástase parotídea. Não há comprovaçáo de quais fatores se relacionam com maior risco de acometimento parotídeo, não havendo evidências dos benefícios da ressecção profilática da glândula. Havendo acometimento, o prognóstico é reservado; tratamento cirúrgico e radioterapia adjuvante obtêm os melhores resultados. Objetivo: Relatar três casos de tumor de parótida metastático de pele. Metodologia: Avaliaçáo clínica, de prontuário e análise da literatura. Resultados: Masculino $54 a$, carcinoma sebáceo invasivo em pálpebra $D$. Encaminhada após seis meses, apresentando recidiva local e nódulo em parótida D. USG: nódulo sólido. Realizado parotidectomia e ressecção de lesão palpebral. Anatomopatológico: carcinoma sebáceo metastático em ambas as peças. TC após um mês mostrou processo expansivo comprometendo órbita ecavidades paranasaisà D. Submetida à Exenteraçăo orbitária (EO) e Radioterapia. Masculino, 40a, CEC em face há 1a. Evoluiu com lesáo ulcerada em região orbito-malar D. Submetida à EO. Anatomopatológico: CEC. Após 7m, evoluiu com nódulo em parótida. USG: nódulo sólido heterogêneo. Realizado Parotidectomia. Anatomopatológico: CEC. Realizado radioterapia e quimioterapia. Masculino, 64a, história de CBC em nariz e orelha $E$ há seis anos. Recidiva em orelha $\mathrm{E}$ com comprometimento da regiâo parotídea. Indicado Parotidectomia. Anatomopatológico: CBC. Realizado radioterapia. Conclusáo: Tumor de parótida metastático de pele se relaciona com pior prognóstico. Atualmente, não há evidências de quais pacientes se beneficiariam da ressecção profilática da glândula. Estudos que identifiquem preditores do acometimento parotídeo são necessários.
Prevalência de Complicaçôes no Pós-Operatório de Cirurgias no Instituto do Câncer do Estado de São Paulo

Silva WP da, Santos SB, Andrade D, Ferreira KASL, Possari JF, Pollara W Instituto do Câncer do Estado de São Paulo (ICESP); Universidade de Guarulhos-UnG; Faculdade de Medicina da Universidade de São Paulo

Objetivo: Identificar prevalência de complicaçóes no Pós-Operatório (PO) em pacientes submetidos a cirurgias oncológicas realizadas no ICESP. Método: Dados coletados nos prontuários e no sistema de informaçóes hospitalares, marçoagosto de 2009. 1.423 cirurgias, sendo que 3,2\%(n=45) tiveram complicaçôes. No total de cirurgias, a prevalência de complicaçóes por especialidade foi: nas neurocirurgias $(\mathrm{NC}) 15,4 \%(\mathrm{n}=2)$, vasculares $10 \%(\mathrm{n}=2)$, gastrointestinais $(\mathrm{GI})$ $7,1 \%(n=17)$, ginecológicas $(\mathrm{GO}) 4,5 \%(\mathrm{n}=6)$, tórax $(\mathrm{TO}) 4 \%(\mathrm{n}=2)$, cirurgias plásticas 2,4\%(n=2), cabeca e pescoco $(C P) 2,3 \%(n=3)$, na mastologia (MA) $2 \%$ $(\mathrm{n}=5)$ e urologia $(\mathrm{URO}) 1,6 \%(\mathrm{n}=8)$. Em relaçấo às comorbidades: $40 \%(\mathrm{n}=18)$ tinham HAS e $13,3 \%$ DM. Complicaçóes: dor $(40 \%, n=18)$, principalmente na GI, TO e MA; infeccáo local $(17,8 \%, n=8)$, GO, TO, GI, MA e NC $(\mathrm{p}=0,034)$; infecção sistêmica $(17,8 \%, \mathrm{n}=8)$, predomínio na URO; constipaçấo $(13,3 \%, \mathrm{n}=6)$, frequente na GI e URO; anemia $(8,9 \%, \mathrm{n}=4)$, mais frequente na URO; choque hipovolêmico $(6,7 \%, \mathrm{n}=3)$, observado URO, GI e GO; deiscência $(8,9 \%, \mathrm{n}=4)$, na GO, MA e NC; choque séptico $(8,9 \%, \mathrm{n}=4)$, observado na GI, $\mathrm{NC}$ e TO; hemorragia $(13,3 \%, \mathrm{n}=6)$, na URO, $\mathrm{TO}$ e $\mathrm{CP}(\mathrm{p}=0,023)$; vômitos $(28,9 \%, \mathrm{n}=13)$, MA, URO, GI e GO; TVP $(8,9 \%, \mathrm{n}=4)$ ocorrendo em GI, TO e URO $(\mathrm{p}=0,045)$. Maioria homens $(51,1 \%, \mathrm{n}=23)$, adultos $(60 \%, \mathrm{n}=27)$ eobesos (IMC $\geq 31)(82,2 \%), 40 \%(n=18)$ tinham HAS e 46,7\%(n=21) tinham metástases. Mobilidade: $17,8 \%(\mathrm{n}=8)$ acamados e $20 \%$ deambulavam com auxílio. Hábitos: 11,1\%(n=5) tabagistas e 2,2\% etilistas. Idade média 58,16 anos ( $\mathrm{DP}=12,75)$. Tempo médio de permanência 11,6 dias ( $\mathrm{DP}=11,8$, mediana=7). Nos doentes complicados, houve $20 \%$ de óbitose $17,8 \%$ foram encaminhados para UTI. Conclusáa: As complicaçôes foram dor, infecção e vômitos, mais prevalentes na neurocirurgia e cirurgia digestiva, principalmente em pacientes idosos, homens, obesos, hipertensos e diabéticos.

42

\section{Carcinoma Neuroendócrino do Retroperitônio: Relato de Caso}

Loureiro AD, Lima IAB de, Guerra DV, Paiva ARQ de, Mello FST de, Leite CRC Universidade Federal da Parába, Hospital Napoleão Laureano

Introduçáo: $\mathrm{O}$ tumor neuroendócrino é uma neoplasia rara, capaz de produzir, armazenar e secretar neuropeptídeos funcionantes ou não. Contudo, muitas vezes, a sintomatologia se expressa apenas pelo tamanho da lesão. Tem crescimento lento, dificultando o diagnóstico em fases iniciais. Tumores originados em sítios distintos diferem quanto à função, histologia e ao comportamento. $\mathrm{O}$ tratamento é controverso preconizando-se ressecção com margens amplas. Objetivo: Avaliaçáo de prontuário de paciente do Hospital Napoleão Laureano, João Pessoa (PB). Metodologia: Relato de caso a partir de avaliaçăo clínica, cirúrgica e análise de prontuário de paciente atendido no Hospital Napoleão Laureano. Resultados: Paciente 70 anos, masculino, com lombalgia há seis meses. TC abdominal revelou processo expansivo retroperitoneal, anterior ao rim direito, $\mathrm{com} 4 \mathrm{~cm}$ de diâmetro. EDA, colonoscopia, CEA, afetoproteína e CA 19-9 sem anormalidades. Foi realizada ressecçăo da massa, sem intercorrências no pós-operatório. Perfil imunoistoquímico revelou cromogranina positiva e 35BH11 e $34 \mathrm{BE} 12$ negativas, confirmando diagnóstico de carcinoma neuroendócrino pouco diferenciado. Um mês após, o paciente evoluiu com dor lancinante e dificuldade para deambular. Ressonância Magnética evidenciou metástase vertebral, sendo instituída quimioterapia com Etoposide e Ifosfamida e Radioterapia locorregional, com melhora significativa. No momento, encontra-se assintomático, sem evidência clínica e radiológica de doença em atividade. Conclusão: $\mathrm{O}$ carcinoma neuroendócrino é uma entidade rara, principalmente em retroperitônio. Nesta localização, o tamanho determina a sintomatologia e o diagnóstico tardio, favorecendo a recorrência e metástase. A cirurgia parece ser a melhor terapêutica. 
Tumor de Papila Duodenal: Relato de Caso

Loureiro AD, Castelo Branco MDO, Oliveira LS, Lima IAB de, Mello FST de, Leite CRC Universidade Federal da Paraíba, Hospital Napoleão Laureano

Introduçáo: As neoplasias de papila duodenal são raras, representando $7 \%$ a $12 \%$ dos tumores periampulares; ocorrem mais frequentemente entre 50 e 70 anos. Acometimento pancreático e, em estágios avançados, vasos mesentérios superiores e veia porta são comuns; os linfonodos estâo comprometidos em mais de $50 \%$ dos casos. Os sintomas manifestam-se mais precocemente do que em neoplasias pancreáticas, devido à obstrução do sistema biliar, sendo o principal a icterícia. A duodenopancreatectomia com ou sem preservação pilórica, é a opção potencialmente curativa. Objetivo: Relatar caso de neoplasia de papila, com diagnóstico e instituição do tratamento tardio. Metodologia: Avaliação de prontuário do paciente do Hospital Napoleão Laureano, João Pessoa (PB). Resultados: Feminino 42 anos, com icterícia $(3+/ 4+)$, astenia, perda ponderal $(30 \mathrm{Kg} / 9 \mathrm{meses})$, prurido, anemia e dezenas de hemotransfusóes. Tratada como hepatopatia viral por seis meses; realizada histerectomia, admitindo-se ser leiomioma uterino sangrante a causa da anemia. Tomografia evidenciou dilatação das vias biliares intra e extra-hepáticas e aumento do volume da cabeça do pâncreas. CA 19-9 foi 12,9U/mL, com enzimas canaliculares elevadas; endoscopia mostrou lesão vegetante ulcerada em papila duodenal. Realizada gastroduodenopancreatectomia, sem intecorrências. No terceiro DPO, encontrava-se sem icterícia. Anatomopatológico revelou adenocarcinoma de papila com $8,0 \mathrm{~cm}$, margens livres, infiltrando pâncreas, sem comprometimento linfonodal. Encaminhada à oncologia clínica para tratamento complementar. Conclusáo: A equivocada condução terapêutica prévia - histerectomia - retardou o diagnóstico oncológico, determinando um tratamento cirúrgico radical para uma lesão T4 (TNM) de papila duodenal. 45

\section{Câncer Colorretal Sincrônico Triplo em Adulto Jovem: Relato de Caso}

Nascimento RS, Fernandes PHS, Gomes HL, Rezende SMV, Lopes DLG, Lima TC Hospital de Clínicas da Universidade Federal de Uberlândia (HCUFU)

Introduçáo: Neoplasia maligna mais comum do tubo digestivo, o câncer colorretal teve sua incidência aumentada nos últimos anos, sendo a quarta mais comum no mundo. Mais frequente após a sexta década de vida, $90 \%$ dos casos em pacientes com mais de 50 anos. Há uma ocorrência significante dos tumores colorretais sincrônicos descrita na literatura. Objetivos: Relatar o caso de uma paciente com três tumores malignos sincrônicos em cólons direito e esquerdo. Discussáo: Paciente do sexo feminino, 43 anos, com dor abdominal difusa há oito meses, principalmente em quadrante inferior esquerdo, com piora ao alimentar. Apresentava náuseas, vômitos, enterorragia, hiporexia e astenia. Emagrecimento de 18 quilos em oito meses. Colonoscopia parcial revelou lesão vegetante, infiltrativa, friável e com sangramento em cólon esquerdo, não permitindo a passagem do aparelho. Submetida à laparotomia exploradora, verificou-se presença de três grandes massas $(8 \mathrm{~cm}$ de diâmetro cada) em ceco, ângulo esplênico e cólon esquerdo. Realizada colectomia total, poupando o reto, anastomose ileorretal e linfadenectomia. Anatomopatológico evidenciou adenocarcinoma pouco diferenciado, invadindo até serosa de ceco e cólons, sem metástases para linfonodos e margens de ressecçáo livre. Três meses após cirurgia, paciente encontra-se em tratamento quimioterápico com evolução favorável. Conclusáo: A ocorrência de carcinomas sincrônicos reforça a importância do estudo endoscópico pré-operatório completo do cólon associado à minuciosa palpação intraoperatória. Diante do achado descrito, a realizaçáo de colectomia total ou subtotal deve ser considerada a fim de extirpar o intestino potencialmente carcinogênico.
Fatores Prognósticos do Câncer de Boca em Estádio Inicial

Barreto Jr. JV, Teodoro F, Mano JB, Boldrini Jr. D, Santos CR, Carvalho AL Hospital de Câncer de Barretos - Barretos (SP), Brasil

Introduçáa: $\mathrm{O}$ câncer de boca é a neoplasia mais frequente da cabeça e pescoço e as recidivas locorregionais são as causas mais comuns de falha no tratamento inicial, e ocorrem em torno de $30 \%$ a $50 \%$ dos pacientes. Objetivo: Avaliar os fatores prognósticos dos pacientes em estádios iniciais (I e II) de câncer de boca. Material e Métodos: Estudo retrospectivo com 215 pacientes com carcinoma de cavidade oral, estádio clínico I e II, tratados no Hospital de Câncer de Barretos. Foram levantados dados sobre epidemiologia, fatores de risco, tratamento inicial, recidiva, tratamento da recidiva e sobrevida. Resultados: A relação entre homens e mulheres foi 3:1, os tabagistas representavam $78,9 \%$, e $66,3 \%$ eram etilistas. O tratamento cirúrgico foi realizado em $80,9 \%$ dos casos e $37,4 \%$ fizeram radioterapia pós-operatória. Durante o seguimento, $29,4 \%$ pacientes apresentaram recorrência, sendo $14,0 \%$ recidivas locais e $14,4 \%$ recidivas no pescoço e $3,3 \%$ recidivas locorregionais. A sobrevida global, em cinco anos, dos pacientes foi de $63,4 \%$. Os pacientes submetidos à cirurgia tiveram uma sobrevida, em cinco anos, de $68,6 \%$ e os submetidos à radioterapia de $47,3 \%(\mathrm{p}=0,014)$. Nos casos cirúrgicos, a sobrevida em cinco anos foi de $75,6 \%$ para os casos T1 e de 59,6\% para os T2 ( $\mathrm{p}=0,046)$; para os pacientes com margem comprometida foi de 51,4\%, e com margens livres $68,6 \%(\mathrm{p}=0,035)$. Conclusáo: Pacientes com tumor inicial da cavidade oral apresentam um melhor prognóstico quando submetidos a tratamento cirúrgico. Nos casos cirúrgicos, a classificação $\mathrm{T}$ e a avaliaçáo histológica das margens apresentaram diferenças significativas no prognóstico.

46

\section{GIST: Três Casos de Diagnóstico após Ressecção}

Fernandes PHS, Nascimento RS, Gomes HL, Borges EB, Rezende SMV, Lopes DLG Hospital de Clínicas da Universidade Federal de Uberlândia (HCUFU)

Introdução: Os tumores estromais do trato gastrointestinal (GIST) são neoplasias mesenquimatosas raras provenientes das células intersticiais de Cajal, 95\% com expressão do gene c-KIT (CD117). Objetivo: Relatar três casos de GIST com diagnóstico após ressecção, operados no HCUFU, de 2008 a 2009. Discussáo: R.F.S., mulher, 55 anos, com epigastralgia e emagrecimento, com TC identificando massa em corpo de pâncreas, mas o achado intraoperatório foi de tumoraçáo duodenal, no nível do ângulo de Treitz (4,5 × 4 × $3 \mathrm{~cm})$. Anatomopatológico (AP) confirmou GIST de baixíssimo grau proliferativo. N.A.A., mulher, 31 anos, com melena e endoscopia digestiva alta com lesão elevada em transição corpo-antro gástrico, de aspecto submucoso, com biópsia negativa para malignidade, submetida à laparotomia com excisão em cunha da lesão $(2,5 \times 2,0$ x 1,8 cm). AP compatível com GIST, padrão epitelioide benigno, porém, à imunoistoquímica, com c-KIT negativo e compatibilidade com vimentina e actina de músculo liso. A.F.R., homem, 55 anos, com vômitos, perda ponderal e TC com massa abdominal bem delimitada, com achado laparotômico de tumoraçâo em delgado, $70 \mathrm{~cm}$ do ângulo de Treitz $(8,2 \times 6,5 \times 5,5 \mathrm{~cm})$, AP compatível com GIST de risco intermediário (4 mitoses $/ 50$ campos) com c-KIT positivo. Conclusáo: Tipo incomum de tumor gastrointestinal, o relato de três GISTs operados em um ano revela sua importância, além do raro caso c-KIT negativo. Após a ressecção, o seguimento ambulatorial se faz mister, pois o risco de recorrência alcança $50 \%$ em cinco anos e o uso do quimioterápico Imatinib pode estar indicado. 


\section{Carcinoma de Paratireoide: Relato de Caso}

Araúio ALM, Ghetti TM, Gonçalves MDC, Lázaro APP, Vasconcelos RD Hospital Universitário Clementino Fraga Filho (HUCFF/UFRJ) - Rio de Janeiro (RJ),

Introduçáo: $\mathrm{O}$ carcinoma de paratireoide é uma neoplasia rara, na qual há acometimento ósseo em $90 \%$ dos casos (osteíte fibrosa cística, reabsorção subperiosteal, osteopenia difusa). Malignidade é dada pela invasão angioneural ou de estruturas adjacentes e/ou presença de metástases a distância, principalmente para pulmão. $\mathrm{O}$ tratamento é sempre cirúrgico, com retirada em bloco do tumor. Não existem quimioterápicos disponíveis. Objetivo: Relatar o primeiro caso de carcinoma de paratireoide operado no Hospital Universitário Clementino Fraga Filho. Métodos: Revisão dos dados de prontuário do paciente. Resultados: Paciente C.A.R., 47 anos, masculino, pardo, residente em Bonsucesso (RJ). Referia dor lombar e em membros inferiores, simétrica, que piorava com movimentação. Tomografia Computadorizada de Coluna Lombar revelou lesōes líticas na asa do ilíaco e corpo de L5. Diagnosticado hiperparatireoidismo primário, realizouse paratireoidectomia superior esquerda, em outra instituiçáo. Laudo histopatológico: adenoma de paratireoide. No pós-operatório, mantinha níveis elevados de PTH. Radiografia de esqueleto com áreas de aspecto de osso lavado em fêmur e tíbia, reabsorçáo subperiosteal em falanges distais de máos e de terço distal de clavículas. Coluna lombar com osteopenia difusa. Realizada reintervençáo cirúrgica, com paratireoide inferior direita aumentada, firmemente aderida ao nervo laríngeo recorrente. Laudo histopatológico: carcinoma de paratireoide com células oxifílicas, infiltração adjacente, invasão vascular e perineural. Pós-operatório evoluiu com hipoparatireoidismo, hipocalcemia e fósforo normal, com melhora após reposição de vitamina $\mathrm{D}$ e carbonato de cálcio oral. O carcinoma de paratireoide é uma neoplasia rara, de tratamento cirúrgico e difícil manejo clínico. É necessário o diagnóstico de um patologista experiente. Não existe tratamento adjuvante bem definido. 49

\section{Sarcoma de Bexiga: Relato de Caso}

\section{Oliveira BRR, Kansaon MJM, Santos FAV, Wainstein AJA, Cabral WLR, Lacerda LT Instituto Mário Penna - Belo Horizonte (MG), Brasil}

Introdução: Os sarcomas de bexiga são tumores extremamente raros e representam $0,3 \%$ de todas as neoplasias malignas do órgão. São muito agressivos mais frequentes em homens na sexta década de vida e coincide com os carcinomas uroteliais. Não está definida uma relação causaefeito. Sinais e sintomas incluem hematúria franca dolorosa, urgência, noctúria, retenção urinária e infecção urinária recorrente. Cistectomia radical é o tratamento de escolha com altas taxas de recorrência após a cirurgia. Radioterapia adjuvante e vários esquemas de quimioterapia têm resultados inconsistentes. Relato de caso: VS, 54 anos, evoluindo há dois anos com astenia e tumoração em hipogástrio. Biópsia com imunoistoquímica demonstrou tumor de bexiga, leiomiossarcoma de grau intermediário. Ao exame físico, tumor palpável em todo andar inferior do abdômen, estendendo-se até região de hipocôndrio direito. Realizada Tomografia Computadorizada de abdômen para estadiamento. Evoluiu no pré-operatório com insuficiência renal pós-renal, realizada nefrostomia direita. Optou-se por tratamento cirúrgico paliativo, realizada cistectomia radical, nefrostomia aberta à direita, ureterostomia cutânea à esquerda, colocação de duplo J à esquerda, apendicectomia e orquiectomia direita. Evoluiu satisfatoriamente no pós-operatório. Conclusáo: A cirurgia é o único tratamento com possibilidade de cura para o leiomiossarcoma de bexiga, sendo também indicada com o objetivo de paliação da doença.

\section{Tumor de Frantz: Relato de um Caso}

Fernandes PHS, Rezende SMV, Lopes DLG, Gomes HL, Figueiredo PAKN Hospital de Clínicas da Universidade Federal de Uberlândia (HCUFU)

Introduçáo: $\mathrm{O}$ Tumor de Frantz ou neoplasia sólida-cística papilar do pâncreas é pouco frequente (menos de $2 \%$ das neoplasias pancreáticas), com baixo potencial de malignidade e etiopatogenia desconhecida. Ocorre em mulheres jovens, com bom prognóstico, mesmo quando invasivo localmente ou com metástases. Apresenta-se como massa abdominal de crescimento lento. Objetivos: Relatar um caso de tumor de Frantz. Discussáo: Paciente de 48 anos, mulher, com dor abdominal esporádica em flanco direito há sete meses. Ultrassonografia abdominal evidenciou imagem arredondada hipoecogênica (sólida) em cabeça do Pâncreas. TC revelou formação expansiva heterogênea acometendo a cabeça pancreática, medindo $3,6 \times 3,0 \mathrm{~cm}$, com realce irregular e com sinais de preenchimento tardio no interior, com áreas hipoatenuantes irregulares de permeio, discreto grau de dilatação de vias biliares à montante. CEA 0,60 ng/ml. Realizada laparotomia que evidenciou lesão sólida restrita à cabeça do pâncreas, procedendo à duodenopancreatectomia (operaçáo de Whipple). O exame anatomopatológico sugeriu adenocarcinoma pancreático misto, sólido-cístico, focalmente mucossecretor, mostrando áreas papilíferas; eo estudo imunoistoquímico confirmou neoplasia sólido-cística papilar do pâncreas. Paciente no quarto mês pós-operatório apresentava-se em bom estado geral, mantendo acompanhamento clínico. Conclusáo: É importante considerar o tumor de Frantz no diagnóstico diferencial de massa abdominal em mulheres jovens. O tumor de Frantz, por ser de baixo potencial maligno, deve ser tratado com ressecçóes pancreáticas conservadoras ou radicais, visto que o tratamento cirúrgico pode promover a cura.

\section{Plasmocitoma Hepático: Raro Diagnóstico Diferencial dos Nódulos Hepáticos}

Santos FAV, Wainstein AJA, Kansaon MJM, Oliveira BRR, Lacerda LT ONCAAD - BIOCANCER

Introdução: Os nódulos hepáticos são, frequentemente, fonte de preocupação para cirurgióes, oncologistas e para os próprios pacientes. Com a utilizaçáo crescente da ultrassonografia abdominal, é cada vez mais comum a detecçáo de lesôes nodulares do fígado. Nestas circunstâncias, deve-se prosseguir com a dosagem sérica dos marcadores tumorais, principalmente CEA, CA 19-9 e alfafetoproteína; realização de tomografia abdominal e, não infrequentemente, de biópsia percutânea da lesão. Relato de caso: Relatamos o caso de paciente do sexo feminino, 72 anos, oligossintomática, submetida à ultrassonografia abdominal devido a sintomas de dispepsia e dolorimento abdominal de início recente. Notada a presença de lesão nodular de aproximadamente $4,0 \mathrm{~cm}$ de diâmetro no segmento III hepático. À tomografia abdominal, percebia-se lesão. Os marcadores tumorais séricos foram normais e, a princípio, tratava-se de adenoma hepático. Procedido com laparotomia e ressecçáo do segmento III do fígado. A evolução pós-operatória foi satisfatória. O resultado da avaliaçấo histológica e imunoistoquímica foi de plasmacitoma hepático. Na propedêutica subsequente, confirmou tratar-se de acometimento isolado do fígado. Conclusão: Nódulos hepáticos são frequentemente diagnosticados à ultrassonografia abdominal realizada para o esclarecimento de sintomas abdominais vagos. Deflagram extenso processo de propedêutica e que, em algumas circunstâncias, culmina com o tratamento cirúrgico. Apesar de raro com poucos casos relatados na literatura, os plasmocitomas isolados do fígado devem ser considerados como diagnóstico diferencial dos nódulos hepáticos. 
Hemangioma Hepático Gigante: Relato de Quatro Casos

\author{
Santos FAV, Wainstein AJA, Kansaon MJM, Oliveira BRR, Lacerda LT \\ ONCCAD- BIOCANCER
}

Introduçáo: Os hemangiomas hepáticos são os tumores benignos primários do fígado mais comuns. São, na maioria das vezes, clinicamente indolentes, diagnosticados casualmente à ultrassonografia abdominal e têm dimensóes de poucos centímetros. Quando ultrapassam $4 \mathrm{~cm}$ são classificados como hemangiomas gigantes e, nesta situaçáo, podem ocasionar alteraçóes clínico-laboratoriais, tais como: dor abdominal, icterícia obstrutiva, trombocitopenia, hemólise e ruptura tumoral com abdômen agudo hemorrágico. Relato de caso: Relatamos quatro casos de pacientes com diagnóstico clínico e radiológico de hemangioma hepático. Sendo três casos do sexo feminino, e a idade mínima foi de 36 anos e a máxima foi de 59 anos. $\mathrm{O}$ diâmetro tumoral médio foi de $13 \mathrm{~cm}$ e, em dois casos, ocupavam todo o lobo direito do fígado. Em três casos, eles se localizavam no lobo direito hepático. A manifestação clínica mais comum foi a dor abdominal em andar superior do abdômen associada a sintomas compressivos gástricos. Um paciente evoluía com quadro de colangite recorrente. $\mathrm{O}$ tratamento foi a ressecção cirúrgica em todos os casos e não houve necessidade de transfusão sanguínea em nenhum deles. Conclusão: Na maioria das vezes, a observação clínica é a única medida recomendada para o tratamento dos hemangiomas hepáticos. Porém, nos hemangiomas gigantes, a ressecção cirúrgica é necessária para o controle dos sintomas. A despeito do efeito de massa promovido por essas lesóes, a operaçấo é realizada com segurança em plano de clivagem entre o tecido hepático normal e o tumor e, excepcionalmente, é necessário transfusão de hemácias.

\section{Prognóstico de Pacientes Portadores de Câncer de Orofaringe em Estádios Iniciais com Tratamento Baseado em Cirurgia ou Radioterapia}

Barbieri F, Santos C R, Mano JB, Boldrini DJ, Barreto JV, Carvalho AL Hospital de Câncer de Barretos - Barretos (SP), Brasi

Introduçáo: $\mathrm{O}$ câncer de orofaringe é um tumor maligno de alta agressividade, sendo o carcinoma epidermoide o tipo histológico preponderante. Objetivos: Avaliar o desfecho de pacientes com câncer de orofaringe (estádios clínicos I e II) tratados com terapia baseada em cirurgia ou radioterapia. Material e Método: Estudo de coorte, retrospectivo, avaliando pacientes tratados no H.C. de Barretos, no período de 2000 a 2008. A coleta de dados foi baseada em formulário que contemplava características demográficas, clínicas e de terapêutica empregada. Para análise dos dados, foi utilizada a estatística descritiva, sendo a análise de sobrevida global e livre de doença calculadas pelo método Kaplan-Meier. Para comparação das curvas, o método log-rank. Foram considerados significativos valores de $\mathrm{p}<0,05$. Resultados: Oitenta e cinco pacientes foram incluídos no estudo. A maioria era do sexo masculino $(85,9 \%)$, tabagistas $(90,6 \%)$ e etilistas $(68,2 \%)$. Vinte e dois pacientes foram estadiados como T1 $(25,9 \%)$ e 63 como T2 (74,1\%). O tratamento radioterápico foi realizado em 51 pacientes $(60,0 \%)$ e o cirúrgico em 34 pacientes $(40,0 \%)$, sendo que $41,2 \%$ destes receberam radioterapia pós-operatória. A sobrevida global em cinco anos foi de $63,4 \%$. Considerando-se o tratamento realizado, os pacientes submetidos ao tratamento cirúrgico apresentaram uma sobrevida em cinco anos de $70,7 \%$ e os pacientes submetidos à radioterapia, $58,9 \%(\mathrm{p}=0,321)$. A sobrevida também não esteve associada ao estádio $\mathrm{T}$ (T1 - 63,4\% versus T2 - 63,5\%; $\mathrm{p}=0,525)$. Conclusáo: Mesmo em estádios iniciais, a neoplasia maligna de orofaringe apresenta-se de forma agressiva e o prognóstico não foi influenciado pelo estádio $T$ ou o tratamento realizado.
Angiomiolipoma Hepático: Diagnóstico Diferencial do Hepatocarcinoma e Sarcoma Hepático

Santos FAV, Wainstein AJA, Kansaon MJM, Oliveira BRR, Lacerda LT ONCCAD - BIOCANCER

Introduçáo: $\mathrm{O}$ angiomiolipoma hepático é afecção rara, derivado de células mesenquimais, composto por gordura, musculatura lisa e elementos vasculares, sendo de ocorrência bem menor do que os angiomiolipomas renais.Na maioria das vezes, seu diagnóstico é ocasional. Relato de caso: Relatamos o caso de paciente do sexo feminino, 56 anos de idade, evoluindo ao longo de meses com peso pós-prandial, pirose e desconforto epigástrico. Havia elementos clínicos e laboratoriais de cirrose hepática. Ao exame físico, notava-se massa palpável em hipocôndrio direito e epigástrio. Avaliada por meio de ultrassonografia e tomografia helicoidal abdominais, com achados de massa hiperecogênica ao primeiro método e lesão com vascularização irregular e presença de conteúdo de baixa densidade (gordura) em seu interior, de aspecto pediculado, acometendo segmento III do fígado com aproximadamente $20 \mathrm{~cm}$ de diâmetro. Os marcadores tumorais séricos eram normais. Submetida à segmentectomia hepática, segmento III, sem intercorrências. A evolução pós-operatória foi satisfatória. O resultado da avaliaçáo histológica e imunoistoquímica foi de angiomiolipoma hepático. Conclusão: $\mathrm{O}$ angiomiolipoma hepático é tumor gorduroso do fígado benigno, usualmente de curso clínico indolente e que pode atingir grandes dimensōes. Pela presença de gordura nos hepatocarcinomas e sarcomas hepáticos, faz-se necessária a diferenciação diagnóstica com essas afecções. Na dúvida diagnóstica e na presença de sintomas relacionados com o tumor, especialmente por compressão de estruturas vizinhas, a ressecção cirúrgica está indicada.

54

\section{Tumor Desmoplásico de Pequenas Células Redondas Intra-Abdominais: Relato de Caso}

Fernandes PHS, Rezende SMV, Lopes DLG, Figueiredo PAKN, Gomes HL Hospital de Clínicas da Universidade Federal de Uberlândia (HCUFU)

Introduçáo: Neoplasia de descoberta recente e com poucas centenas de casos descritos na literatura mundial, o tumor desmoplásico de pequenas células redondas intra-abdominal tipicamente ocorre em crianças e adultos jovens do sexo masculino, associado a mau prognóstico. Objetivos: Relatar um caso de tumor desmoplásico de pequenas células redondas intra-abdominal. Discussáo: Paciente do sexo masculino, 38 anos, com perda de $8 \mathrm{Kg}$ em oito meses, apresentando volumosa tumoração endurecida, aderida a planos profundos, dolorosa à palpaçáo, em andar superior do abdômen, confirmada por ultrassonografia, ressonância magnética e angiorressonância. Submetido à cirurgia citorredutora com ressecçáo de massa de maior volume, esplenectomia, omentectomia e múltiplas biópsias de vários nódulos menores disseminados. $\mathrm{O}$ exame anatomopatológico sugeriu e o estudo imunoistoquímico confirmou tumor desmoplásico de pequenas células redondas invadindo tecido adiposo dos órgãos adjacentes, estádio IV. Encaminhado para complementação terapêutica com quimioterapia, no oitavo mês de pós-operatório com massa residual palpável em hilo esplênico e surgimento de nova tumoração em hilo hepático confirmada por ressonância magnética. Conclusăo: Com diagnóstico firmado pelo estudo imunoistoquímico, o tumor desmoplásico de pequenas células redondas intra-abdominal tem evoluçáo extremamente desfavorável, apresenta dois padrōes de acometimento na maioria dos casos: vários nódulos aderidos à superfície peritoneal ou massa dominante circundada por múltiplos nódulos satélites menores preenchendo a cavidade peritoneal. Não apresenta boa resposta à quimioterapia e radioterapia, reservando 17 meses de sobrevida média na maioria das séries descritas e sendo o comprometimento abdominal maciço a principal causa de morte. 
Hemangiopericitoma Pélvico: Relato de Caso

\section{Santos FAV, Wainstein AJA, Kansaon MJM, Oliveira BRR, Parreiras FC ONCCAD - Belo Horizonte (MG), Brasil}

Introdução: $\mathrm{O}$ hemangiopericitoma é tumor proveniente das células mesenquimais, consideradas precursoras das células endoteliais. São lesōes hipervascularizadas, raras e que acometem ambos os sexos. Podem, em algumas circunstâncias, apresentar comportamento maligno. Relato de caso: Relatamos o caso de paciente do sexo feminino, 51 anos de idade, evoluindo com dolorimento pélvico e certo desconforto evacuatório. Em ultrassonografia abdominal, notava-se volumosa lesão em pelve menor, hipervascularizada ao doppler, confirmada à ressonância magnética, e que promovia deslocamento lateral do reto. Submetida à ressecçáo completa da lesão e não se observou invasão direta de nenhum órgão pélvico. Devido ao seu caráter hipervascular e, principalmente, pela presença de varizes pélvicas decorrentes da compressão tumoral local, ocorreu sangramento aumentado no peroperatório com repercussão hemodinâmica, tratado com reposiçấo volêmica, hemotransfusão e colocaçáo de compressas na pelve. A paciente foi reoperada 48 horas depois, em fase de estabilidade clínica, e náo havia nenhuma fonte de sangramento em atividade. Conclusáo: $\mathrm{O}$ hemangiopericitoma é tumor raro, pode assumir comportamento maligno em algumas situações e, portanto, é mandatório acompanhamento seriado dos pacientes. A ressecçáo cirúrgica completa da lesão é o tratamento de escolha e, devido ao risco de sangramento peroperatório, pode-se associar radioterapia pré-operatória para reduçáo da vascularizaçáo e dimensão tumoral.

\section{Análise Retrospectiva dos Tumores de Órbita e Olho Atendidos no Hospital Napoleão Laureano}

\section{Vieira SA, Loureiro AD, Carlos GMB, Serrano NNM, Castelo Branco MD de 0, Marchi MVD Universidade Federal da Parába, Hospital Napoleão Laureano}

Introduçáo: Os tumores do bulbo ocular e órbita podem ser benignos ou malignos, intra e extraoculares. A investigaçáo local é voltada para o sítio primário da lesão. O tratamento é baseado no estadiamento e deve considerar a facilidade de remoção cirúrgica e o grau de sensibilidade à quimio e radioterapia. Objetivo: Traçar perfil clínico e epidemiológico dos casos de câncer de órbita e olho do Hospital Napoleão Laureano, João Pessoa (PB). Metodologia: Análise de nove casos de tumor de órbita e globo ocular, atendidos em janeiro de 2005 a dezembro de 2009. Resultados: Dos nove prontuários, 33\% eram de homens, 33\% mulheres e três não identificados. Idade entre 40 a 69 anos. Queixa principal: Tumoração na regiấo orbitária em sete $(77 \%)$ pacientes. Um paciente apresentou déficit visual e em um prontuário não havia esse dado. O olho mais atingido foi o direito (77\%). Tipos mais comuns: carcinoma espinocelular (2 casos), linfoma nâo hodgkin tipo b (2), carcinoma sebáceo superficial (1), carcinoma basocelular de pálpebra (1), metástase de tumor de parótida (1) e melanoma de coroide (1). Um dos casos não foi definido pelo anatomopatólogico. Condutas cirúrgicas: excisão de lesão palpebral para o carcinoma basocelular; excisão de lesão intraorbitária para o linfoma năo Hodgkin; esvaziamento orbitário para o carcinoma espinocelular; enucleação para o tumor de parótida e exenteração para o melanoma e carcinoma sebáceo superficial invasivo. Conclusão: Neste trabalho, há dados semelhantes a vários casos na literatura, nos quais os tumores mais comuns são os primários (epidermoide e linfoide). A idade prevalece na década de 40.
Utilização de um Sistema de Rastreabilidade de Instrumental Cirúrgico: Experiência do Instituto do Câncer do Estado de São Paulo (ICESP)

Heringer R, B Neto S, Silva EA, Possari JF, Baia WRM Instituto do Câncer do Estado de São Paulo (ICESP) - São Paulo (SP), Brasil

Introdução: Tecnologias de Gerenciamento de Instrumentais Cirúrgicos (IC) vêm sendo adotados no Centro de Material e Esterilização (CME) para garantir o controle de qualidade. Objetivo: Relatar a utilização de um Sistema de Gerenciamento de CME (SGCME) de parâmetros de limpeza, esterilizaçáo e rastreabilidade do IC no ICESP. Resultado: No ICESP a rastreabilidade ocorre nas diversas áreas do CME. Expurgo: IC é conferido, separado e identificado. A caixa é rastreada pelo código de barras e o SGCME é alimentado com número da termolavadora, e os respectivos parâmetros do processo de limpeza. Preparo e esterilizaçăo: $\mathrm{O}$ instrumental é separado, seco, submetido à inspeçáo visual com lente e lubrificado. $\mathrm{O}$ SGCME éalimentado com os parâmetros utilizados na escolha do processo de esterilizaçāo. Rastreabilidade: Realizada, peça a peça, via leitura ótica dos códigos DataMatrix para conferencia do quantitativo e emissão da relação dos IC que compóe a caixa. A seguir, o IC é acondicionado, colocado indicador de processo, filtro, lacre e identificado com data de produçáo, validade e colaborador do CME. Arsenal: As caixas são armazenadas em local pré-determinado, conforme etiqueta de identificação. A distribuição das caixas é realizada mediante programação cirúrgica. A montagem do carro é realizada com a leitura dos códigos de barra das caixas, relacionando o paciente, horário da cirurgia, sala de operação e colaborador do CME. Conclusão: SGCME controla e padroniza todos os processos, monitora parâmetros físicos, químicos e biológicos, emite relatórios diários e mensais da produtividade, identifica instrumental extraviado ou enviado para conserto e programa manutençôes preventivas do IC.

\section{Metástase Cutânea de Tumor Renal: Relato de Caso}

Vieira SA, Bernardes IC, Castelo Branco MD de 0, Melo FM de, Souza MF de, Ataíde S de A Universidade Federal da Parába, Hospital Napoleão Laureano

Introduçáo: $\mathrm{O}$ carcinoma renal atinge principalmente indivíduos entre 50 a 70 anos de idade, com predomínio nas mulheres $(1,5: 1)$, representando $3 \%$ das neoplasias. Possuem maior risco de desenvolver a doença indivíduos expostos ao asbesto e cádmio, fumantes e portadores de doença renal cística em diálise. O carcinoma renal possui disseminação metastática precoce e curta sobrevida. Aproximadamente $25 \%$ dos pacientes possuem metástase no momento do diagnóstico e $10 \%$ apresentam sintomas clássicos (dor lombar, hematúria e massa palpável no flanco). Em ordem decrescente de freqüência, as metástases localizam-se em: pulmóes, linfonodos, ossos, fígado, sistema nervoso central e pele. A metástase cutânea é rara. Objetivo: Relatar e discutir um caso de metástase cutânea de carcinoma renal. Metodologia: Realizou-se revisão do prontuário e acompanhamento da paciente. Resultados: C.S, 32 anos, feminino, branca, solteira, natural e procedente de Cajazeiras (PB). Paciente com história prévia de nefrectomia direita há três anos. Devido a um carcinoma renal, procurou o ambulatório do Hospital Napoleáo Laureano apresentando tumoraçáo na regiāo frontal esquerda com abaulamento do couro cabeludo há três meses. Paciente relatou cefaleia intensa, vômitos e tontura. $\mathrm{Na}$ análise histopatológica, foi diagnosticado carcinoma renal de células claras metastático. A Tomografia Computadorizada de crânio mostrou massa expansiva com extensão à calota craniana e partes moles. Conclusáo: Apesar da raridade de metástase cutânea de tumor renal, salienta-se a importância de sua suspeiçấo frente a nódulos de aparecimento repentino em indivíduos com história prévia de tumor renal. Devemos sempre realizar biópsia da lesáo excisada, pois a metástase cutânea está entre os diagnósticos diferenciais do granuloma piogênico. 
Complicaçôes do Tratamento Cirúrgico de Tumor de Células Gigantes ao Redor do Joelho

\section{Furtado EF, Brito LL, Cavalcante $\mathrm{H}$ de C, Figueiredo DN de, Chacon Neto $\mathrm{O}$ de $\mathrm{H}$ Centro Paraibano de Ciências Ortopédicas. João Pessoa (PB), Brasil}

Introduçáo: O Tumor de Células Gigantes (TCG) é um tumor benigno agressivo. É comum localização junto à articulação, sendo cerca de $50 \%$ no joelho. A ressecçáo apresenta chance de cura, mas é um desafio remover todo tumor e preservar/restaurar a funçáo. Reconstrói-se com substituiçấo por um homoenxerto ou autoenxerto, artrodese, metilmetacrilato ou endoprótese não convencional (EPNC). Objetivo: Demonstrar o resultado do tratamento do TCG em joelho com reconstrução. Metodologia: Entre maio de 2003 e abril de 2009, foram ressecados 23 TCG do joelho - 14 no fêmur e 9 na tíbia. Idade média de 29,4 anos. Segmento pós-operatório de 4 a 71 meses. Todos estadiados e submetidos à biópsia percutânea no pré-operatório. Realizada ressecção ampla do tumor em seis casos: cinco reconstruídos com EPNC e um com artrodese. Ressecçăo intralesional em 17 casos, seguido de reconstrução com enxerto ósseo autólogo em cinco; com cimento acrílico (polimetilmetacrilato) em quatro, com enxerto ósseo autólogo e cimento acrílico em oito. Resultados: Constatado 26,06\% de complicações - infecção em dois casos, ambos com EPNC e duas fraturas de fêmur distal. Um caso evoluiu com metástase pulmonar. Recidiva em um caso com EPNC, submetida à revisão. Sem evidência de necrose do enxerto, soltura do cimento ortopédico, osteólise ou colapso articular. Conclusáo: Constatado elevado índice de complicaçôes, apenas um tratamento radical; não houve sequelas nos demais. As complicaçôes ocorreram nos pacientes com EPNC. Não houve complicaçấo no uso de enxerto. A associaçăo de enxerto e cimento não levou à necrose. A reconstrução biológica permanece ideal para preenchimento de lesōes resultantes de ressecção de TCG.

61

\section{Carcinossarcoma de Vesícula Biliar: Relato de um} Caso

Lima IAB de, Leite CRC, Melo FST, Paiva ARQ de, Gama R de C, Oliveira LS Hospital Napoleão Laureano, Universidade Federal da Paraíba

Carcinossarcoma de vesícula biliar é um tumor raro, caracterizado pela presença de células malignas epiteliais e mesenquimatosas. A maioria dos pacientes são mulheres, na sexta ou sétima décadas de vida. A apresentação clínica, geralmente é de dor abdominal, associada à massa em hipocôndrio direito, acompanhada ou não de icterícia. O diagnóstico é feito por exame histológico e imunoistoquímico, mas os achados clínicos e exames de imagem podem auxiliar no diagnóstico diferencial. $\mathrm{O}$ tratamento é cirúrgico, complementado, se necessário, por métodos adjuvantes. Apesar da conduta agressiva, o prognóstico é desfavorável, sendo a sobrevida média de oito meses. Este trabalho objetiva relatar um caso de carcinossarcoma de vesícula biliar, atendido no Hospital Napoleão Laureano (HNL). Realizado através de coleta de dados a partir da avaliaçáo clínica e revisão do prontuário de uma paciente de 63 anos, feminino, parda, natural e procedente de Alagoa Grande (PB), que deu entrada no ambulatório de cirurgia abdominal do HNL, após colecistectomia em outro serviço, cujo laudo histopatológico (LHP) evidenciou sarcoma fusocelular de vesícula biliar. $\mathrm{O}$ exame físico não apresentava alteração. Foi solicitado imunoistoquímica que mostrou positividade para pancitoqueratina, antígeno epitelial de membrana e vimentina, sendo os aspectos histológicos compatíveis com carcinossarcoma. Paciente foi encaminhada à oncologia clínica, a fim de complementar tratamento. Apesar de bastante raro, o carcinossarcoma deve ser considerado no diagnóstico diferencial dos tumores de vesícula biliar, dado reforçado pela necessidade de imunoistoquímica no diagnóstico. Sua confirmação faz-se necessária ainda, visto que ele pode ser curado, quando o tumor está restrito ao órgão.
Invaginação Jejunojejunal da Alça Aferente por Sonda Nasoenteral Pós-Gastrectomia Subtotal

\section{Oliveira LS, Ferreira Filho A de A, Carvalho Filho CR, Paiva ARQ, Lima IAB de, Mello FST} Hospital Napoleão Laureano, Universidade Federal da Paraíba

O termo invaginação foi descrito por Hunter através peristaltismo anterógrado ou retrógado, levando à invaginação do segmento distal. A invaginação intestinal é a principal causa de obstruçáo intestinal em menores de cinco anos, predominando no sexo masculino. Após estabelecida a invaginaçáo, pode ocorrer resolução espontânea ou obstrução, com sofrimento vascular. Todo cirurgiāo deve estar familiarizado com a sintomatologia que é rica, mas pouco específica. $\mathrm{O}$ diagnóstico de certeza é cirúrgico. $\mathrm{O}$ prognóstico depende do diagnóstico precoce. $\mathrm{O}$ índice de mortalidade chega a 50\% após 48 horas de evolução. O objetivo deste trabalho é relatar um caso de invaginação intestinal jejunojejunal diagnosticado no $3^{\circ} \mathrm{DPO}$ de gastrectomia subtotal, realizada no Hospital Universitário Lauro Wanderley/ UFPB. Utilizou-se avaliação clínica e resgate do prontuário de uma paciente de 58 anos, procedente de Souza (PB) submetida à gastrectomia subtotal por adenocarcinoma de antrogástrico. Evoluiu no $3^{\circ} \mathrm{DPO}$ com náuseas, vômitos, distensão abdominal, sinais de irritação peritoneal, sendo indicada relaparotomia, evidenciando invaginação intestinal jejunojejunal a $30 \mathrm{~cm}$ do ângulo de Treitz, tendo como cabeça da intuscepçáo a oliva da sonda de Dobb-Hoff. A invaginação intestinal foi tratada conservadoramente através de redução manual do segmento distal intussusceptum do proximal intussuscepiens e preservação do segmento envolvido. A paciente evoluiu bem, recebendo alta no $10^{\circ} \mathrm{DPO}$. A intussuscepção intestinal é rara em adultos, porém deve ser sempre lembrada nos pacientes submetidos à cirurgia abdominal que evoluem com quadro de obstrução. Na literatura não foi encontrado o cateter de Dobb-Hoff na fisiopatologia de intussuscepção de alça eferente em adultos.

62

\section{Tumor Carcinoide Gástrico: Relato de um Caso}

\section{Lima IAB de, Leite CRC, Mello FST, Paiva ARQ de, Furtado RMP de M, Araújo K de E} Hospital Napoleão Laureano, Universidade Federal da Paraíba

Os tumores carcinoides são neoplasias do sistema neuroendócrino difuso. A incidência desses tumores oscila em 0,7 casos por 100.000 habitantes, sendo os sistemas gastrintestinal e respiratório os sítios mais frequentes. A elevação urinária do ácido 5-hidroxiindolacético constitui método útil para o diagnóstico, entretanto a hipótese pré-operatória de tumor carcinoide é rara, sendo o diagnóstico, geralmente, feito por análise histológica. $\mathrm{O}$ tratamento se faz com cirurgia, complementada por métodos adjuvantes, se necessário. Este trabalho objetiva relatar um caso de tumor carcinoide gástrico, atendido no Hospital Napoleão Laureano (HNL), realizado através de coleta de dados, a partir da avaliação clínica e revisão do prontuário de um paciente de 43 anos, masculino, pardo, natural e procedente de Santa Rita (PB), que procurou o ambulatório de cirurgia abdominal do HNL, com queixa de disfagia e azia, há dois anos. Negava perda ponderal. Endoscopia digestiva alta mostrou mucosa da transição esofagogástrica com lesão elevada, endurecida, medindo cerca de $1 \mathrm{~cm}$, de contornos regulares, localizada em parede posterior, imediatamente abaixo da linha Z. Realizou biópsia, cujo laudo histopatológico (LHP) revelou adenocarcinoma de média diferenciação. Ultrassonografia de abdômen total e radiografia de tórax não revelaram alteraçáo. Paciente foi submetido à gastrectomia total com linfadenectomia e reconstrução em Y de Roux, evoluindo sem complicaçôes. LHP evidenciou tumor carcinoide na mucosa da transição gastroesofágica. Apesar de apresentar crescimento lento, o tumor carcinoide é considerado neoplasia maligna com poder de metastatização, principalmente para fígado. Por isso, não se deve ter atitude indolente na assistência terapêutica, visto que isso altera consideravelmente a sobrevida. 
Carcinoma Indiferenciado da Tireoide: Relato de Caso

Araújo K E de, Benévolo A M de, Castelo Branco MD de 0, Loureiro AD Hospital Napoleão Laureano, Universidade Federal da Paraíba

Carcinoma indiferenciado da tireoide (CIT) é uma das neoplasias mais agressivas, que perdeu a maioria das características originais do tecido. Prevalece em mulheres, entre sexta e sétima décadas de vida. Sua incidência é de um a dois para 1.000.000 habitantes. Crescimento tumoral rápido é presságio de mortalidade precoce, a menos que se institua tratamento combinado agressivo. A melhor conduta é cirurgia agressiva associada com quimioterápicos e radioterapia. Relatar caso de CIT. História clínica e cirúrgica de portadora de CIT. Coleta de dados a partir da avaliaçáo clínica e revisão de prontuário. J.F.M., feminino, 72 anos, natural de João Pessoa (PB). Deu entrada no Serviço de Cirurgia de Cabeça e Pescoço no Hospital Napoleão Laureano (HNL) com queixa de nódulo tireoideano e lesấo em couro cabeludo. Foi realizada ultrassonografia da tireoide com dopplerfluxometria mostrando tireoide aumentada de volume, com nódulo misto no lobo direito (D); tomografia computadorizada da tireoide mostrou processo expansivo sólido no lobo D; citologia aspirativa da tireoide, com quadro citológico de padrão folicular com atipias. Foi realizada tireoidectomia total. Anatomopatológico diagnosticou CIT. Biópsia cutânea da lesão em couro cabeludo mostrou sarcoma fusocelular. Paciente encaminhada à oncologia clínica e radioterapia. O CIT é um dos grandes desafios a serem suplantados por cirurgiōes de cabeça e pescoço. Os protocolos já estudados não foram capazes de oferecer cura aos nossos pacientes, mas puderam prolongar suas sobrevidas. Embora não tenhamos protocolo ideal, as evidências sugerem que o tratamento (combinando cirurgia, radioterapia e quimioterapia) traz melhores resultados. Pacientes com tumor ressecável podem se beneficiar desse tratamento.

\section{Osteossarcoma de Maxila em Adolescente}

Bernardes IC, Oliveira LS, Lima IAB de, Arruda RF, Vieira SA, Fernandes KL Universidade Federal da Parába, Hospital Napoleão Laureano

Osteossarcoma é o tumor ósseo mais comum na infância e adolescência, acometendo, predominantemente, ossos longos. Ocasionalmente, pode acometer ossos faciais, representando menos de $10 \%$ dos osteossarcomas diagnosticados e se comportando com agressividade. Osteossarcoma de maxila, frequentemente, envolve adultos entre 30 e 40 anos. A ressecção cirúrgica com margens livres, associada à quimioterapia adjuvante, é o principal fator prognóstico. O objetivo desse trabalho é relatar um caso de osteossarcoma de maxila diagnosticado e tratado no Setor de Cirurgia de Cabeça e Pescoço do Hospital Napoleão Laureano (HNL), a partir da história clínica e cirúrgica da paciente acometida, além da revisâo retrospectiva de seu prontuário. Paciente feminino de 17 anos, natural e procedente de Joáo Pessoa (PB). Encaminhada, pela Oncologia Pediátrica, por apresentar destruição óssea da face e consequente distorção da anatomia bucomaxilofacial. Realizada quimioterapia neoadjuvante, com resposta parcial, para posterior realização de maxilectomia total acrescida de etmoidectomia e reconstruçáo com retalhos miocutâneos. Anatomopatológico evidenciou osteossarcoma de maxila. Encontra-se em tratamento quimioterápico adjuvante. $\mathrm{O}$ osteossarcoma de maxila, além de ser incomum na prática da Cirurgia de Cabeça e Pescoço, quando comparado ao osteossarcoma de mandíbula, é uma neoplasia rara em paciente jovem. Seu conhecimento se faz necessário uma vez que, nâo diagnosticado, a invasáo tumoral compromete a anatomia e fisiologia do local. A agressividade desse tumor faz com que a maioria dos pacientes se apresente em fase avançada da doença, porém uma intervenção cirúrgica eficiente associada à terapia adjuvante propicia maior sobrevida.
Laringectomia Total Alargada à Pele: Tumor de Comissura Anterior

Oliveira LS, Fernandes KL, Lucena VL de, Loureiro AD, Castelo Branco MD de, Araújo KE de Hospital Napoleão Laureano, Universidade Federal da Parába

O câncer de laringe é um dos mais comuns na regiáo da cabeça e pescoço, representando aproximadamente $25 \%$ dos tumores malignos dessa regiáo. As pregas vocais são os sítios mais acometidos. $\mathrm{O}$ tabagismo e o etilismo são os fatores predisponentes mais importantes. O objetivo deste trabalho é relatar e discutir um caso de paciente com tumor de comissura anterior extravasado para pele, atendido no Setor de Cirurgia de Cabeça e Pescoço do Hospital Napoleáo Laureano (HNL). Utilizaram-se as avaliaçóes clínica, cirúrgica e análise de prontuário de um paciente de 61 anos, agricultor, tabagista e alcoolista. Queixava-se de rouquidáo há um ano e dispneia de repouso. Ao exame, apresentava tumoraçáo em regiáo cervical anterior, ulcerada de aproximadamente $5 \mathrm{~cm}$, móvel à deglutição. A videolaringoscopia evidenciou lesão ulcerada e infiltrativa de comissura anterior, com paralisia de prega vocal esquerda. Evoluiu com insuficiência respiratória, sendo indicado traqueostomia urgente. A tomografia computadorizada de laringe mostrava lesão expansiva sólida comprometendo laringe, espaço pré-epiglótico, cartilagem tireoide com extravasamento para pele, com linfadenomegalia cervical bilateral. $\mathrm{O}$ paciente foi submetido a uma laringectomia total alargada à pele mais esvaziamento cervical radical bilateral tipo III e reconstrução com retalho fasciocutâneo deltopeitoral. $\mathrm{O}$ anatomopatológico evidenciou carcinoma escamocelular pouco diferenciado. O paciente evoluiu com fístula salivar de pequeno débito, tratado conservadoramente. Após a alta, foi encaminhado à radioterapia adjuvante; encontra-se sem evidência de doença locorregional, alimentando-se via oral e em treinamento da voz esofágica. A laringectomia total associada à radioterapia ainda é o tratamento de escolha para os tumores avançados de laringe, estadiamentos III e IV.

66

\section{Aquisição da Voz Esofágica: Relato de Caso}

\section{Araúio KE de, Marchi MVD, Castelo Branco MD de 0, Loureiro AD, Lucena VL de, Oliveira LS} Hospital Napoleão Laureano, Universidade Federal da Paraíba

Laringectomia total é o procedimento cirúrgico através do qual toda laringe é removida. Segundo Komalski et al. (2000), é indicada em tumores extensos, impossibilitados de terapias conservadoras. A reabilitação fonoaudiológica dos pacientes é uma das contribuiçôes mais valiosas. Existem várias maneiras com as quais os indivíduos laringectomizados podem compensar perda da voz laríngea. Consiste na introdução do ar no esôfago e, quando da percepçáo da sua entrada, é retornada e modificada pelos articuladores e ressoadores, produzindo a voz (Fúria et al., 2000). Relatar caso de laringectomia total com posterior aquisiçăo da voz esofágica. História clínica e cirúrgica de laringectomizada total. Coleta de dados a partir da avaliaçáo clínica e revisão de prontuário. M.L.S.S., feminino, 56 anos, natural de Tenório (PB). Deu entrada no Serviço de Cirurgia de Cabeça e Pescoço no Hospital Napoleáo Laureano (HNL) com queixa de disfonia e nódulos no pescoço há quatro meses. À videolaringoscopia, visualiza-se lesão nodular comprometendo face laríngea da epiglote. Realizada traqueostomia de urgência e laringoscopia com exérese de papiloma. Biópsia revelou carcinoma indiferenciado. Paciente encaminhada à radioterapia. Realizou-se laringectomia total com esvaziamento cervical. Anatomopatológico evidenciou carcinoma epidermoide pouco diferenciado, ulcerado da laringe; comprometendo regiáo supraglótica, infra-hióidea e glótica à direita. Paciente encaminhada à fonoaudiologia, fazendo uso da voz esofágica. Sem recidivas há dois anos. $\mathrm{O}$ impacto decorrente da laringectomia total é a perda da voz laríngea. Torna-se imprescindível atuação fonoaudiológica na reabilitaçăo, com finalidade de recuperaçáo da fonação, implicando na reintegraçáo social do paciente, após frustraçáo com a mutilação física e perda da voz. 


\section{Schwanoma de Nervo Facial}

Bernardes IC, Oliveira LS, Lima IAB de, Castelo Branco MD, Loureiro AD, Macena FCS Universidade Federal da Paraíba, Hospital Napoleão Laureano

Schwanomas são tumores benignos da bainha de nervos cranianos ou espinhais. Em geral, são solitários, ovoides ou fusiformes, bem encapsulados, de crescimento lento e com baixo potencial de malignização, o que possibilita cura completa por abordagem cirúrgica. Raramente podem se apresentar como tumores malignos; quando desta natureza, localizam-se preferencialmente na regiáo da cabeça e pescoço. O objetivo desse estudo é relatar caso de schwanoma de nervo facial diagnosticado e tratado no Setor de Cirurgia de Cabeça e Pescoço do Hospital Napoleão Laureano (HNL), a partir da história clínica e cirúrgica do paciente, além da revisão retrospectiva de seu prontuário. Paciente masculino, 59 anos, casado, agricultor, natural e procedente de Sapé (PB). Queixava-se de tumoração em regiâo parótida direita. Ao exame físico, lesão nodular, superficial, de crescimento lento, consistência elástica e sem linfonodos palpáveis tanto homolateral quanto contralateralmente. À punção aspirativa com agulha fina, quadro histológico compatível com lesão cística. Exame radiológico de tórax e da mastoide direita normais. Realizou-se parotidectomia superficial direita. Anatomopatológico evidenciou tumoraçáo nodular compatível com schwanoma, tecido parotídeo adjacente sem particularidade e margens cirúrgicas livres de neoplasia. Paciente segue em acompanhamento ambulatorial, sem evidência de doença. Esse tipo de neoplasia é de extrema importância na prática dos Cirurgióes de Cabeça e Pescoço, uma vez que é necessário o diagnóstico diferencial com outras neoplasias que podem afetar a glândula parótida, tal como o adenoma pleomórfico. Isso porque essa glândula tem como relação intrínseca ramos ou o próprio tronco do nervo facial, sétimo par de nervos cranianos.

\section{Exenteração Pélvica Total no Tratamento de Resgate da Neoplasia de Reto Localmente Avançada}

Lima IAB de, Leite CRC, Mello FST, Paiva ARQ de, Vieira AS Hospital Napoleão Laureano, Universidade Federal da Paraíba

A exenteração pélvica total (EPT) é um procedimento cirúrgico que consiste na remoçáo de órgãos pélvicos, incluindo útero, ovários, vagina, ureteres distais, bexiga e retossigmoide; tem sido indicada para o tratamento de neoplasias pélvicas avançadas primárias, persistentes ou recorrentes. Este trabalho objetiva avaliar os resultados da EPT como resgate no tratamento da neoplasia de reto localmente avançada, com invasão da bexiga urinária. Foram realizadas duas EPT no Hospital Napoleăo Laureano (HNL). A avaliação pré-operatória da extensão da doença incluiu dosagem de CEA, cistoscopia, colonoscopia, tomografia abdominopélvica e radiografia torácica. Todos os doentes apresentavam confirmaçăo histológica da neoplasia. As cirurgias foram realizadas por cirurgióes oncológicos e urologistas. Foram avaliados: tipo de cirurgia, indicação, complicaçōes perioperatórias, duração de internamento, complicaçóes pós-operatórias precoces e tardias, morbimortalidade, intervalo livre de doença, recorrência e sobrevida. Os dois pacientes eram homens com idade média de 68,6 anos. Nenhum paciente tinha invasão óssea do sacro. Todos os pacientes foram submetidos à ressecçấo com margens livres (R0). A morbidade foi de $33 \%$ e não houve mortalidade operatória. A média de permanência hospitalar foi de dez dias. Todos os pacientes estão vivos, sem evidência de doença locorregional ou a distância. A sobrevida média é de 25 meses. A EPT constitui uma alternativa curativa nos pacientes com tumores retais recorrentes com invasão da bexiga. Enfatiza o impacto da ressecção completa na sobrevida dos pacientes, que apresentam pouca resposta a outros métodos. A EPT determinou melhoria da qualidade de vida desses doentes que, frequentemente, apresentam sintomas debilitantes e de difícil manejo clínico.
Schwannoma Gástrico: Relato de Caso

\section{Oliveira LS, Paiva ARQ, Leite CRC, Lima IAB de, Mello FST, Bernardes IC} Universidade Federal da Paraíba, Hospital Napoleão Laureano

Os tumores neurogênicos correspondem a $10 \%$ dos tumores gástricos benignos. Entre esses tumores, há os schwannomas que são neoplasias que se desenvolvem nas células de Schwann, na bainha dos nervos periféricos. A presença de schwannomas no trato gastrointestinal é incomum, sendo no estômago observado a maior frequência dessas neoplasias. O objetivo deste trabalho é relatar um caso raro de schwannoma do estômago. Utilizouse avaliação clínica e resgate do prontuário de uma paciente de 36 anos, branca, portadora de lesão nodular na submucosa da parede posterior do corpo gástrico, de crescimento progressivo. Foi submetida, no Serviço de Cirurgia Abdominal do Hospital de Câncer Napoleấo Laureano (HNL), em João Pessoa $(\mathrm{PB})$, à gastrectomia parcial com uso de grampeador linear $55 \mathrm{~mm}$, evoluindo sem intercorrências. O perfil imunoistoquímico da peça operatória revelou positividade difusa para Proteína S-100 e presença do Antígeno KI-67 em menos de 1\% das células, quadro associado a schwannoma do estômago. O schwannoma gástrico é tumor neurogênico, originado das células de Schwann, pouco frequente, que se comporta de modo invariavelmente benigno, sem as incertezas prognósticas de um tumor estromal gastrintestinal (GIST). Deve fazer parte do diagnóstico diferencial das lesóes submucosas do estômago. A ressecçấo cirúrgica com margens de segurança é habitualmente curativa.

\section{Sarcoma Pleomórfico}

Bernardes IC, Oliveira LS, Castelo Branco MD de 0, Loureiro AD, Leite CRC, Mello FST Universidade Federal da Parába, Hospital Napoleão Laureano

Os sarcomas constituem um grupo heterogêneo de tumores com diversos tipos histológicos que compartilham uma origem mesodérmica comum com pequeno componente ectodérmico. São mais comuns em adultos acima de 50 anos, não há relação uniforme de distribuição por sexo e podem ser evidenciados em qualquer parte do corpo. Os pacientes apresentam-se como uma massa extensa, indolor e assintomática no sítio anatômico do tumor. $\mathrm{O}$ prognóstico é determinado por parâmetros clínicos e características patológicas, não representando o subtipo histológico, fator prognóstico consistente. O objetivo desse estudo é relatar um caso de sarcoma pleomórfico grau III histológico diagnosticado e tratado no Setor de Cirurgia Abdominal do Hospital Napoleão Laureano (HNL). Utilizou-se avaliaçáo clínica e cirúrgica, além de resgate do prontuário de uma paciente de 63 anos, casada, natural e procedente de Mamanguape (PB). Queixava-se de dor em hipocôndrio esquerdo e epigástrio há alguns meses. À tomografia computadorizada de abdômen total, detectou-se lesão expansiva com medidas estimadas de 17 x $14,7 \times 11 \mathrm{~cm}$, situada em regiấo epigástrica, mesogástrica e hipocôndrio esquerdo. Alfa fetoproteína normal. Realizada laparotomia exploradora, pancreatectomia corpocaudal, esplenectomia, gastrectomia segmentar e colectomia parcial. Anatomopatológico evidenciou neoplasia maligna anaplásica com extensas áreas de necrose. Perfil imunoistoquímico solicitado para definir histogênese, concluiu sarcoma pleomórfico grau III histológico infiltrativo em tecido fibroconjuntivo. Paciente segue em acompanhamento ambulatorial. Sarcomas são tumores de alto grau de malignidade, devendo-se, portanto, ressaltar a atuação do Cirurgiāo Oncológico, visando ao estabelecimento de diagnóstico e tratamento precoces com consequente melhora do prognóstico dos pacientes. 


\section{Laringectomia com Miotomia do Cricofaríngeo: Impacto na Reabilitação Vocal}

Castelo Branco MD de 0, Loureiro AD, Araújo KE de, Oliveira LS, Fernandes KL, Lucena VL Universidade Federal Parába, Hospital Universitário Lauro Wanderley

Introduçáo: $\mathrm{O}$ câncer de laringe (CL) constitui $1 \%$ a $2 \%$ dos tumores malignos no mundo, sendo dividido em glótico, supraglótico e subglótico. Associa-se ao tabagismo e ao alcoolismo. A laringectomia total (LT) é indicada no tratamento de tumores que comprometem os três níveis da laringe. O principal impacto desse procedimento é perda da voz laríngea, tornando fundamental reabilitação vocal dos pacientes. A LT com miotomia do cricofaríngeo (MC) consiste em cortar fibras do músculo cricofaríngeo ou do esfíncter esofagiano superior. Isso melhora o fluxo faringoesofágico, facilitando aquisição da voz esofágica. Objetivo: Relatar um caso de LT com MC e impacto dessa técnica na reabilitação vocal. Metodologia: Avaliação cirúrgica e fonoaudiológica de paciente atendido no setor de Cirurgia de Cabeça e Pescoço (CCP) do Hospital Napoleão Laureano (HNL). Resultados: Paciente masculino, 49 anos. Procurou CCP queixando-se de disfonia progressiva há um ano. A videolaringoscopia apresentou paralisia de prega vocal esquerda e ulceração em hemilaringe esquerda. Ausência de linfadenopatia cervical. Tomografia computadorizada evidenciou lesão em hemilaringe esquerda. Anatomopatológico evidenciou Carcinoma Espinocelular (CEC). Submeteu-se à LT com MC, esvaziamento cervical bilateral níveis II a V e reconstruçáo com retalho deltopeitoral. Anatomopatológico evidenciou CEC glótico, comprometendo laringe, faringe, tecidos moles, além de tecido adiposo e muscular, sendo indicada radioterapia complementar. Paciente foi encaminhado ao Setor de Fonoaudiologia do HNL. Evolui satisfatoriamente em relaçáa à aquisiçấo da voz esofágica e está em bom estado geral. Conclusáo: LT com MC melhora a qualidade de vida de pessoas submetidas à LT, por possibilitar reabilitaçáo vocal satisfatória e precoce, auxiliando na reintegraçáo social.

73

\section{Exenteração Pélvica: Relato de Caso e Papel na Sobrevida}

\section{Castelo Branco MD de 0, Loureiro AD, Serrano NNM, Carlos GMB, Gondim A, Guerra K de C} Hospital Napoleão Laureano, Universidade Federal da Paraíba

Exenteração pélvica (EP) é procedimento cirúrgico radical que consiste na remoção de órgãos pélvicos. Classifica-se em anterior, quando se retiram órgãos genitais femininos (OGFs), ureteres distais e bexiga; em posterior, quando há retirada dos OGFs e retossigmoide; e, em total, com ressecção de todas essas estruturas. Inicialmente, EP era considerada cirurgia paliativa, porém, o refinamento das técnicas de reconstruçáo elevou a sua utilização, apesar da morbidade, oferecendo cura a pessoas que, sem cirurgia radical, sucumbiriam à doença. Este trabalho objetiva relatar um caso de EP, atendido no Hospital Napoleão Laureano (HNL), na Paraíba, através de avaliação clínica e análise do prontuário de uma paciente de 32 anos, com queixas de dor e massa em ânus. Ao exame, observou-se volumosa tumoraçáo anorretal. Submeteu-se à retossigmoidectomia. Anatomopatológico confirmou CEC invasor. Realizou radioterapia e quimioterapia complementar. Após cinco anos, evoluiu com lesão ulcerada em vulva, uretra e vagina. Solicitou-se parecer da oncologia clínica e radioterapia. Como tratamentos radioterápicos e quimioterápicos náo foram indicados, foi proposto realizaçáo de EP. Paciente foi orientada sobre caráter agressivo da cirurgia. Após consentimento, realizou-se EP, com confecção de colostomia em alça com anastomose uretero-colônica. Anatomopatológico demonstrou CEC em ureter e vulva, com margens comprometidas em ambas as peças. Apêndice cecal, bexiga e borda da colostomia não apresentaram malignidade, sendo indicada quimioterapia. Atualmente, encontra-se em acompanhamento ambulatorial, em bom estado geral. Apesar da elevada taxa de morbidade inerente à cirurgia radical, EP é importante no arsenal da cirurgia oncológica, oferecendo potencial para sobrevivência a pacientes antes considerados terminais. Risco de Neoplasias Neuroendocrinas em
Pacientes Obesos

Cruz RP, Faria-Corrêa BM de, Sampaio F, Gomes MWS, Mottin C Centro de Cirurgia Endócrino Metabólica da PUCRS, Porto Alegre (RS), Brasil

Introduçáo: $\mathrm{O}$ tumor Carcinoide (TC) é raro, acomete- $0,025 \%$ da população. Objetivos: Descrever série de casos de obesos atendidos na PUCRS, para cirurgia bariátrica $(\mathrm{CB})$, com TC gastrointestinal e diagnóstico endoscópico pré-operatório. Material e Métodos: Descriçáo de série de casos a partir de dados clínicos, laboratoriais e cirúrgicos. Resultados: CASO 1: Homem, 55 anos, IMC $=50,4 \mathrm{~kg} / \mathrm{m}^{2}$, plano de CB. Apresentava apneia do sono, colelitíase e esteatose hepática. Em EDA pré-operatória, removeu-se pólipo carcinoide duodenal. Gastrina: 14,1pg/ml. Negava sintomas GI. Realizou-se gastrectomia por Sleeve e colecistectomia, encontrando-se quatro nódulos hepáticos, sendo realizada hepatectomia parcial. Patologia e imunoistoquímica (IQ) revelaram adenoma biliar. Após seis meses, exames não evidenciaram neoplasia; assintomático, IMC $=35 \mathrm{~kg} / \mathrm{m}^{2}$. CASO 2: Mulher, 41 anos, IMC $=52 \mathrm{~kg} / \mathrm{m}^{2}$ submetida à $\mathrm{CB}$. História: enterorragia e menorragia. $\mathrm{EDA}$ pré-operatória: tumor carcinoide de $6 \mathrm{~cm}$ na grande curvatura gástrica. Negava rash facial, diarreia ou dispneia. Tomografia e colonoscopia normais; ultrassonografia transvaginal: mioma $1,3 \times 1,7 \mathrm{~cm}$ na parede posterior uterina. Realizada gastrectomia subtotal, histerectomia e biópsia hepática; sem lesōes. IMC $=28,47 \mathrm{~kg} / \mathrm{m}^{2}$, após sete meses. CASO 3: Mulher, 32 anos, $\mathrm{IMC}=44,4 \mathrm{~kg} / \mathrm{m}^{2}$, com síndrome de Turner e hipotireoidismo submetida à CB. Negava sintomas GI. EDA pré-operatória: múltiplos pólipos no corpo gástrico. Biópsia: TC. IQ: tumor bem-diferenciado neuroendócrino. Gastrina: 798pg/ml. Realizadas gastrectomia subtotal e linfadenectomia regional. Patologia: dois TC envolvendo mucosa e submucosa. Linfonodos livres. Após oito meses, $\mathrm{IMC}=30,3 \mathrm{~kg} / \mathrm{m}^{2}$, gastrina $<10$, assintomática. Conclusão: Atualmente nota-se aumento da incidência de TC gástrico. Mudanças na dieta, obesidade, exposição ambiental e maior expectativa de vida podem estar associadas. Endoscopia auxilia o diagnóstico. OTC parece ser mais frequente em pacientes obesos.

Laparoscopic Wedge Gastrectomy and Sentinel Lymph Node Mapping for Early Gastric Cancer Following On-Table Endoscopic Submucosal Injection of Patent Blue

\section{Magnus AM, Gomes BFC, Corezola KL, Boff MF, Cirne-Lima FK, Moreira LF} Southern Surgical Oncology Group -Porto Alegre, Brazil

Background: Sentinel node mapping by trans-serosal injection of patent blue during laparoscopic gastrectomy, either with or without preoperatively lymphoscintigraphy has been recently used as the standard procedure in early gastric cancer in order to selectively assess node status. Case Report: A 64-yearold male patient with an early gastric tumour was submitted to laparoscopic gastrectomy in May 2007. Sentinel lymph node mapping was carried out exclusively by on-table endoscopic injection of patent-blue dye. Four lymph nodes, at coeliac trunk (sentinel), left gastric, splenic and common hepatic artery, were found, respectively. Wedge resection of the stomach was performed at the end of the procedure. Recovery was uneventful and the patient was discharged on the 3rd post-operative day. Histology revealed a 20x25mm Type 0 -IIc lesion in the lesser curvature posterior wall of the gastric body (below the cardia) confined into the sm1 submucosal layer with clear margins and diagnosed as a poorly differentiated adenocarcinoma of the stomach. All four dissected lymph nodes clearly stained by patent blue were microscopically and immunohistochemically negative for tumour involvement as assessed by AE1 and $\mathrm{AE} 3$ anti-keratin antibodies. The patient is still asymptomatic and diseasefree 27 months following operation. Discussion: On-table endoscopic injection of patent blue is easy and feasible for helping selective lymph nodes dissection and precludes preoperatively lymphoscintigraphy. Moreover, immunohistochemical assessment may help to better define node involvement at a molecular level. This has been the attempted procedure at our Institution. 
Melanoma Anal: Relato de Quatro Casos

\section{Ribeiro PHA, Lima KS, Siqueira RR, Santos FA, Barral CM, Wainstein AJA BIOCANCER, ONCAD - Belo Horizonte (MG), Brasil}

Introduçáo: $\mathrm{O}$ Melanoma anal tem prognóstico reservado devido ao diagnóstico tardio e metástase precoce. $\mathrm{O}$ tratamento permanece controverso. Objetivo: Relatamos quatro casos da doença e mostramos a importância do diagnóstico precoce e a aplicabilidade da biópsia de linfonodo sentinela. Caso 1: Homem, 54 anos, relatou nódulo na regiâo perianal, tratado como hemorroida. Realizou ressecção da lesão e anatomopatológico revelou melanoma maligno invasor anal, com imunoistoquímica positiva para proteína S100 e negativa para anticorpo HMB45. Biópsia do linfonodo sentinela demonstrou melanoma seguido por linfadenectomia inguinal esquerda. Após dois anos, retornou com nódulo doloroso na região perianal e três nódulos no couro cabeludo. Caso 2: Homem, 81 anos, com melanoma anal avançado e obstrutivo submetido à amputaçấo abdominoperineal. Realizou quimioterapia e radioterapia com regressão total da linfadenomegalia inguinal. Evoluiu com metástase hepática, pulmonar. Caso 3: Mulher, 47 anos, dois anos com nódulo perianal e sangramento. Ressecado com ampliação da margem. Diagnosticou-se nódulo inguinal e realizou linfadenectomia à esquerda. Diagnóstico de melanoma anal estádio III. Recebeu, quatro meses após, seis doses da vacina polipeptídica e dez meses depois Doppler revelou nódulo abaixo da cicatriz da linfadenectomia, não metastático. Ultrassonografia abdominal normal e inguinal com linfadenomegalia, negativa para metástases. Caso 4: Mulher, 40 anos, apresenta nódulo perianal pigmentado, tratado como mamilo hemorroidário trombosado. Diagnóstico de melanoma maligno. Em pesquisa de linfonodo sentinela com captação na regiâo inguinal esquerda. Todos negativos para metástases. Paciente em acompanhamento, sem recidivas. Conclusão: $\mathrm{O}$ diagnóstico precoce associado à biópsia de linfonodo sentinela pode melhorar o estadiamento e a terapêutica.

77 Melanoma Metastático: Análise de Pacientes com
Longa Sobrevida

Ribeiro PHA, Lima KS, Chaves G, Santos FA, Drummond-Lage AP, Wainstein AJA BIOCANCER, ONCAD - Belo Horizonte (MG), Brasil

Introduçáo: $\mathrm{O}$ melanoma apresenta baixa incidência, representando $4 \%$ dos tipos de câncer de pele e possui elevada letalidade. No melanoma metastático a sobrevida média é de seis a nove meses após o diagnóstico e a sobrevida em cinco anos é de aproximadamente $5 \%$. Objetivo: Objetivamos analisar pacientes com melanoma metastático que evoluem com longa sobrevida. Metodologia: Analisados 317 pacientes com melanoma, foram identificados 18 com melanoma metastático e sobrevida consideravelmente maior. Resultados: Foram submetidos à ressecção da lesão primária. A idade variou de 30 a 73 anos. O Breslow variou de $0,64 \mathrm{~mm}$ a 7,2 $\mathrm{mm}$. Os linfonodos (estádio IV) foram os órgãos mais acometidos pela metástase. Em cinco pacientes, foi diagnosticada metástase pulmonar; em dois, metástase óssea. Com longa sobrevida, apenas um paciente teve comprometimento hepático. Foram cinco pacientes com comprometimento de mais de um órgão. Dos pacientes, cinco foram tratados com quimioterapia; três com terapia associada (QT e/ou vacina e/ou radioterapia e/ou INF). A sobrevida variou de 18 meses a 154 meses, média de 38 meses. Apenas um apresenta-se sem evidências de recorrência da patologia até o momento. Conclusóes: O melanoma é agressivo, mas pode se alcançar sobrevida de longa duraçáo mesmo no estádio IV. A sobrevida média é de seis a nove meses. Apesar disso, pode-se obter sobrevida de longa duração por meio da associação de terapias locais, sistêmicas e imunomoduladoras.

\section{Pancreatectomia Caudal com Esplenectomia Videolaparoscópica no Tratamento de Metástase de Tumor Ovariano Relato de Caso}

\section{Ribeiro PHA, Kansaon MJM, Santos FA, Oliveira BR, Wainstein AJA} Hospital Lifecenter - Belo Horizonte (MG), Brasil

Introduçáo: A ressecção laparoscópica do pâncreas permanece incomum. São vantagens do procedimento as pequenas incisôes, redução da dor pós-operatória, retorno precoce às atividades cotidianas e diminuição das complicaçóes relacionadas à ferida. Caso: Relatamos o caso de paciente do sexo feminino, 73 anos, submetida em agosto de 2004 à pan-histerectomia com esvaziamento linfonodal e omentectomia devido à adenocarcinoma de ovário. Realizada quimioterapia adjuvante. Em 2008, apresentou quadro de emagrecimento e, à ultrassonografia, nota-se lesão em baço. A tomografia multislice do abdômen mostrou lesão expansiva no pedículo esplênico, envolvendo seu parênquima e cauda pancreática. Foi indicada laparoscopia prévia à laparotomia para estadiamento, já que, em casos de recidiva de câncer de ovário, frequentemente, a doença é multicêntrica, contraindicando qualquer procedimento não paliativo. Em março de 2008, submetida à laparoscopia que, ao contrário do esperado, mostrou lesão metastática única acometendo o baço e cauda do pâncreas. A paciente foi então submetida à pancreatectomia caudal com esplenectomia vídeolaparoscópica em monobloco sem intercorrências, recebendo alta hospitalar no quinto dia de internação. Resultado anatomopatológico e imunoistoquímico de metástase de adenocarcinoma de ovário em baço. Está em controle ambulatorial periódico, evoluindo com ganho de peso, sem evidências de recidiva. Conclusóes: A videolaparoscopia permitiu realização de cirurgia oncológica radical, com boa evolução pós-operatória e retorno rápido às suas atividades habituais.

\section{Amputação de Membros: Fatores Envolvidos nesta Evolução Desfavorável do Carcinoma Escamocelular da Pele}

Sampaio DV, Oliveira TA, Oliveira BRR, Castro EV, Carvalho RA, Wainstein AJA BIOCANCER, ONCAD, Hospital Alberto Cavalcanti - FHEMIG - Belo Horizonte (MG),

Brasil

Introduçáo: $\mathrm{O}$ carcinoma escamocelular (CEC) da pele é um tumor maligno de células queratinizadas da epiderme, sendo a segunda causa de morte por câncer de pele. A maioria dos casos ocorre em áreas do corpo expostas à luz solar. A história da doença é variável, podendo se apresentar como uma lesão de crescimento lento e sem metástases ou como um tumor rapidamente crescente, com metástases diversas. Materiais e Métodos: Foi realizada uma análise, através de entrevistas e revisão de prontuários de uma série de casos que culminaram em amputaçấo de membros, devido à invasão local da doença. Foram avaliados os fatores demográficos, histológicos, institucionais e pessoais que contribuíram para esse desfecho desfavorável. Resultados: Foram estudados os pacientes com diagnóstico histológico de CEC de pele que tiveram membros amputados em nossa instituiçâo entre 2005 e 2008, por invasão do tumor. A idade média de diagnóstico foi de 63 anos; apenas $37,5 \%$ dos pacientes (três pacientes) tinham exposiçấo abusiva e contínua aos raios solares, mas seis, dos oito pacientes $(75 \%)$, tinham outros fatores de risco para CEC de pele. Sete, dos oitos pacientes, foram diagnosticados quando o tumor já era maior que $2 \mathrm{~cm}$, e foi necessário um período grande de tempo (6,7 anos em média) entre o aparecimento da lesăo inicial e o diagnóstico histopatológico correto do tumor localmente avançado. Conclusão: Os pacientes com lesóes avançadas (maiores que 2 $\mathrm{cm}$ ) săo de alto risco para invasáo locorregional e metástases, e devem ser tratados de maneira agressiva e precisa para se evitar futuras amputaçôes. 
Notes Transvaginal Diagnostic Staging:

Preliminary Clinical Application

Biazatti G, Corona JS, Sousa MM, Cosentino CC, Fernandes SC, Zorrón R Departamento de Cirurgia/ HCTCO/UNIFESO - Teresópolis (RJ), Brasil

Laparoscopy is now a reliable method for staging gastrointestinal cancer, orienting the therapy, and avoiding unnecessary laparotomy. Natural orifice transluminal endoscopic surgery (NOTES) is an emerging concept with potential advantages for patient recovery. Laparoscopy is now a reliable method for staging gastrointestinal cancer, orienting the therapy, and avoiding unnecessary laparotomy. Natural orifice transluminal endoscopic surgery (NOTES) is an emerging concept with potential advantages for patient recovery. The first case of clinical diagnostic application of transvaginal NOTES for diagnostic cancer staging is presented. Informed consent and Institutional Commission approval were obtained for transvaginal clinical trials. On February 28, 2007, a patient with elective surgical indication for diagnostic cancer staging was submitted to transvaginal NOTES procedure, and intra- and postoperative parameters were documented. In a 50-yearold female patient presenting with ascitis, diffuse abdominal pain, and weight loss for 2 months, diagnosis of peritoneal carcinomatosis was suspected, which was also found when a CT scan was performed. Transvaginal NOTES was used for diagnostic staging of the patient, using a colonoscope introduced into the abdomen through a small incision in the vagina. Biopsies of liver, diaphragm, ovaries, and peritoneum were successfully performed. Operative time was $105 \mathrm{~min}$, vaginal access and closure was obtained in $15 \mathrm{~min}$. Abdominal inventory was reliable, and all 16 biopsies taken were positive for ovarian adenocarcinoma. The patient was dismissed 48 hours after the procedure without complications. Recent literature and experience of the study group suggest possibilities for preliminary clinical applications by transvaginal natural orifice surgery for diagnostic purposes.

81

\section{Cirurgia em Pacientes sob Cuidados Paliativos: Experiência do Instituto Nacional de Câncer (INCA)}

Barros A, Reis J, Maciel A, Resende F, Santos L, Prisco E Serviço de Cuidados Paliativos/Instituto Nacional de Câncer (INCA)/MS - Rio de Janeiro (R)),

Objetivos: Cuidado paliativo em câncer é definido como terapias que visam à melhora da qualidade de vida dos pacientes com doença avançada, e a cirurgia paliativa é uma importante parte desse cuidado oncológico multidisciplinar. Relatamos os resultados do manejo cirúrgico dos pacientes em cuidados paliativos do Instituto Nacional de Câncer (INCA). Material e método: Estudo retrospectivo dos pacientes com câncer em cuidados paliativos submetidos à intervenção cirúrgica no INCA, no período de janeiro/2006 a junho/2008. Resultados: Cento e trinta e seis pacientes foram submetidos a 174 procedimentos cirúrgicos; 88 (64,7\%) eram do sexo masculino e $48(35,3 \%)$ do sexo feminino, com uma média de idade de 51,5 (30-83) anos. A maioria dos pacientes eram portadores de tumores de cabeça e pescoço, representando $61,8 \%$ dos casos. Cento e trinta e dois pacientes apresentavam doença locorregional avançada (97\%) e em 55 (40,5\%) foram observadas metástases a distância, sendo o pulmão o sítio mais frequente $(11 \%)$. A disfagia (parcial ou total) foi a principal causa das indicaçóes cirúrgicas (51\%), seguida da obstrução das vias aéreas (42\%), obstruçâo intestinal (12\%) e sangramentos (8\%). A cirurgia mais realizada foi a traqueostomia, em 61 pacientes $(44,8 \%)$, representando $35 \%$ das cirurgias realizadas. A sobrevida média global foi de 90,1 (4-1.045) dias. Conclusão: A paliação cirúrgica é um componente importante do aparato multidisciplinar no tratamento de pacientes com câncer terminal. Estudos com maiores casuísticas e a avaliação da experiência de outros Centros são necessários para um melhor julgamento do momento ideal da indicação desse tratamento paliativo.
Diagnostic Laparoscopy for Stenosing Carcinoid of the Small Bowel with Long Follow-up After Right Hepatectomy

Corona JS, Biazatti G, Leite JA, Zorrón R Department of Surgery, University Hospital Teresópolis - HCTCO/UNIFESO

Objectives: The ileal carcinoid tumor, for showing symptoms of mild and low degree of clinical suspicion, is a difficult desease to diagnose by imaging methods available. Diagnostic laparoscopy shown as one of the alternatives for diagnosis when the complementary methods and image are flawed. In case of carcinoid syndrome, hepatectomy is the best therapy for liver tumors. The report aims to suggest laparoscopy as a complimentary method of investigation in small bowel obstruction due to intestinal tumors and as improvement in the techniques of anatomical approach, the use of LigaSure for division of hepatic parenchyma with only vein ligacion caliber, shortening the operative time and blood loss. Methods: Case report of a patient 61 years, who presented obstructive symptoms for three months and who underwent laparoscopic diagnosis after carrying abdominal CT and MRI, colonoscopy and small bowel transit, with normal results. Made after two years, six right hepatectomy for tumor metastases. Results: During laparoscopy was the diagnosis of stenosing carcinoid of the ileum, wich was confirmed by biopsy freezing. After two years of development, the liver metastases were treated by right hepatectomy anatomical. Conclusion: The laparoscopy proved to be a good option for a diagnosis of difficult clinical approach to clarify the origin of the obstruction. In additional terms, anatomical resection of liver parenchyma with ligation of vessels and prior use of LigaSure directly into de parenchyma, are factors that facilitate the implamentation of the procedure without transfusions.

Cirurgia minimamente Invasiva no Tratamento de Tumores Carcinoides do Trato Gastrointestinal Proximal: Relato de Dois Casos

Kansaon MJM, Reis P, Santos FAV, Oliveira BRR, Parreiras FC, Wainstein AJA Hospital Mater Dei - ONCCAD - Belo Horizonte (MG), Brasil

Introduçáo: $\mathrm{O}$ tumor carcinoide é afecção pouco frequente e, no trato gastrointestinal, o estômago e o duodeno são raramente acometidos, sendo a incidência observada de $2,8 \%$ e 2,9\%, respectivamente. Seu tratamento é essencialmente cirúrgico e, recentemente, a videolaparoscopia tem sido utilizada como forma de acesso operatório. Relato de casos: Relatamos dois casos de pacientes com tumores carcinoides submetidos a tratamento cirúrgico videolaparoscópico. CASO 1: Paciente do sexo masculino, 72 anos, apresentando dor epigástrica vaga. Submetido à endoscopia digestiva alta com percepçáo de atrofia da mucosa do antro e inúmeros pólipos em fundo gástrico, cuja histologia foi compatível com tumor carcinoide. Foi submetido à gastrectomia subtotal distal videolaparoscópica. Evoluiu sem intercorrências no pós-operatório. CASO 2: Paciente do sexo feminino, 67 anos, apresentando dispepsia de início recente; à endoscopia digestiva alta, notava-se lesấo polipoide na primeira porção duodenal, diâmetro aproximado de $1,0 \mathrm{~cm}$, compatível com o diagnóstico de tumor carcinoide à histologia. Foi submetida à ressecção videolaparoscópica do tumor com auxílio peroperatório da endoscopia. Apresentou evolução pós-operatória sem intercorrências. Conclusão: $\mathrm{O}$ tumor carcinoide é afecçáo pouco frequente e o seu tratamento é cirúrgico. A videolaparoscopia acrescenta os benefícios de menor intensidade de dor pós-operatória e retorno precoce às atividades cotidianas sem, no entanto, comprometer a radicalidade oncológica. 
Tratamento Videolaparoscópico de Volumoso

GIST Gástrico: Relato de Caso

Santos FAV, Kansaon MJM, Parreiras FC, Wainstein AJA ONCCAD - Hospital das Clínicas da UFMG - Belo Horizonte (MG), Brasil

Introduçáo: Os tumores estromais gastrointestinais (GIST) foram recentemente descritos com entidade clínica isolada. $\mathrm{O}$ tratamento cirúrgico é a única forma para obtenção da cura da doença, apesar dos avanços alcançados com a quimioterapia. O estômago é o órgáo mais frequentemente acometido no trato gastrointestinal. Relato de caso: Relatamos o caso de paciente oligosintomática, submetida à endoscopia digestiva alta, na qual se notou lesão subepitelial em curvatura maior gástrica. À endossonografia, confirmou-se o achado de tumor da muscular própria do estômago com características compatíveis com GIST. À tomografia abdominal, percebia-se tumor gástrico de crescimento exofítico, em curvatura maior e com diâmetro aproximado de $5,0 \mathrm{~cm}$. Foi submetida à gastrectomia em cunha, videoassistida e grampeamento gástrico a céu aberto. A evolução pós-operatória transcorreu sem intercorrências. O GIST constitui entidade clínica muito particular, com terapia molecular específica estabelecida, mas tem na cirurgia a única forma de obtençáo de cura. Conclusáo: A ressecçáo videolaparoscópica do tumor estromal é cada vez mais utilizada e deve-se tomar cuidado especial para não ocorrer ruptura da lesão com consequente piora do prognóstico. Neste caso, ressecamos volumoso GIST preservando os princípios oncológicos e proporcionando ao paciente os benefícios de acesso cirúrgico menos invasivo.

\section{Estudos sobre Implantação dos Diagnósticos de Enfermagem em Pacientes Portadores de Neoplasias Encefálicas}

Souza AS, Valadares GV

Escola de Enfermagem Anna Nery (EEAN/UFRJ)

Trata-se do Estado da Arte sobre Implantação dos Diagnósticos de Enfermagem em Pacientes Portadores de Neoplasias Encefálicas e um recorte de Projeto de Pesquisa de Mestrado inserido no Núcleo de Pesquisa de Fundamentos do Cuidado de Enfermagem da EEAN/UFRJ. Os tumores do sistema nervoso central são raros e dividem-se de acordo com sua localizaçáo, tipo celular, histologia ou faixa etária que eles acometem. Os pacientes acometidos por um tumor do $\mathrm{SNC}$ apresentam sinais e sintomas relacionados a três categorias gerais: déficit neurológico progressivo, cefaleias ou convulsōes. A sistematização da assistência de enfermagem está associada à organização da assistência direta ao paciente/cliente clínico ou cirúrgico, hospitalizado e tem como ferramenta (majoritariamente) o Processo de Enfermagem. A fase do diagnóstico de enfermagem envolve análise, interpretaçáo dos dados coletados, avaliação crítica e tomada de decisão. Neste cenário, buscou-se levantar um perfil da produção científica sobre o tema nos últimos dez anos em bases de dados indexadas como: Lilacs, SciELO, Medline e livros. As produçóes científicas encontradas referem-se a produçóes aos relatos de experiência de construçáo de um instrumento para registro da sistematização da assistência de enfermagem; identificação de diagnóstico de enfermagem em uma população/área específica; validação da nomenclatura diagnóstica de enfermagem e implantaçáo dos diagnósticos de enfermagem em nível hospitalar/rede básica de saúde. Este levantamento mostrou que não há estudos relacionados aos diagnósticos de enfermagem em neurocirurgia oncológica. Portanto, a produçáo de enfermagem sobre o tema é insipiente, evidenciando a necessidade de maior investigação nesse campo de atuação.
Análise Histológica de Pele Normal na Localização de Melanomas de Origem Incerta em Amostras mal Identificadas

Sampaio DV, Lima KS, Barral C, Santos FA, Salome MO, Wainstein AJA BIOCANCER - Nuclear Med Center - HC/UFMG - Laboratório Salomé - Belo Horizonte

(MG), Brasil

Introduçáo: $\mathrm{O}$ exame anatomopatológico é fundamental para o diagnóstico de neoplasias. É necessário que coleta, armazenamento e identificação sejam feitos adequadamente. Se realizado de forma imprópria, a capacidade diagnóstica do exame histológico fica comprometida. Objetivo: Nosso objetivo foi descrever a metodologia utilizada para identificar cinco amostras de lesōes de pele ressecadas e colocadas no mesmo frasco, cujo diagnóstico foi de melanoma com margens comprometidas. Metodologia: Um paciente do sexo masculino, 43 anos, portador de múltiplas lesóes pigmentadas, submetido a cinco ressecçōes de pele nas regióes: temporal direita, nasal, inguinal esquerda, axilares direita e esquerda, que foram armazenadas no mesmo frasco. $\mathrm{Na}$ análise histopatológica, foi identificado em uma das amostras melanoma com 0,4 mm de extensão, Breslow $0,2 \mathrm{~mm}$. Clark nível I, fase de crescimento radial, retração cicatricial e margens comprometidas. $\mathrm{O}$ sítio de origem da lesão em questão não estava identificado entre as cinco peças. Nova revisão foi realizada à procura de aspectos histológicos que pudessem esclarecer o local do melanoma. Estudando folículos pilosos, camadas celulares, glândulas cutâneas, tipos celulares e arquitetura histológica, o patologista presumiu que o melanoma originara-se da região inguinal. Como tal análise não é procedimento padrão, foi realizada ampliação das cinco ressecçóes prévias. Conclusáo: A previsăo do patologista mostrou-se verdadeira, pois o espécime inguinal revelou células do melanoma no tecido cicatricial. Os aspectos histológicos de diversas partes corporais podem ser úteis na localização de tumores com sítio de origem incerta. Entretanto, ressaltamos a importância da identificação das amostras coletadas no diagnóstico anatomopatológico das lesōes.

86

\section{Cirurgia de Kaminishi para Tratamento da Neoplasia Maligna Obstrutiva e Irressecável do Antro Gástrico}

Vieira SA, Lima IAB de, Paiva ARQ de, Vieira DA, Leite CRC, Mello FST Universidade Federal da Parába, Hospital Napoleão Laureano

Introduçáo: $\mathrm{O}$ câncer gástrico é uma importante causa de mortalidade no mundo, representando a terceira neoplasia maligna mais frequente e predominando no sexo masculino (2:1), com pico entre 55 e 70 anos. Interaçóes entre o $H$. pylori e fatores ambientais, tais como tabagismo e hábitos alimentares, parecem estar relacionados à maior ocorrência de lesôes pré-neoplásicas e câncer gástrico. Altas taxas de mortalidade devemse tanto à sua elevada prevalência, quanto à dificuldade em estabelecer um diagnóstico precoce, o que implica baixos índices de tratamento curativo. Objetivo: Avaliar os resultados da gastrojejunostomia particionada (Cirurgia de Kaminishi) para tratamento paliativo da obstrução gástrica distal em paciente com carcinoma gástrico irressecável. Metodologia: Foram realizadas três gastrojejunostomias pela técnica de Kaminishi, no Serviço de Cirurgia Abdominal do Hospital de Câncer Napoleão Laureano, em João Pessoa (PB). Todos os pacientes apresentavam neoplasia de estômago distal com obstrução pilórica e sinais de irressecabilidade. A cirurgia consistiu de partiçáo do estômago, com grampeador linear $55 \mathrm{~mm}$, mantendo-se um túnel de aproximadamente $3 \mathrm{~cm}$ de diâmetro na pequena curvatura gástrica, seguida de anastomose gastrojejunal na parte proximal do estômago, com sutura contínua de poliglactina 910 3-0. Resultados: Todos os pacientes evoluíram com drenagem satisfatória da gastrojejunostomia, recebendo alta com alimentação oral normal. Não houve morbi-mortalidade pósoperatória. Conclusão: A cirurgia de Kaminishi melhora o esvaziamento gástrico, evita o sangramento contínuo e a obstrução precoce do estoma pelo crescimento da neoplasia, podendo ser usada com segurança nos casos de neoplasia de estômago com obstrução e irressecabilidade para melhoria da qualidade de vida do paciente. 
Pelveglossomandibulectomia: Relato de Caso

Castelo Branco MD de O, Loureiro AD, Araújo KE de, Oliveira LS, Fernandes KL, Lucena VL de Universidade Federal da Paraíba, Hospital Universitário Lauro Wanderley

Introduçáo: O câncer de cavidade oral (CO) representa 3\% a 5\% das neoplasias malignas no mundo, sendo carcinoma epidermoide o mais comum. Apresenta comportamento agressivo, com metastatizaçáo cervical precoce e frequente. Cirurgia e radioterapia são, isolada ou associadamente, terapias mais aplicáveis ao câncer de CO. A escolha do tratamento depende da localizaçăo e do estadiamento clínico. Como o diagnóstico, geralmente, é tardio, há necessidade de tratamentos mais agressivos, na tentativa de curar a doença mais avançada. Nesse sentido, pode-se optar pela cirurgia de pelveglossomandibulectomia. Nesta, retira-se importantes estruturas da $\mathrm{CO}$, podendo levar a alteraçóes na mastigaçáo, deglutiçáo e fala; porém incorporação de técnicas de reconstrução imediata permitiu largas ressecçôes com melhor recuperaçáo dos pacientes. Contudo, deformidades ainda sáo grandes e o prognóstico, muitas vezes, reservado. Objetivos: Relatar um caso de pelveglossomandibulectomia e seu impacto na qualidade de vida. Metodologia: Avaliação clínica, cirúrgica e fonoaudiológica de paciente atendido no Hospital Napoleão Laureano, João Pessoa (PB). Resultados: Paciente, 60 anos, apresentando lesão ulcerada infiltrando rebordo gengival inferior, com estádio clínico T4N0M0. Submeteu-se à pelveglossomandibulectomia, com esvaziamento cervical radical tipo III à esquerda e reconstrução com retalho miocutâneo. Anatomopatológico evidenciou carcinoma epidermoide moderadamente diferenciado. Foi encaminhada à Fonoudiologia do HNL, evoluindo satisfatoriamente em relação à alteração na fala. Atualmente, está em bom estado geral. Conclusão: O tratamento do câncer de CO é complexo e de caráter multidisciplinar. Dessa forma, cirurgióes oncológicos, ao realizarem a pelveglossomandibulectomia, devem almejar náo só a cura, mas minimizar efeitos decorrentes desta, com a finalidade de aperfeiçoar o uso das estruturas remanescentes, promovendo o bem estar dos pacientes. 89

\section{Papel da Experiência e Especialidade do Cirurgião no Prognóstico de Pacientes com Câncer: Revisão Bibliográfica}

\section{Andrade MR de, Castelo Branco MDO, Loureiro AD, Oliveira LS, Bernardes IC, Loureiro AD} Universidade Federal da Paraiba

Introduçáo: A cirurgia constitui uma das principais modalidades do tratamento de pacientes com câncer. A atuaçấo do cirurgião pode alterar a evoluçáo dos casos, a mortalidade pós-operatória, intervalo livre de doença, taxa de recidiva e qualidade de sobrevida. Nesse sentido, os fatores relacionados ao cirurgiáo, especialidade e experiência estáo implicados nos resultados cirúrgicos adequados e no prognóstico. Objetivo: Estudar a influência da especialidade e da experiência do cirurgiáo no prognóstico dos pacientes. Metodologia: Revisão de literatura na base de dados Pubmed em língua inglesa no período de janeiro de 2000 a agosto de 2009, utilizando os seguintes termos surgeon, oncology e prognosis. Foram excluídos os artigos que tratavam exclusivamente de condutas cirúrgicas ou que náo analisavam o papel do cirurgiấo nos resultados cirúrgicos. Resultados: Foram selecionados nove artigos, sendo um deles uma revisão bibliográfica. Dos artigos relacionados, quatro avaliaram a especialidade do cirurgiấo e quatro avaliaram a experiência. Dos que avaliaram a especialidade do cirurgiáo, somente um dos artigos concluiu que a especialidade do cirurgião alterou o prognóstico dos pacientes $(\mathrm{p} \leq 0,005)$; em relação à experiência do cirurgião, todos relacionaram algum benefício quando o cirurgiâo tinha maior experiência, mas somente um deles com dados consistentes foi relacionado a um menor risco de recidiva $(\mathrm{p}=0,0053)$. Conclusão: São necessários mais estudos com medidas de resultado mais consistentes para se chegar a uma conclusão definitiva sobre a importância do cirurgiáo no prognóstico dos pacientes.
Tumor Carcinoide de Intestino Delgado Associado à Síndrome Carcinoide e Carcinomatose Peritoneal: Relato de Caso

Vieira L, Oliveira AF, Fraga JBP, Costa RRL, Nascimento ACR Associação Feminina de Prevenção e Combate ao Câncer (ASCOMCER) Juiz de Fora (MG), Brasil

Tumores carcinoides (TCD) são neoplasias neuroendócrinas raras (38,5:1.000.000), derivadas das células enterocromafins e caracterizadas pela produçáo de neuropeptídios. Cursam com clínica inespecífica (dor abdominal, diarreia, perda ponderal e vômitos) e, em menos de $10 \%$ dos casos, com síndrome carcinoide (fogachos, rubor facial, diarreia, sibilos e repercussōes cardíacas). A localizaçáo mais comum é o trato gastrointestinal (55\%), seguido pelo pulmão $(30,1 \%)$ e pâncreas $(2,3 \%)$. Entre os TCD gastrintestinais, o intestino delgado é o local mais frequente $(44,7 \%)$, seguido pelo reto $(19,6 \%)$ e apêndice (16,7\%). O padrão ouro para diagnóstico é a dosagem urinária de ácido 5-hidroxiindolacético e/ou cromogramina sérica associada à cintilografia com auxílio de Octreoscan ${ }^{\circ}$, e confirmado pela anatomopatologia e imunoistoquímica. O tratamento curativo é eminentemente cirúrgico, com área de ressecçáo dependente do tamanho e localizaçăo tumoral. Outras opçóes seriam citorreduçâo na doença disseminada, quimioterapia em tumores indiferenciados, e radioterapia nas metástases ósseas. Já a síndrome carcinoide responde bem ao octreotida subcutâneo. Os autores relatam o caso de um paciente masculino, 57 anos, com queixas de flush súbito, diarreia e sibilos que, após vários atendimentos médicos, detectou-se múltiplos nódulos hepáticos através de ultrassonografia abdominal. Referenciado ao serviço de oncologia, lançou-se a hipótese diagnóstica de tumor neuroendócrino. Pela tomografia abdominal, evidenciou-se lesão mesentérica de íleo terminal e nódulos hepáticos bilaterais. O Ecocardiograma revelou cardiopatia fibrótica em válvula tricúspide e exames bioquímicos indicaram elevaçâo das taxas de ácido 5-hidroxiindolacético e cromogramina A sérica, decidindo-se, então, pela abordagem cirúrgica (enterectomia, colecistectomia e omentectomia). Atualmente, encaminhado para quimioembolização das lesôes hepáticas. 90

\section{Liga Acadêmica Norte-Mineira de Cirurgia (LANMC): Relato de Experiência em Cirurgia Oncológica}

Gomes CHR, Freitas MOS de, Guimarães PMS, Carneiro JA, Silva JA da, Poswar F de 0 Hospital Universitário Clemente de Faria, Universidade Estadual de Montes Claros (UNIMONTES), Montes claros (MG), Brasil

Introduçáa: As Ligas Acadêmicas vêm sendo reconhecidas como importante instrumento de ensino, pesquisa e extensáo dentro de uma especialidade médica. Tềm como princípio a divulgaçâo da especialidade, o resgate da relação médico-paciente, bem como o incentivo ao ensino da Medicina através de atividades práticas. Objetivos: Relatar a experiência em cirurgias oncológicas da LAMNC, criada em março de 2008, em estágios realizados em hospital especializado na cidade de Montes Claros (MG). Método: Análise de relatórios finais dos acadêmicos participantes, nos quais constavam o número de procedimentos acompanhados, o número de trabalhos científicos realizados e de apresentações de temas relacionados em eventos. Resultados: Durante seis meses de estágio, 13 acadêmicos participaram de 234 cirurgias oncológicas das mais diversas, com média de 18 cirurgias por acadêmico. Em relaçáo à participaçáo em trabalhos científicos, foram contabilizados 13 no total, tendo estes sido apresentados em quatro congressos de especialidades. Conclusáo: A LANMC constitui-se em valioso instrumento para a comunidade acadêmica, agregando interesses e promovendo a expansão do ensino da cirurgia e um maior contato com a especialidade, fundamental para a formação do médico, desde a graduação. 
Prognóstico de Pacientes com Câncer de Laringe Avançado, Submetidos ao Tratamento Baseado em Radioterapia/Quimioterapia ou em Cirurgia

Barbieri F, Santos CR, Mano JB, Boldrini DJ, Barreto JV, Carvalho AL Hospital de Câncer de Barretos - Barretos (SP), Brasil

Objetivos: Avaliar o prognóstico de pacientes com câncer de laringe avançado (estádios T3 e T4) tratados com terapia baseada em cirurgia ou radioterapia/quimioterapia (protocolo de preservaçáo de órgáo). Material e Método: Estudo de coorte, retrospectivo, do Hospital de Câncer de Barretos, no período de 2005 a 2007. Para análise dos dados, foi utilizada a estatística descritiva, sendo a análise de sobrevida global e livre de doenças calculadas pelo método Kaplan-Meier. Para comparação das curvas, o método log-rank. Foram considerados significativos valores de $\mathrm{p}<0,05$. Resultados: Cinquenta e oito pacientes foram estadiados como T3 (48,3\%) e 62 como T4a (51,7\%); $40 \%$ dos pacientes possuíam metástase cervical. O tratamento baseado em radioterapia foi realizado em 90 pacientes $(75,0 \%)$, sendo $88,9 \%$ com quimioterapia concomitante; e, baseado em cirurgia, 30 pacientes $(25,0 \%)$, sendo $86,7 \%$ com radioterapia pós-operatória. Recidiva local ocorreu em 26,7\% dos casos. A sobrevida global em três anos foi de $48,9 \%$. Considerando-se o tratamento realizado, os pacientes submetidos ao tratamento cirúrgico apresentaram uma sobrevida em três anos de $49,5 \% \mathrm{e}$ os pacientes submetidos à radioterapia $48,8 \%(\mathrm{p}=0,640)$. As lesôes glóticas apresentaram melhor prognóstico com $73,1 \%$, comparado com os tumores supraglóticos, 46,0\%, e os transglóticos, 32,7\% ( $\mathrm{p}=0,019)$. Os tumores classificados como T3 tiveram uma melhor sobrevida $(\mathrm{p}=0,007)$. Conclusáo: $\mathrm{O}$ tratamento baseado em radioterapia (associado com quimioterapia) apresentou o mesmo prognóstico dos casos submetidos à cirurgia (associado à radioterapia pós-operatória). $\mathrm{O}$ tratamento nâo cirúrgico, nos casos avançados de laringe, deve ser considerado como possibilidade de preservação de órgão sem comprometer o prognóstico do paciente.

\section{Adrenalectomia Videoendoscópica Retroperitoneal}

Carrizo FD, Cunha Neto SH, Gurgel CNR, Kanaan E, Meira DA, Zorron R Hospital Universitário Clementino Fraga Filho - Rio de Janeiro (RJ), Brasil

Objetivo: A adrenalectomia laparoscópica vem se tornando uma alternativa para a doença adrenal benigna, substituindo a cirurgia convencional na maioria das indicaçóes. A técnica de adrenalectomia videoendoscópica retroperitoneal (AVR) emerge como alternativa na abordagem dessas lesóes comparada ao acesso convencional e laparoscópico transabdominal (LTA). O estudo prospectivo avalia uma série de 25 pacientes submetidos à AVR e LTA, comparando suas características e resultados. Métodos: Em quatro anos, 13 pacientes foram submetidos à AVR (Grupo I) e 12 à técnica LTA (Grupo II) em nossa instituiçáo e prospectivamente documentados. Os dados avaliados foram tempo operatório, tipo e tamanho das lesóes, estimativa de sangramento, transfusão, tempo de internação e complicaçóes intra e pós-operatórias. Resultados: As indicaçōes mais frequentes foram adenoma não funcionante e feocromocitoma. Não houve diferença significativa entre o diâmetro dos tumores ressecados pelas diferentes vias. Houve conversão para cirurgia aberta em um paciente de cada grupo. O tempo operatório foi mais longo para o Grupo II, comparado à via AVR. A estimativa de sangramento operatório foi maior para o Grupo II, comparado ao Grupo I. Não houve complicaçōes pós-operatórias. O tempo de internaçẫo foi em média menor para o Grupo I. Conclusôes: Os resultados iniciais favorecem o reconhecimento da exequibilidade e segurança do método de AVR para doenças adrenais. A técnica pode ser indicada em tumores adrenais de até $8 \mathrm{~cm}$ de diâmetro, quando o espaço de manipulação ainda é adequado. A técnica poderá ser o procedimento de escolha para a maioria das lesóes adrenais, em especial, em pacientes obesos, com cirurgia abdominal prévia.
O Gene P53 e os Mecanismos de Reparo do DNA na Gênese Oncológica

Leite DRC, Sousa TTS, Leite RRC, Sousa TTS, Barbosa IJS Universidade Federal da Paraíba, João Pessoa (PB), Brasil

Introdução: A carcinogênese é um processo de vários estágios, envolvendo a ativaçáo de proto-oncogenes como o RAS e a inativaçáo de genes supressores de tumor como os membros da família do gene $\mathrm{p} 53$. Objetivos: Abordar o gene p53 e os mecanismos de reparo do DNA na implicação da gênese oncológica. Material e Métodos: Revisão de literatura baseada nos artigos publicados nos últimos cinco anos na base de dados Pubmed, nos quais se relacionam as falhas nos mecanismos de reparo do DNA e o gene p53 no contexto da oncogênese. Resultados: $\mathrm{O}$ espectro mutacional do gene $\mathrm{p} 53$ difere entre os cânceres de cólon, pulmão, esôfago, mama, fígado, cérebro e de tecidos reticuloendoteliais e hematopoiéticos. É sabido que o p 53 é essencial na proteção das células da radiação UVB induzida por dano ao DNA, promovendo parada do ciclo celular ou apoptose. Alteraçôes no gene $\mathrm{p} 53$ induzem a expressão de diversos outros genes, incluindo o homólogo humano do gene MDM2 e do p21WAF1/CIP1. Alteraçóes na expressão do p53/MDM-2/p21 são características comuns de CECs orais. As mutaçôes do gene $\mathrm{p} 53$ são raramente encontradas em NPC, mas a expressão da proteína $\mathrm{p} 53$, bem como da oncoproteína $\mathrm{Bcl}-2$, foi relatada em uma alta porcentagem de casos, em associaçáo com EBV. Conclusáo: A patologia molecular é um tema de destaque para a carcinogênese, tendo os membros da família do gene p53 um papel fundamental na determinaçáo da resposta ao tratamento do câncer.

\section{Ganglioneuroma Retroperitoneal em Criança de 4 Anos}

Oliveira AF, Vieira L, Ghetti TM, Moreira AA, Fraga JBP Instituto Oncológico do Hospital 9 de Julho - Juiz de Fora (MG), Brasil

Os ganglioneuromas (GNs) pertencem ao grupo de tumores neuroblásticos, os quais se originam da crista neural e são compostos de células ganglionares maduras e células de Schwann. Esses tumores são benignos e raramente são sintomáticos não apresentando características de tumores secretores de hormônios como as catecolaminas, assim, quando esses apresentam sintomas, provavelmente se dá por compressão de estruturas adjacentes e, nesses casos, a sintomatologia mais comum é a epigastralgia e dor abdominal. São bem delimitados, podendo ser parcialmente envoltos por tecido fibroso, embora, muitas vezes, apresentem uma verdadeira cápsula fibrótica, que facilita na sua identificação e diferenciaçấo. Podem ocorrer em todas as faixas etárias, sendo mais comumente encontrados em crianças e adultos jovens ( $40-60 \%)$, sendo 7 anos a média de idade de ocorrência. Apresentam maior predileçáo pelo sexo feminino na proporçấo de 3:1. Neste relato, uma criança de 4 anos, sexo feminino, com quadro gripal, após exame físico, foi detectado tumor abdominal extenso em flanco esquerdo. Foram solicitadas ultrassonografia e tomografia computadorizada abdominais, que evidenciaram volumosa massa sólida, que se estendia desde a transiçãa toracoabdominal ao hipocôndrio esquerdo. Decidiu-se pela exérese do tumor, que se localizava em andar superior de abdômen, com invasão de diafragma esquerdo, para tanto, ressecou-se diafragma e glândula suprarrenal esquerdos, além do baço, cauda de pâncreas e junção esôfago gástrica, em monobloco, medindo $16,0 \times 12,0 \times 7,0 \mathrm{~cm}$. Reconstruiu-se o diafragma com malha de polipropileno monofilamentar-márlex (Tela de Marlex) mais drenagem intercostal fechada de tórax em selo d'água. Ao exame anatomopatológico, chegou-se ao diagnóstico de GN. 


\section{Tumor Desmoide: Revisão Literária e Relato de Caso}

\section{Oliveira AF, Vieira L, Almeida EP, Santos LC, Nascimento ACR} Hospital Monte Sinai - Juiz de Fora (MG), Brasil

Fibromatose agressiva ou Tumor Desmoide (TD) é um tipo de neoplasia que se estende aos tecidos músculo-aponeuróticos, penetra cápsulas articulares, infiltra-se ao longo dos planos fasciais e invade estruturas neurovasculares adjacentes. Estima-se que sua incidência esteja entre 2-4:1.000.000, sendo mais frequente entre mulheres de 25 a 35 anos, principalmente durante ou após a gravidez. Representa 0,03\% de todas as neoplasias e 3\% dos tumores de partes moles. Esporadicamente (15\%) relacionam-se à síndrome de Gardner e Polipose Adenomatosa Familiar (FAP). Do ponto de vista patológico, são tumores benignos assemelhando-se a queloides e/ou fibromatose superficial. Sua classificaçăo baseia-se na localização, estando subdividido em intraabdominal, abdominal e extra-abdominal. Locais mais prevalentes são ombros, parede torácica, dorso, cintura pélvica e musculatura da coxa. O tratamento consiste principalmente em citorreduçâo cirúrgica com margens ampliadas, entretanto a incidência de recidiva local éalta, $65 \%$, mas a realizaçăo de radioterapia, quimioterapia e a utilização de drogas năo citotóxicas (AINE's, terapias hormonais e agentes biológicos) também devem ser consideradas, principalmente em casos irressecáveis. O presente trabalho relata o caso de um paciente, masculino, 24 anos, com histórico de citorredução cirúrgica para remoçăo de fibroma adenoide de dorso há dois anos, que se apresenta com nova lesão em mesma localizaçâa. Solicitados exames de imagem, constatou-se tumor em parede torácica, com extensão pleural, indissociável da musculatura paravertebral adjacente. Com esses dados, decidiu-se por nova citorreduçáo com exérese do tumor, em monobloco, toracotomia, apofisectomia $(\mathrm{T} 6, \mathrm{~T} 7, \mathrm{~T} 8)$ e osteotomia $\left(10^{\circ}, 11^{\circ}, 12^{\circ}\right)$, com posterior reconstruçáo e drenagem intercostal fechada. A anatomopatologia confirmou lesão fusocelular mesenquimal compatível com TD.

\section{Cirurgia de Tikhoff-Linberg: Relato de Três Casos e Revisão de Literatura}

Vieira $\mathrm{L}$, Oliveira AF, Fraga JBP, Santos LC, Costa RRL Associação Feminina de Prevenção e Combate ao Câncer (ASCOMCER) - Juiz de Fora (MG),

Publicada em 1928, a técnica de Tikhoff-Linberg (TL) vem sendo importante alternativa à técnica de Berger (amputaçáo interescapulotorácica), no tratamento de neoplasias, em regiâo de ombro e de cintura escapular. Isto fica mais evidente com a evolução das terapias quimioterápicas neoadjuvantes, permitindo cirurgias mais conservadoras. Classicamente, consiste na exérese da escápula, terço externo da clavícula e porção proximal do úmero, mantendo o braço. Somente é considerada em casos de tumores malignos da regiáo escapuloumeral, sem invasáo do feixe vasculonervoso, nem da parede torácica, que não apresentem comprometimento extenso de partes moles e não existam outras formas de tratamento mais conservadoras. A técnica de Tikhoff-Linberg oferece melhoria na qualidade de vida dos pacientes, no que diz respeito à funcionalidade e estética obtidas. Isso se deve à preservaçấo do feixe vasculonervoso, que mantém parcialmente os movimentos em articulação de punho e de cotovelo. O sucesso desse procedimento está associado a exames laboratoriais e de imagem, específicos para a clínica do tumor. Contudo há que se esclarecer ao paciente a possibilidade de conversão dessa para amputaçáo interescapulotorácica, pois a TL está diretamente relacionada com margens cirúrgicas oncologicamente adequadas. No presente estudo, os autores relatam três casos abordados pela técnica de Tikhoff-Linberg, na exérese de tumores em regiáo de ombro, no período de 2000 a 2008, no Hospital ASCOMCER em Juiz de Fora. Os pacientes tinham 50,6 anos em média e apresentavam as seguintes patologias de base: carcinoma basocelular recidivado em pele invadindo úmero, tumor gigantocelular e sarcoma de partes moles.

\section{A Produção Gráfica na Disseminação do Conhecimento Técnico-Científico no INCA \\ Moraes MCCP, Facina TF, Nascimento MA, Cerqueira ELSK, Alves, FL Instituto Nacional de Câncer (INCA), Rio de Janeiro (RJ), Brasil}

Introdução: No Instituto Nacional de Câncer (INCA), a produção gráfica de materiais é cada vez mais utilizada e reconhecida pelos profissionais, discentes e docentes da instituiçấo, uma vez que ela possibilita a disseminaçáo do conhecimento para fins educativos e técnico-científicos. Objetivos: O desenvolvimento de um fluxo de trabalho, com normas preestabelecidas, tem como objetivo preservar a identidade visual da instituiçáo, criando uma unidade entre os materiais e facilitando o entendimento das informaçóes e tornando-as mais atraentes. Material e métodos: A produção de materiais gráficos passa por diversas etapas, contando com o auxílio de diferentes equipes do Serviço de Edição e Informação Técnico-Científica/Coordenação de Educação, para a produção dos seguintes tipos de materiais: pôsteres científicos, fôlderes/lâminas, apresentaçóes para datashow, cartazes, materiais para divulgaçáo e utilizaçáo em eventos internos, $\mathrm{CDs}$, entre outras peças gráficas. Resultados e conclusão: A centralização da produção gráfica do INCA em um mesmo setor possibilita a criação de uma unidade nos materiais produzidos, facilitando a identificaçáo da instituição pelo público externo e auxilia os profissionais do Instituto na execução de seus projetos.

\section{Hemipelvectomia Interna: Relato de Seis Casos}

Oliveira AF, Vieira L, Vieira FJ, Santos LC, Costa RRL Instituto Oncológico / Hospital Monte Sinai - Juiz de Fora (MG), Brasil

Os ossos da regiáo da pelve são sede de menos de $5 \%$ dos tumores ósseos malignos. Aqueles mais comumente encontrados sáo o condrossarcoma, o sarcoma de Ewing e o osteossarcoma. Existem, basicamente, três tipos de tratamento cirúrgico para os tumores de pelve: amputação interilioabdominal, desarticulação coxofemural e hemipelvectomia interna. As duas primeiras consistem na desarticulação do membro, enquanto a terceira preserva o feixe vasculonervoso femoral e nervo isquiático, possibilitando a preservação do membro. Entende-se, por hemipelvectomia interna alargada, o procedimento, no qual, além dos segmentos ósseos e de tecidos ressecados na cirurgia clássica, removese, em monobloco, órgãos e estruturas adjacentes, que se apresentem macroscopicamente comprometidas. As hemipelvectomias são classificadas, segundo Enneking, em três tipos, ressecção da asa do osso ilíaco (Tipo I), da regiâo acetabular (Tipo II) e do ísquio e pube (Tipo III). O tipo IV consiste na ressecção de toda hemipelve. O presente trabalho faz o relato de seis pacientes submetidos à hemipelvectomia interna. A média de idade é de 31,34 anos (11 a 43 anos), três desses portadores de condrossarcoma pélvico, dois sarcomas de Ewing e um sacoma pleomórfico. Sendo uma modalidade de tratamento adequado para tumores de cintura pélvica, a hemipelvectomia interna consiste numa alternativa viável em relação à amputação interilioabdominal. Os principais fatores prognósticos para tumores de cintura pélvica são: grau de diferenciação tumoral e de comprometimento das margens cirúrgicas. Realizada dentro de princípios oncológicos, a cirurgia oferece altas taxas de cura e menor recidiva. 
Carcinoma Papilífero Renal em Paciente Idoso com DPOC: Relato de Caso

Andrade MR de, Castelo Branco MD de O, Vieira SA, Melo FM de, Souza MF de, Ataíde S de A Universidade Federal da Parába, Hospital Napoleão Laureano

Introduçáo: $\mathrm{O}$ carcinoma papilífero de células renais tem origem no túbulo renal e corresponde a $10 \%$ a $15 \%$ dos casos de tumores renais. Cerca de um terço dos pacientes apresenta tumor localmente avançado no momento do diagnóstico. A ressecção cirúrgica da lesão constitui o tratamento de escolha. $\mathrm{Na}$ população idosa, em virtude das comorbidades, o risco-benefício do tratamento deve ser levado em consideração. Nessa faixa etária, há maior chance de intercorrências clínicas. Objetivo: Relatar um caso de carcinoma papílifero de células renais em paciente idoso com DPOC. Metodologia: Avaliaçáo de prontuário do paciente do Hospital Napoleão Laureano, João Pessoa (PB). Resultados: F.A.S., 71a, sexo masculino, solteiro, agricultor, com diagnóstico de DPOC e Hipertensão Arterial. Procurou o Serviço de Urologia do HNL, queixando-se de hematúria macroscópica há um ano, associada à lombalgia. A tomografia demonstrou grande lesão expansiva heterogênea, medindo aproximadamente $11,0 \times 14,0 \times 13,0 \mathrm{~cm}$, localizada no rim direito, estendendo-se para o segmento VII do fígado, deslocando medialmente a veia cava superior. $\mathrm{O}$ paciente submeteu-se à ressecção cirúrgica de tumor retroperitoneal, apesar da idade e das doenças associadas (Goldman grau III). Durante o ato cirúrgico, desenvolveu uma bradicardia importante. No pós-operatório, permaneceu dois dias na UTI, sob ventilação mecânica, evoluindo com melhora clínica. O resultado anatomopatológico evidenciou carcinoma papilífero de origem renal ou da tireoide e a imunoistoquímica confirmou o diagnóstico histológico de carcinoma papilífero renal. Conclusáo: $\mathrm{O}$ tratamento ideal do carcinoma papilífero renal constitui a abordagem cirúrgica e, quando em pacientes idosos, requer do cirurgiăo oncológico maior habilidade, pois esses pacientes geralmente apresentam outras doenças associadas.

\section{Neurofibroma de Nervo Laríngeo Superior: Relato de Caso}

Andrade MR de, Loureiro AD, Castelo Branco MDO, Machado BB, Oliveira DHS de Fernandes KL Universidade Federal da Paraíba, Hospital Napoleão Laureano

Introdução: Neurofibroma é um tumor neurogênico benigno, originário da bainha das células de Schwann. Ocorre esporadicamente ou em associação a doença de Von Reclinhausen. $\mathrm{O}$ acometimento do nervo laríngeo superior é raro e acomete mais mulheres que homens (razáo de 3:2). Os sintomas mais comuns são rouquidão, dispneia e disfagia. Os sítios mais prevalentes são a aritenoide e prega ariepiglótica. A cirurgia conservadora é o tratamento de escolha. Objetivo: Relatar um caso de neurofibroma de nervo laríngeo superior. Metodologia: Relato de caso a partir da avaliação clínica, cirúrgica e análise de prontuário do paciente tratado no setor de Cirurgia de Cabeça e Pescoço do Hospital Napoleão Laureano (HNL). Resultados: J.R.B.S., 47a, pardo, casado, aposentado, natural e procedente de João Pessoa (PB). Procurou o HNL, queixando-se de disfonia há quatro anos. A laringoscopia com telescópio rígido demonstrou lesão submucosa, arredondado na hemilaringe esquerda, obstruindo quase por completo a glote e acometendo a prega ariepiglótica. A tomografia mostrava uma massa sólida bem delimitada, sem necrose central e sem extensão para planos profundos, medindo aproximadamente $5 \mathrm{~cm}$. Foi realizada uma faringotomia lateral suprahioidea via cervical com ressecção completa da lesão. O resultado anatomopatológico evidenciou tumor benigno de nervo periférico, sugerindo ser neurofibroma ou schwannoma. A imunoistoquímica confirmou o diagnóstico histológico de neurofibroma. O paciente evoluiu com melhora clínica e remissão da sintomatologia. Conclusão: O neurofibroma de laríngeo superior é um tumor benigno raro e a cirurgia conservadora é o tratamento padrão.
Amputação Transmetatarsiana de Hálux em Tratamento de Sinoviossarcoma: Revisão Literária e Relato de Caso

Oliveira A F, Vieira L J, Ghetti TM, Nascimento ACR, Costa RRL Hospital João Felício - Juiz de Fora (MG), Brasil

O sinoviossarcoma é reconhecido como uma neoplasia de partes moles de alto grau de malignidade, que apresenta altas taxas de recidiva e metástases. Não há um consenso na literatura avaliada, com relação à taxa de sobrevida após cinco anos do diagnóstico, variando de 5\% a 64\%, mas não há dúvidas sobre a proporção significante de letalidade que essa doença representa para alguns pacientes. Embora o sinoviossarcoma seja um tumor pouco frequente, ocupa a terceira posição no tipo histológico mais comum entre os sarcomas de partes moles. Por ser um sarcoma que acomete regióes justarticulares, o sítio de maior ocorrência são os joelhos, contudo encontramos com frequência próximo a outras articulaçôes (tendōes, bursas e cápsulas). Acometem mais adultos jovens, com uma clínica peculiar, em relação a outros tipos de sarcoma, pois cursam com intensa dor local. O padrấo ouro de tratamento para tal neoplasia é a ressecção em monobloco, reservando a amputação para lesôes presentes em extremidades. O subtipo histológico, o grau de diferenciação, a ploidia do tumor, seu tamanho e localização são aspectos a se considerar para viabilidade de cura; enquanto que a presença de áreas de necrose representa fator de pior prognóstico. Diante da baixa recorrência os autores, através do presente trabalho, relatam o caso de uma paciente de 48 anos, sexo feminino, diagnosticada com sinoviossarcoma de hálux direito e que foi submetida a uma amputação transmetatarsiana com resseção R0.

\section{Diagnóstico Intra-Operatório de Feocromocitoma: Revisão Literária e Relato de Caso}

Vieira L, Oliveira AF, Fraga JBP, Costa RRL, Nascimento ACR Hospital e Maternidade Monte Sinai - Juiz de Fora (MG), Brasil

Derivados de células cromafins, os feocromocitomas são tumores raros (1:1000), em sua maioria benignos e unilaterais $(90 \%)$, caracterizados pela produção de catecolaminas. Sua incidência é maior nas $3^{\mathrm{a}}$ e $4^{\mathrm{a}}$ décadas de vida, sem distinçóes entre sexo. Apresentam ampla sintomatologia, como alteraçốes cardiovasculares, cefaleia e sudorese. São de grande importância no diagnóstico diferencial de hipertensão arterial refratária (HAR). Geralmente encontrados na glândula adrenal, podem ocorrer em outras regiōes anatômicas, sendo denominados paragangliomas. Em casos assintomáticos, o diagnóstico é difícil e até mesmo incidental (1\% a 4\%), reservado para situaçôes em que é feito durante screening de síndromes familiares como neoplasia endócrina múltipla do tipo II, doença de Von Hippel-Landau e neurofibromatose I. Quando malignos (10\%), os sítios de metástases frequentemente são ossos, fígado e pulmão. Esses tumores podem secretar episodicamente catecolaminas, porém metabolizam-nas em metanefrinas continuamente, por isso a dosagem de metanefrinas urinária e plasmática são métodos de maior acurácia para o diagnóstico. A cirurgia é a principal forma de tratamento, embora haja controvérsia quanto à técnica mais adequada. A abordagem laparoscópica reserva-se para tumores restritos à supra-renal, menores que $6 \mathrm{~cm}$ e sem invasão de estruturas adjacentes. Os autores relatam o caso de uma paciente, sexo feminino, 68 anos, com história prévia de HAR e tomografia abdominal evidenciando imagem tumoral $(5 \mathrm{~cm})$ em supra-renal direita. Após avaliação bioquímica urinária normal, foi submetida à cirurgia para ressecçáo do tumor. Durante o ato operatório, observou-se grande oscilaçâo da pressão arterial sistólica (60$320 \mathrm{mmHg}$ ) ao manipular o tumor; fechando o diagnóstico intra-operatório em feocromocitoma. 


\section{Linfoma Primário de Reto: Relato de Caso e Revisão de Literatura}

Leite DRC, Sousa TTS, Leite RRC, Sousa TIS, Costa TC Universidade Federal da Paraíba, Hospital Napoleão Laureano

Introduçáo: Linfomas primários do reto são muito raros, representando menos de $1 \%$ dos tumores malignos do intestino grosso. Os principais sintomas são sangramento anal, melena e constipação, sendo clinicamente indistinguíveis do carcinoma do reto. Pacientes tratados cirurgicamente têm um prognóstico melhor, mas devem ser consideradas quimioterapia e/ou radioterapia em alguns casos. Objetivos: Relatar o caso de um linfoma primário de reto em paciente atendida no Hospital Napoleão Laureano. Material e Método: Acompanhamento retrospectivo por consulta de prontuário e entrevistas à equipe médica. A revisão de literatura foi baseada nas bases de dados Medline e Pubmed. Resultados: MJL, mulher, branca, heterossexual, 40 anos, natural de Patos, Paraíba. Referia dor anal e evacuaçóes de sangue vivo há quatro meses; ao exame proctológico, a região anal era hiperemiada, edemaciada e endurecida. Sorologia pra HIV negativa. Levantou-se a hipótese de abscesso perirretal e de processo expansivo. Foi indicada retossigmoidoscopia com biópsia da lesão. Pelo estudo histopatológico, identificou-se tumor maligno primário de reto, tipo Linfoma de Hodking, que acometia toda a parede do órgão. Devido à extensão tumoral, não foi recomendada intervenção cirúrgica. Foi encaminhada para Hematologia e atualmente está em uso de esquema quimioterápico, com prognóstico ruim. Conclusáo: O linfoma colorretal primário é uma afecção rara que apresenta pior prognóstico quando comparado com o linfoma gástrico primário e com adenocarcinoma do cólon. Faz-se, então, necessária uma maior investigaçáo dos linfomas primários de reto.

\section{Borderline Serous and Mucinous Ovarian Tumors: Experience of 10 Years}

Reis J, Patury P, Santos L, Barakat M, Derchain S, Silva IF Serviço de Ginecologia Oncológica/ Instituto Nacional de Câncer (INCA)/MS - Rio de Janeiro (RJ), Brazil

Aims: Borderline ovarian tumor account for $15 \%$ to $20 \%$ of epithelial ovarian cancers and occurs in women in the reproductive age group. Methods: Retrospective study of borderline ovarian tumors treated at Gynecologic Oncologic Department at Brazilian National Cancer Institute (INCA) between January 1997 and October 2007. Results: There were 122 cases selected by histopathology. The mean age was 49 (17-83) years. Thirty two patients (26.2\%) had Ca $125>35 \mathrm{U} / \mathrm{ml}$, with mean of 172 (36.3-1.182) U/ml. Histological origin was as follows: 59 cases of mucinous (48.3\%), 57 (46.7\%) serous and 6 (5\%) seromucinous. Majority of the cases (95\%) were stage I (Ia,76.2\%; Ib, 9.8\%; Ic, 9\%). Two patients (1.6\%) had stage II (IIa/IIc); one $(0.9 \%)$ had stage IIIa; and three $(2.5 \%)$ were stage IIIb. There was not stage IV. Sixty seven women (55\%) underwent primary surgical procedure at INCA. Of 55 patients $(45 \%)$ operated in others hospitals, 38 had complete surgery in our institution. There were changing of stage in 7 cases (18.4\%): $5 \mathrm{Ia}$ became Ib(3) and Ic(2); and $2 \mathrm{Ib}$ to IIIc. In 28 cases $(23 \%)$ had fertility-sparing surgery. Adjuvant chemotherapy was administered in 3 patients (2.5\%). The mean follow-up was 56,8 months, with $2(1.6 \%)$ recurrences. There were four deaths $(3.3 \%)$, not due to neoplasm. Conclusion: The surgical staging of borderline tumors must be meticulous, although had been not consensus about adjuvant therapy. These tumors appear favorable behavior than carcinomas, with lower recurrence and the fertility-sparing surgery is a safe procedure.
Gastrectomia em Paciente com Situs Inversus Totalis

Vieira $\bigsqcup$ Oliveira AF Vieira FJ, Costa RRL, Nascimento ACR Associação Feminina de Prevenção e Combate ao Câncer (ASCOMCER) - Juiz de Fora, (MG),

Brasil

Situs inversus é uma anomalia anatômica rara (1/8.000-1/25.000) com inversão de posição das vísceras (imagem de espelho) e está associada a defeitos cardíacos congênitos. Quando há levocardia, é chamado situs inversus totalis e a incidência de cardiopatia congênita é 3\%-5\%. Uma revisão da literatura mostrou menos de 40 casos contendo a associação câncer gástrico e situs inversus. O estudo anatômico pré-operatório é importante para guiar cirurgias diante dessas alteraçóes. Cirurgia é o padrão ouro para cura do câncer gástrico; nos tumores distais, preconiza-se gastrectomia subtotal, já que se pode obter margens adequadas $(6 \mathrm{~cm})$, menor morbidade e sobrevida semelhante à gastrectomia total. Extensão da linfadenectomia ainda é controversa, mas estudos recentes demonstraram que linfadenectomia D2, preferencialmente poupando pâncreas e baço, pode ser realizada com baixa morbidade e chance de maior sobrevida. Relatamos um caso de um paciente, 55 anos, masculino, ex-tabagista, com perda ponderal, dor epigástrica e anemia. Apresentava marcapasso definitivo e hipertensão arterial controlada por medicamentos. Endoscopia digestiva evidenciou tumor em antro gástrico. Raios-X torácico detectou dextrocardia com cardiomegalia e tomografia computadorizada confirmou situs inversus totalis. Realizou-se gastrectomia subtotal com linfadenectomia D2 e anastomose Y-de-Roux pré-cólica. $\mathrm{O}$ anatomopatológico confirmou adenocarcinoma invasor pouco diferenciado. Durante ato cirúrgico, houve dificuldades técnicas inerentes à variação anatômica, exigindo troca de posiçáo do cirurgião frequente para facilitar acesso cirúrgico; procedimento passível de realização, contudo vale ressaltar importância do cirurgião estar habituado com tipo de cirurgia e da necessidade de estadiamento pré-operatório. 106

\section{Endometrioid Borderline Ovarian Tumor: a Rare Tumoral Type}

Santos L, Patury P, Reis J, Barakat M, Derchain S, Guitmann G Serviço de Ginecologia Oncológica/ Instituto Nacional de Câncer (INCA)/MS - Rio de Janeiro (RJ), Brazil

Aim: Borderline ovarian tumors account for $15 \%$ of all epithelial ovarian Neoplasms. The incidence of endometrioid type is less than 3\%. This report discusses the cases of 4 patients with the diagnosis of endometrioid borderline ovarian tumors, one of those presenting with synchronous endometrioid endometrial Cancer. Methods: Retrospective review of cases treated at Gynecologic Oncologic Department at the Brazilian National Cancer Institute between 1999-2009. Results: We reviewed four cases with the diagnosis of endometrioid borderline ovarian tumor. All cases $(n=04)$ were submitted to surgical treatment. Three of them received complete surgery (total extrafascial hysterectomy, bilateral salpingo-oophorectomy, pelvic and para-aortic lymph node dissection and omentectomy) and the other one was submitted to a unilateral ooforectomy. Two patients were nulliparous in fertile age (19, 26, 59, 70 years). The youngest patient (19 years old) presented with synchronous endometrioid endometrial cancer (stage IIA). At surgical staging, Stage IA of ovarian neoplasm was found in all patients. During follow-up period there was no evidence of recurrence. Conclusion: The simultaneous appearance of primary ovarian and endometrial carcinoma is rare ( $0.3 \%$ of the genital tract malignancies). In the case of synchronous detection of neoplasms of endometrium and ovary with similar histologic features, the distinction between two independent primary tumors based on conventional clinicopathologic criteria may be difficult. The rarity of endometrioid borderline ovarian tumor is an incentive to researches, in order to better understanding its fisiopathogeny and finding new therapeutic perspectives. 


\section{Assistência de Enfermagem Sistematizada ao \\ Paciente Portador de Tumor Cerebral com Hipertensão Intracraniana}

Souza AS, Oliveira IR, Camargo MCM, Silva SL, Percínio MLL, Beildeck GE
Instituto Nacional de Câncer (INCA)/MS - Rio de Janeiro /RJ

O tumor cerebral tem sido motivo de muitos estudos clínicos, não devido à existência de uma causa isolada, e sim à combinaçăo de fatores como: alteraçôes genéticas, hereditariedade, exposição a substâncias químicas, hormônios, condiçôes ambientais e ocupacionais. Segundo Govidan e Arquette, há uma relação direta dos déficits neurológicos acometidos pelo tumor como: motor, cognitivos, visuais, motores, deglutiçáo, entre outros, uma vez que o tumor cerebral originado do próprio tecido evolui com compressão e destruição de estruturas neurológicas. Qualquer situação que contribua para o aumento da pressáo intracraniana (PIC) ocorrerá à diminuiçáo dos outros componentes, para que não ocorra aumento da PIC. As manifestações clássicas da hipertensão intracraniana (HIC) são: cefaleia, alteraçóes visuais, náuseas, vômitos e papiledema. $\mathrm{O}$ tratamento do HIC visa à remoçáo das lesóes expansivas e medidas concomitantes ou de emergência como: drenagem ventricular externa (DVE) ou derivação ventriculoperitoneal (DVP). Este trabalho objetiva identificar os principais diagnósticos de enfermagem em pacientes neurocirúrgicos oncológicos com HIC com base na NANDA Internacional e relacionar, a partir dos diagnósticos, as intervençôes de enfermagem correspondentes. Realizamos uma revisão de literatura sobre o tema nos últimos cinco anos, nas bases: Lilacs, Medline, SciELO, livros, e a experiência das autoras na prestação da assistência ao paciente com tumor do sistema nervoso central. É fundamental o conhecimento técnico-científico do enfermeiro para identificar precocemente os sinais e sintomas do paciente com HIC e, através de seu julgamento clínico, estabelecer os diagnósticos de enfermagem apropriados e as intervençóes correspondentes, permitindo uma assistência de enfermagem individualizada.

109

\section{Assistência de Enfermagem Sistematizada de Enfermagem ao Paciente com Câncer de Pulmão}

Souza AS, Damazio TM, Menezes CMP, Guimarães RC, Oliveira MSG, Souza CR Hospital do Câncer I (HCI)/Instituto Nacional de Câncer (INCA)/MS - Rio de Janeiro (RJ), Brasil

O câncer de pulmão é considerado um problema de saúde pública e com crescimento em sua incidência mundial de $2 \%$ ao ano. Segundo estimativa para 2010, a incidência de câncer no Brasil (INCA) é de 17.800 entre homens e de 9.830 nas mulheres. O tabagismo é o principal fator de risco do câncer de pulmão, sendo responsável por $80 \%$ a $90 \%$ dos casos. Estudos epidemiológicos apontam outros fatores de risco como: exposição ao asbesto, gás radioativo radônio, urânio, arsênio, cromados de níquel, cloreto de vinil, carvão mineral, gás de mostarda, poluição do ar, infecções pulmonares de repetição e deficiência ou excesso de vitamina A. Este trabalho tem como objetivo identificar os principais diagnósticos de enfermagem em pacientes com câncer de pulmâo com base na taxonomia da NANDA e relacionar, a partir dos diagnósticos de enfermagem identificados, as intervençôes de enfermagem correspondentes com base na NIC. Foi realizada uma pesquisa bibliográfica sobre o tema nos últimos cinco anos, nas bases: Lilacs, Medline, SciELO, livros, e a experiência das autoras na prestação da assistência ao paciente com câncer de pulmão. Esse processo de identificação se deu a partir da relação de problemas/alteraçôes com os diagnósticos de enfermagem de acordo com suas características definidoras, fatores relacionados e fatores de risco. A produção científica na área de enfermagem em cirurgia torácica oncológica é escassa, evidenciando a relevância da assistência de enfermagem sistematizada nessa área específica e o estabelecimento de intervençốes de enfermagem de forma individualizada, favorecendo a recuperação dos pacientes e padronização da linguagem de enfermagem.
A Influência da Margem Cirúrgica no Tratamento do Dermatofibrossarcoma Protuberans

Reis J, Resende F, Vasconcelos RAT, Fiod N, Rezende JFN, Barros A Serviço de Cirurgia dos Tecidos Ósseos e Conectivos/Instituto Nacional de Câncer (INCA)/

MS - Rio de Janeiro (RJ), Brasil

Objetivo: O Dermatofibrossarcoma Protuberans (DFSP) é um tumor localmente agressivo com recidiva precoce após ressecçōes marginais. Nesse trabalho, foi avaliado o status da margem de ressecção e recidiva em longo prazo. Material e Métodos: Estudo retrospectivo dos casos de DFSP tratados no Instituto Nacional de Câncer (INCA) no período de 1990 a 2004. Excluídos os pacientes com margens de ressecçẫo positivas, doença metastática e tumores em topografia de cabeça e pescoço. Resultados: Dos 87 casos de DFSP, 12 perderam seguimento. Dos 75 pacientes, $57(76 \%)$ apresentavam tratamento prévio, a maioria $(73,6 \%)$ submetida a uma ressecção. A idade média foi de 39 (13-78) anos. A média do tamanho das lesóes foi de 4,4 $(0,5-15) \mathrm{cm}$. Dos pacientes admitidos no INCA, $71(94,6 \%)$ casos foram submetidos a tratamento cirúrgico, ressecção ou ampliação, e quatro $(5,4 \%)$ foram acompanhados ambulatorialmente. Sessenta e cinco $(86,6 \%)$ dos pacientes tiveram margens de ressecçấo analisadas, com média de 1,6 $(0,1-4) \mathrm{cm}$. Os pacientes foram divididos quanto ao status da margem de ressecção: $\leq 1 \mathrm{~cm}, 24(36,9 \%)$ casos; $1 \mathrm{~cm}<\mathrm{e} \leq 2 \mathrm{~cm}, 27(41,5 \%)$ casos; $2 \mathrm{~cm}<\mathrm{e} \leq 3 \mathrm{~cm}, 10(15,4 \%)$ casos e $>3 \mathrm{~cm}, 4(6,2 \%)$ casos. O tempo médio de acompanhamento foi 71,4 meses (6-195). Ocorreram duas $(2,6 \%)$ recidivas locais, nenhuma a distância ou óbito. Conclusão: O DFSP deve ser tratado em centros especializados para evitar múltiplas ressecçóes e deformidades anatômicas. A recidiva local está diretamente relacionada às margens de ressecção, contudo a margem de ressecção adequada ainda se mantém indefinida na literatura.

\section{Gastrostomia Paliativa no Paciente Oncológico: Experência do INCA}

Barros A, Reis J, Maciel A, Barakat M, Fernandes DS, Santos L Serviço de Cuidados Paliativos/Instituto Nacional de Câncer (INCA)/MS - Rio de Janeiro (RJ), Brasil

Objetivos: Relatar a experiência do Instituto Nacional de Câncer (INCA) com a realização da gastrostomia cirúrgica em pacientes sob cuidados paliativos. Material e Método: Análise prospectiva dos pacientes submetidos à gastrostomia cirúrgica na Unidade de Cuidados Paliativos do INCA, no período de Janeiro/2005 a Junho/2008. Resultados: Foram selecionados 73 pacientes com média de idade 56 (35-82) anos e predomínio do sexo masculino (81\%). Um paciente $(1,3 \%)$ foi submetido à gastrostomia para descompressão intestinal. O principal motivo para realização da gastrostomia foi disfagia, ocorrida em $62(84,9 \%)$ casos de tumores de cabeça e pescoço, seguido de sete $(9,5 \%)$ casos de tumores esofágicos, e três $(4,2 \%)$ outros. A média do valor da albumina no pré-operatório em 71 (97,2\%) pacientes foi de 2,95 (1,5-4,6) mg/dl. Quarenta e três (59\%) pacientes apresentavam Karnofsky Performance Status (KPS) $>50 \%$ e $30(41 \%)$ com KPS $\leq 50 \%$ no pré-operatório. Complicaçōes pós-operatórias ocorreram em 12 (16,4\%) casos, sendo três (25\%) nâo relacionadas ao sítio cirúrgico (Pneumonia (n=2) e AVE). Dos nove (75\%) pacientes com complicaçôes relacionadas ao sítio cirúrgico, seis $(50 \%)$ apresentaram extravasamento peri-gastrostomia, dois $(16,6 \%)$ infecção ferida cirúrgica e um $(8,3 \%)$ peritonite. A sobrevida média após realização da gastrostomia foi de 74,4 (1-435) dias. Nenhum óbito foi relacionado ao procedimento cirúrgico. Conclusão: A gastrostomia cirúrgica é factível e segura para paliação de pacientes oncológicos, com baixas taxas de complicaçóes. Os pacientes devem ser selecionados para gastrostomia, utilizando critérios como KPS, pois aqueles com sobrevida muito curta não se beneficiam do procedimento. 
Avaliação dos Resultados de 70 Gastrectomias

Consecutivas: Análise de Mortalidade e

Morbidade

Ribeiro EA, Carrizo FD, Souza JC Hospital do Câncer de Muriaé - Muriaé (MG), Brasil

Introduçáo: $\mathrm{O}$ câncer gástrico representa importante problema de saúde pública, sendo em algumas regiôes o câncer gastrointestinal mais frequente. Portanto é muito importante a avaliação das estratégias atuais de tratamento e seus resultados. Objetivos: Avaliar os resultados do tratamento cirúrgico do câncer gástrico através da análise das taxas de radicalidade, mortalidade e morbidade, número de linfonodos dissecados e sobrevida. Métodos: Analise retrospectiva de 70 gastrectomias com linfadenectomia D1 (paliativa) e D2 (curativa) consecutivas, realizadas por um único cirurgião em nosso hospital no período de dezembro de 2004 até agosto de 2009. Resultados: A taxa de mortalidade pós-operatória foi de $7 \%$, sendo $45 \%$ dos óbitos por complicaçóes cirúrgicas e $55 \%$ por causas clínicas. Como complicaçáo maior que exigiu recuperaçáo tivemos dois casos de sangramento e um de obstruçăo intestinal. O número médio de linfonodos dissecados nas gastrectomias D2 foi de 33,7, sendo o mínimo de 18 e o máximo de 69. Conclusão: Nossas taxas de mortalidade e morbidade são semelhantes às dos demais centros de referência de tratamento oncológico. A radicalidade cirúrgica foi demonstrada pela quase totalidade dos casos serem submetidos à ressecçáo completa e pelo número de linfonodos dissecados estar acima dos 25 linfonodos preconizados. No seguimento para análise de sobrevida, a maioria dos pacientes se encontrava vivo e sem doença ativa. Com isso, nossos resultados demonstram que pacientes tratados com cirurgia radical curativa e com atençâo multidisciplinar, integrando radioterapia e quimioterapia, num hospital especializado em tratamento oncológico do interior e por profissionais especializados, têm resultados semelhantes a outras instituiçôes oncológicas do País.

\section{Tumor Estromal Extragastrointestinal (EGIST): Casuística do Instituto Nacional de Câncer}

\author{
Barros A, Linhares E, Bandeira D, Gonçalves R, Reis J, Vilhena B \\ Serviço de Cirurgia Abdominopélvica/ Instituto Nacional de Câncer (INCA)/MS - Rio de \\ Janeiro (RJ), Brasil
}

Objetivos: Relatar a casuística do Instituto Nacional de Câncer (INCA) dos tumores estromais extragastrointestinais (EGIST). Material e Método: Foram analisados, retrospectivamente, 142 pacientes com diagnóstico de GIST tratados no INCA entre 1997 e 2009, entre os quais, nove foram EGIST. Resultados: Identificamos nove pacientes com o diagnóstico de EGIST, sendo sete $(77,8 \%)$ do sexo feminino com média de idade de 56,8 (36-81) anos. Todos os pacientes eram sintomáticos, com a dor abdominal presente em $55 \%$ dos casos. Os tumores estavam localizados no pâncreas $(n=2)$, retroperitôneo $(n=3)$ e, respectivamente, um em: mesocólon, mesentério do intestino delgado, baço e pelve. A média do tamanho tumoral foi de $18(8,5-27) \mathrm{cm}$. CD117 foi positivo em $100 \%$ dos casos. Cinco pacientes foram tratados cirurgicamente, sendo três submetidos à ressecção R0. Todos pacientes recidivaram com 31, 23 e 17 meses respectivamente, sendo o fígado e o peritôneo os sítios mais frequentes. Destas três recidivas, duas $(66 \%)$ foram resgatadas cirurgicamente. Os pacientes considerados irressecáveis ( $\mathrm{n}=3$ ), um submetido à cirurgia $\mathrm{R} 2$ e o outro que recidivou não resgatado cirurgicamente, foram tratados com imatinibe. Dois pacientes não receberam tratamento com imatinibe por condiçôes clínicas comprometidas. A sobrevida global média foi 26,4 (04-114) meses. Conclusão: A ocorrência dos EGIST é extremamente rara e pouco se sabe sobre sua real origem. Manifestam-se com volumosas massas, o que compromete o prognóstico. A abordagem cirúrgica agressiva é o tratamento mais efetivo associado ao uso de imatinibe, e um seguimento prolongado é necessário devido à alta taxa de recorrência.
Immature Ovarian Teratoma: Analises of 21 Cases

Santos L, Martins MR, Patury P, Chaves CBP, Reis J, Prisco E Serviço de Ginecologia Oncológica/ Instituto Nacional de Câncer (INCA)/MS - Rio de Janeiro

(R), Brazil

Aims: Ovarian immature teratoma represents less than $1 \%$ of ovarian malignant tumors, its prognosis is directly correlated to histologic grade and mostly occurs in young women. We review the outcome of treatment in patients with immature ovarian teratoma. Methods: Retrospective study of immature ovarian tumors treated at Gynecologic Oncologic Department at Brazilian National Cancer Institute between september/1998 and august/2007. Results: Twenty-one cases were selected. The mean age was 14 (6-49) years and 13 patients (62\%) were nulliparas. Abdominal pain occurred in $66.7 \%$ cases and palpable abdominal mass in $62 \%$. The mean tumoral size was 16 (6-27) $\mathrm{cm}$. Seventy six percent of patients were FIGO stage I (Ia, 57\%; Ib, 4.8\%; Ic, 14.3\%) and 24\% were stage III (IIIa, 9.6\%; IIIc, $14.3 \%)$. Fertility-sparing surgery, unilateral salpingo-oophorectomy, was done in 12 cases (57\%). Adjuvant chemotherapy was administered in 11 patients stage Ib/Ic/IIIa/IIIc (52.3\%). Complete response was obtided in cases with more than three cycles. Only two patients presented grade III tumors. The recurrence rate was $14.3 \%$ in 3 and 5 years. One patient grade III presented recurrence with one year. The overall suvival was 46 (3-125) months and disease-free survival was 43 (0-125) months. There was one death and three patients were alive with recurrence. Conclusion: The immature ovarian teratoma stage Ia, Grade I/II, should be treated only with conservative surgery. However, these tumors present high sensibility to chemotherapy, and in advanced stages, the fertility-sparing surgery can be used follow by chemotherapy.
Avaliação dos Resultados de Ressecçóes Duodenopancreáticas Consecutivas: Análise de Mortalidade e Morbidade

\section{Ribeiro EA, Carrizo FD, Souza JC Hospital do Câncer de Muriaé - Muriaé (MG), Brasil}

Introduçáo: $\mathrm{O}$ câncer de pâncreas representa um grave problema de saúde pública, pelos seguintes aspectos: alta taxa de mortalidade, falta de métodos adequados e efetivos de prevençáo e detecçáo precoce e complexidade no tratamento cirúrgico, sendo a gastroduodenopancreatectomia (GDP) ou a duodenopancreatectomia (DPT) as técnicas preconizadas. Essas técnicas também são a de escolha para o tratamento de tumores periampulares com colangiocarcinomas, tumores de papila duodenal e tumores de duodeno. Objetivos: Avaliar os resultados das GDP e das DPT, mais precisamente através da análise das taxas de radicalidade, mortalidade e morbidade, e número médio de linfonodos dissecados. Métodos: Analise retrospectiva de 12 ressecçôes consecutivas realizadas por um único cirurgiáo em nosso hospital, no período de dezembro de 2004 ate agosto de 2009. Resultados: Não houve mortalidade nessa série. Apenas um paciente apresentou complicação maior, fístula gástrica que foi tratada clinicamente. Os pacientes foram realimentados em média entre o quarto e o quinto dia de pós-operatório e a alta hospitalar foi em média no oitavo dia de pós-operatório. Todos os casos oncológicos foram ressecados com margens negativas e com número adequado de linfonodos. Conclusáo: Nossas taxas morbidade foram pequenas e a de mortalidade nula nessa pequena série. A radicalidade cirúrgica foi obtida em todos os casos e o número de linfonodos dissecados foi dentro do preconizado. Com esses resultados iniciais, concluímos que estamos aptos para realizaçấo de ressecçôes duodenopancreáticas e com isso buscaremos aumentar nossa casuística para nos tornarmos um centro de referência para o tratamento cirúrgico das afecçôes duodenopancreáticas periampulares. 


\section{Aspectos Técnicos da Cirurgia Citorredutora e Quimioterapia Hipertérmica Intraperitoneal (HIPEC)}

Miranda Brandão E, Rino M, Santos R, Macêdo M, Miranda Brandão P, Sobral L
Hospital Esperança - Clínica Unionco - Faculdade de Ciências Médicas - UPE
Recife (PE), Brasil

Introduçáo: A carcinomatose peritoneal é uma condição uniformemente fatal em curtos períodos (sobrevida média de seis meses) quando tratada de maneira clássica com cirurgia citorredutora e quimioterapia sistêmica. $\mathrm{O}$ advento das cirurgias citorredutoras alargadas seguidas de quimioterapia intracavitária hipertérmica permitiu sobrevidas maiores: 50\% em quatro anos para tumores de ovário, $44 \%$ em dois anos para carcinoma colorretal e $97 \%$ em cinco anos para pseudomixoma peritoneal. Métodos: São relatados os aspectos técnicos e pós-operatórios de quatro pacientes submetidos à HIPEC no ano de 2008. Resultados: Foram realizados quatro casos, sendo os três primeiros de tumores de apêndice (adenocarcinoma) e o último de carcinoma de ovário. A duração da cirurgia oscilou de 11 a 18 horas e a da internação de 14 a 62 dias. Nos três casos iniciais houve citorreducão completa (ICR-CC0), e o caso restante foi qualificado como ICR CC1 (lesóes remanescentes de até 0,25 cm). Complicações: pneumonite persistente, insuficiência respiratória prolongada por SARA, insuficiência renal aguda e síndrome de resposta inflamatória difusa (SRID). Os três primeiros pacientes encontram-se assintomáticos, sem evidências de recidiva, com boa qualidade de vida ao $13^{\circ}, 11^{\circ}$ e $9^{\circ}$ mês de seguimento, respectivamente. O último paciente evoluiu para óbito consequente a SRID, no 33 DPO. Conclusáo: Diante da experiência inicial, observa-se um alto índice de complicaçōes pós-operatórias e um longo período de internamento, embora se perceba um resultado favorável na sobrevida dos pacientes com citorreducáo total quando comparada à abordagem clássica. Evidencia-se a importância de protocolos multicêntricos, essenciais para a consolidação da HIPEC ao arsenal oncológico.

117 Amputação e Desarticulação no Tratamento de
Carcinomas Escamocelular Cutâneos

Barakat M, Reis J, Barros A, Vasconcelos RAT, Fiod N, Rezende, JFN Serviço de Cirurgia dos Tecidos Ósseos e Conectivos/Instituto Nacional de Câncer (INCA)/ MS - Rio de Janeiro (RJ), Brasil

Objetivo: O carcinoma escamocelular (CEC) da pele apresenta comportamento indolente, porém, se não tratado precocemente, pode progredir para formas avançadas, necessitando de amputaçáo para controle local da doença. Neste estudo, analisamos as características dos pacientes com CEC avançado de extremidades submetidos à amputaçáo. Material e Método: Estudo retrospectivo dos casos de CEC de extremidades tratados com amputação no Instituto Nacional de Câncer (INCA) no período de Fevereiro de 1997 até Outubro de /2003. Resultados: Foram selecionados 98 pacientes portadores de CEC, com idade média 66 (21-89) anos. Somente 23 (24,7\%) pacientes apresentavam insuficiência vascular periférica, no entanto $42(45,6 \%)$ pacientes eram tabagistas. $\mathrm{O}$ tempo médio de evoluçấo dos sintomas foi de 104 meses. Ocorreu maior comprometimento em membros inferiores $(76,6 \%)$ com predominância na perna $(49 \%)$. O nível de amputação mais frequente foi em coxa $(37,7 \%)$. Quanto ao grau de diferenciaçáo ocorreram GI, 58\%; GII, 34\%; GIII, 8\%. Linfonodos clinicamente positivos foram identificados em 44 casos (45\%), sendo 19 casos (43\%) confirmados no estudo histopatológico. Cinco pacientes apresentaram margens de ressecção comprometidas, sendo quatro casos com invasão óssea. Destes, o paciente sem invasáo óssea apresentou melhor sobrevida livre de doença (35 meses). Um paciente com margem positiva e invasão óssea, foi tratado com cirurgia de Berger e apresentou recidiva com dois meses. Os pacientes tiveram média de follow-up de 46 meses. A taxa de recorrência foi de $20 \%$ e a sobrevida média foi de 35 meses. Conclusáo: Os carcinomas escamocelular avançados de pele apresentam alto risco para linfonodos metastáticos. A amputação é um último recurso para controle local da doença, mantendo, ainda, taxas de recidiva relevantes.

118

\section{Implicações do Fracionamento de Dose na Radioterapia}

Leite DRC, Sousa TTS, Leite RRC, Sousa TTS, Barbosa IJS
Universidade Federal da Paraíba, João Pessoa (PB), Brasil

Ribeiro EA, Carrizo FD, Souza JC Hospital do Câncer de Muriaé - Muriaé (MG), Brasil

Introduçáo: $\mathrm{O}$ câncer de esôfago representa importante problema de saúde publica, em algumas regiôes é o terceiro câncer gastrointestinal mais frequente. Devido à anatomia eà complexidade cirúrgica, o câncer de esôfago representa um desafio para o cirurgiáo. Objetivos: Avaliar os resultados do tratamento cirúrgico do câncer de esôfago. Métodos: Análise retrospectiva de 35 esofagectomias consecutivas realizadas pelo mesmo cirurgião, (14 transmediastinal, 11 transtorácica) no período de dezembro de 2003 até agosto de 2009. Resultados: A ressecção não foi R0 em dois pacientes, um caso R2 e outro de ressecçấo R1. A taxa de mortalidade pós-operatória foi de $15 \%$, sendo que $60 \%$ dos óbitos foram por complicaçôes clínicas e $40 \%$ por complicaçôes cirúrgicas, por fístula da anastomose esofagogástrica intratorácica e mediastinite e por fístula quilosa. O número médio de linfonodos dissecados foi de 24,5, sendo o mínimo de 11 e o máximo de 43. Quatorze pacientes estão vivos e 16 pacientes morreram de câncer. Todos pacientes submetidos à esofagectomia não apresentaram recidiva da disfagia. Conclusáo: Nossas taxas de mortalidade e morbidade são aceitáveis e se encontram dentro da média na literatura. O número médio de linfonodos dissecados foi dentro do preconizado na literatura. Cerca de um terço dos pacientes estão vivos com seguimento médio de mais de dois anos. O que consideramos relevante foi o fato de que todos os pacientes operados morreram sem disfagia. Com isso, concluímos que os pacientes tratados com esofagectomia têm beneficio tanto na sobrevida quanto na qualidade de vida para paliação da disfagia. 


\section{Retalho de Músculo Gastrocnêmio para Cobertura de Defeito de Perna Proximal}

\section{Furtado EF, Brito LL, Cavalcante H de C, Figueiredo DN de, Chacon Neto $\mathrm{O}$ de $\mathrm{H}$ Centro Paraibano de Ciências Ortopédicas - João Pessoa (PB), Brasil}

Introduçáo: Devido a modernas técnicas de cirurgia com preservação de membros, as reconstruçóes ósseas são frequentemente realizadas nos tumores dessa localização. Após ressecçóes destes, a cobertura de partes moles não é satisfatória, sendo a rotação de retalho da parte medial do Músculo Gastrocnêmio (RMMG) uma solução. Esse procedimento consegue cobrir uma área correspondente a $60 \mathrm{~cm}^{2}$, com o mínimo de dano estético e não levando a prejuízos funcionais de flexão do tornozelo e do joelho. Objetivo: Demonstrar a possibilidade de realizar cobertura de perna proximal com a realização de RMMG. Material e Métodos: Vinte e dois pacientes foram submetidos à rotação de RMMG para cobertura do terço proximal da perna. A idade média dos pacientes foi de 22,1 anos. O diagnóstico mais frequente foi de osteossarcoma. Em dez pacientes, foi realizado fechamento primário da ferida e em 12 fechamento secundário, sendo oito por segunda intenção e quatro por cobertura com enxerto livre de pele. Resultados: $\mathrm{O}$ retalho foi suficiente para a cobertura dos defeitos e obteve fechamento cutâneo em 100\% dos casos. Ocorreram duas infecçóes e um caso de necrose. Não foi evidenciada dor tardia. Edema temporário foi observado em oito pacientes. Evidenciadas duas solturas do mecanismo extensor do joelho. $\mathrm{O}$ aumento médio do tempo cirúrgico foi de 30 minutos, não leva a sangramentos importantes e possibilita uma ancoragem biológica do tendão patelar. Conclusáo: A preservação funcional do membro é possível, e a cobertura com retalho muscular deve ser feita para minimizar os riscos de complicaçóes de deiscências. $\mathrm{O}$ aumento do tempo cirúrgico e do sangramento é mínimo.
Biópsia Percutânea: Resultado de Avaliação de 285 Casos

Furtado EF, Brito LL, Cavalcante H de C, Figueiredo DN de, Chacon Neto $\mathrm{O}$ de $\mathrm{H}$ Centro Paraibano de Ciências Ortopédicas - João Pessoa (PB), Brasil

Introdução: Biópsias por agulha oferecem menor contaminação dos tecidos moles por células tumorais, menor morbidade pós-operatória e menor exposição dos tecidos circunjacentes em relação a biópsias incisionais. Indicamse em lesōes ósseas agressivas e nas de difícil diagnóstico. Objetivam confirmar a hipótese diagnóstica com mínimos resultados falso-negativos e menor índice de complicaçóes. Objetivo: Avaliar resultados da realização de biópsia percutânea por agulha de tecido ósseo e de partes moles de extremidade, e percentual de complicaçóes. Metodologia: Avaliaram-se 285 prontuários de pacientes submetidos à biópsia percutânea (agulhas de punção), realizadas entre maio de 2003 e abril de 2009 . Lesóes localizadas em esqueleto apendicular, submetidas a estadiamento radiológico pré-operatório. Idade média de 24,06 anos. Todos os procedimentos realizados pelo mesmo cirurgião e princípios oncológicos respeitados. Realizada incisão longitudinal de 0,5 centímetro de comprimento, dissecção romba com pinça delicada e introduzida agulha para perfurar lesão, retirando fragmentos, armazenados em solução de formaldeído. Exames anatomopatológicos realizados pelos mesmos patologistas. Um segundo procedimento realizado em sete pacientes, sendo incisional em dois. Um paciente submetido a três biópsias percutâneas. Em três pacientes, mudou-se diagnóstico após segunda biópsia. Resultados: Avaliação obtida comparandose hipótese diagnóstica, formulada com história clínica e dados dos exames de imagem, com diagnóstico obtido com anatomopatológico. Em 2,45 \% dos casos repetiu-se o exame. Resultado falso-negativo em 2,1\%; falso-positivo em $0,35 \%$. Complicaçóes registradas: infecçâo superficial em dois, equimose em seis e ulceração em quatro pacientes. Conclusáo: A biópsia percutânea é procedimento barato, simples e apresenta baixo índice de complicaçóes e de resultados falso-negativos. É necessário, porém, uma equipe sincronizada de ortopedistas, patologistas e radiologistas. 